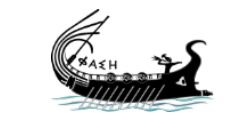

journal.phaselis.org
PHAS $\angle L I S$

Volume II (2016)
Disiplinlerarası Akdeniz Araştırmaları Dergisi

Journal of Interdisciplinary Mediterranean Studies

\title{
Phaselis Antik Kenti Florası II
}

\section{Flora of the Ancient City of Phaselis II}

\author{
R. Süleyman GÖKTÜRK
}

open access journals

PHASELIS: Disiplinlerarası Akdeniz Araştırmaları Dergisi'nde bulunan içeriklerin tümü kullanıcılara açık, serbestçe/ücretsiz "açık erişimli" bir dergidir. Kullanıcılar, yayıncıdan ve yazar(lar)dan izin almaksızın, dergideki makaleleri tam metin olarak okuyabilir, indirebilir, dağıtabilir, makalelerin çıktısını alabilir ve kaynak göstererek makalelere bağlantı verebilir.

PHASELIS: Disiplinlerarası Akdeniz Araştırmaları Dergisi uluslararası hakemli elektronik (online) bir dergi olup değerlendirme süreci biten makaleler derginin web sitesinde (journal.phaselis.org) yıl boyunca ilgili sayının içinde (Volume II: Ocak-Aralık 2016) yayımlanır. Aralık ayı sonunda ilgili yıla ait sayı tamamlanır.

Dergide yayımlanan eserlerin sorumluluğu yazarlarına aittir.

Atıf Düzeni R. S. Göktürk, “Phaselis Antik Kenti Florası II”. Phaselis II (2016) 57-101.

DOI: 10.18367/Pha.16005

Geliş Tarihi: 02.01.2016 | Kabul Tarihi: 12.06.2016 | Online Yayın Tarihi: 22.06.2016

Editörya Phaselis Research Project

www.phaselis.org 


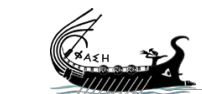

journal. phaselis.org

\title{
Phaselis Antik Kenti Florası II
}

\section{Flora of the Ancient City of Phaselis II}

\author{
R. Süleyman GÖKTÜRK*
}

Öz: Bu çalışmada 2012 yılında başlayan ve ilk aşaması beş yıl sürecek olan projenin üçüncü ve dördüncü yıllarında (2014 ve 2015) tespit edilen bitkiler ve genel özellikleri verilmiştir. 2014 ve 2015 yılında çalışma alanından toplanan bitkilerin teşhis edilmesiyle 61 familya'ya ait 168 cins ve toplam 203 takson tespit edilmiştir. Ayrıca dört yıl boyunca teşhis edilen bitkiler ile ilgili toplam veriler de sonuç ve tartışma bölümünde verilmiştir.

Anahtar sözcükler: Phaselis · Antalya · Bitkiler · Endemik · Pteridophyta · Magnoliophyta · Magnoliopsida - Pinophytina · Liliopsida

Abstract: This study presents the plant species found within the third and the fourth year (2014 and 2015) of the project which began in 2012 and is planned to last five years; together with the general features of these plants. The plants collected from the research field in 2014 and 2015 have been identified; 168 species belonging to 61 families and a total of 203 taxons have been determined. The total data related to the plants determined within four years of the project are given in the conclusion and discussion parts of this study.

Keywords: Phaselis · Antalya · Plants - Endemic · Pteridophyta · Magnoliophyta - Magnoliopsida - Pinophytina - Liliopsida

\section{Giriş}

"Phaselis Antik Kenti Florası I" isimli makalede ülkemizin, Antalya'nın ve Olimpos-Beydağları sahil Milli Parkının floristik zenginliği hakkında genel bilgiler, çalışmanın materyal ve metodu, bulguların hangi sıra ile verildiğine dair bilgiler ve kullanılan kısaltmalar verilmişti (Göktürk 2015). Bu nedenle tüm bu bilgiler bu makalede tekrar edilmemiştir. Bu makalede, birinci makalede verilen bitkilere ilave olarak, 2014 ve 2015 yıllarında toplanan ve teşhisi yapılan 61 familya'ya ait 168 cins ve toplam 203 takson ve bu taksonlara ait kısa açıklayıcı özellikleri verilmiştir. Tespit edilen bu 203 taksonun 139 tanesi tür, 42 tanesi alt tür ve 22 tanesi ise varyete düzeyindedir. Bu 203 taksonun 32 tanesi endemiktir. Bu 32 endemik taksonun 1 tanesi Olimpos-Beydağları Milli Parkı endemiği, 8 tanesi Antalya endemiği ve 23 tanesi de Türkiye endemiğidir. 203 taksonun 88 tanesi Akdeniz Fitocoğrafik Bölgesi elementi, 10 tanesi İran-Turan Fitocoğrafik Bölgesi elementi, 8 tanesi Avrupa-Sibirya Fitocoğrafik Bölgesi elementi ve 97 tanesi ise Çok Bölgeli veya Fitocoğrafik Bölgesi bilinmeyendir. Bu dönemde teşhis edilen 203 taksonun 2 tanesi Pteridophyta (Eğreltiler) şubesine, 201 takson ise Magnoliophyta (Tohumlu bitkiler) şubesine aittir. Pinophytina (Açık tohumlular) alt şubesinde 1, Magnoliophytina (Kapalı tohumlular) alt şubesinde ise 200 takson

* Prof. Dr., Akdeniz Üniversitesi, Fen Fakültesi, Biyoloji Bölümü, Antalya. gokturk@akdeniz.edu.tr 
yer almaktadır. Magnoliophytina (Kapalı tohumlular) alt şubesinde yer alan 200 taksonun 169 tanesi Magnoliopsida (Dikotiller) sınıfına, 31 tanesi ise Liliopsida (Monokotiller) sınıfına aittir.

Bulgular

Şube: Pteridophyta (Eğreltiler)

Familya: Aspleniaceae (Saçakotugiller)

Asplenium onopteris L. (Kalkaneğreltisi)

Kümeli, 10-25 cm boyunda yapraksı gövdeli bitkiler. Yapraksı gövde lamina 2 pinnat parçalı, sap genellikle laminadan uzun, uç segmentler mızraksı veya şeritsi, uç kısımda genellikle kılçıksı. Spor keseleri uzun. 500 m'ye kadar olan yüksekliklerdeki gölgeli kayalıklar ve duvarda yetişen bu türün sporları Temmuz-Ağustos ayında çiçeklenir. ÇBFCB.

Familya: Pteridaceae (Baldırıkaragiller)

Adiantum capillus-veneris L. (Baldırıkara) (Fig. 1)

Sürünücü rizomlu bitkiler. Yapraksı gövde 10-40 $\mathrm{cm}$ boyunda, 2 pinnat parçalı, uç segmentleri ince. Spor keseleri yaprak kenarlarının loplarında kıvrılmış durumda. Sporları Ocak-Ekim aylarında olgunlaşan bu eğrelti, 800 m'ye kadar olan yüksekliklerdeki kireç taşlı kayalık yarıklarında ve besince zengin topraklarda yetişir. ÇBFCB.

\section{Şube: Magnoliophyta (Tohumlu Bitkiler)}

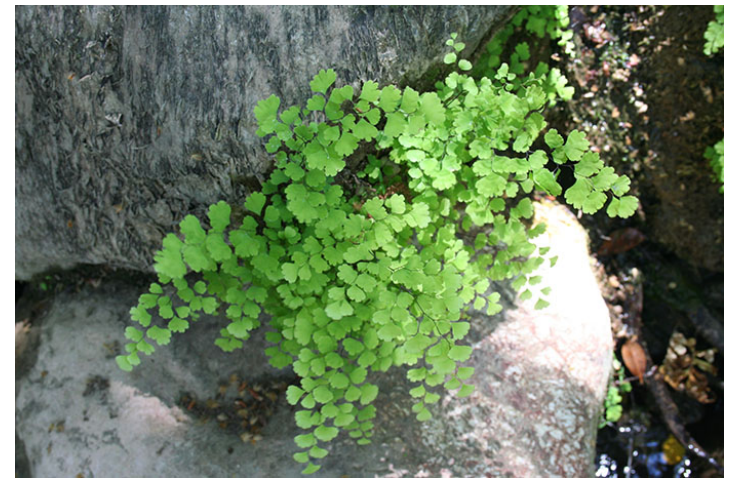

Fig. 1. Adiantum capillus-veneris

Altşube: Pinophytina (Açık Tohumlular)

\section{Altsınıf: Pinidae}

Familya: Cupressaceae (Servigiller)

Juniperus excelsa M.Bieb. subsp. excelsa (Boz Ardıç)

20 m'ye kadar boylanabilen ağaçlar. Gövde genç iken piramidal, yaşlanınca yayvan-topumsu tepeli. Olgun yapraklar üçgenimsi. Erkek ve dişi organlar farklı çiçeklerde, ancak aynı ağaç üzerinde. Üzümsü kozalaklar, küresel, koyu morumsu-kahve renkli, 7-12 mm çapında. Her kozalak 4-10 adet tohumlu. Bu alt tür, ülkemizde doğu Karadeniz Bölgesi hariç tüm bölgelerde, ülkemiz dışında ise Balkanlar, Kırım, Kıbrıs, Batı Suriye, İran ve Afganistan'da yayılış gösterir. Yetişme ortamı olarak ise 300-2300 m'ler arasındaki kuru kayalık yamaçları tercih eder. ÇBFCB.

\section{Altşube: Magnoliophytina (Kapalı Tohumlular)}

\section{Sınıf: Magnoliopsida (Dikotiller)}

Familya: Amaranthaceae (Horozibiğigiller)

\section{Chenopodium album L. subsp. album var. album (Aksirken)}

20-150 cm boyunda, bir yıllık otsu bitkiler. Yapraklar yumurtamsı-mızraksı. Brakteol mevcut değil. Periyant segmentleri 3-5 parçalı, yeşil veya membranımsı. Mayıs-Ağustos aylarında çiçeklenen bu varyete, 2000 m'ye kadar olan yüksekliklerdeki nemli yerlerde ve kültür alanlarında yetişir. ÇBFCB. 
Familya: Apiaceae (Maydanozgiller)

\section{Artedia squamata L. (Karabenek)}

Bir yıllık otsu bitkiler. Gövde dik, dallı ve çıplak. Yapraklar 3-pinnat parçalı, kılsı. Petaller beyaz renkli. Meyve 6-8 mm boyunda, kaşıksı. Ülkemizde geniş bir yayılış alanına sahip olan bu tür, nisan-temmuz ayında çiçeklenir. Yetişme ortamı olarak deniz seviyesinden 1500 m'ye kadar olan yüksekliklerdeki tepelikleri, yamaçları, çalılıkları ve tarla kenarlarını tercih eder. ÇBFCB.

\section{Bupleurum gracile d'Urv. (Şeytanyıldızı)}

5-50 cm boyunda bir yıllık otsu bitkiler. Yapraklar şeritsi. Rays eşit boyda değil. Brakte 3-7 mm boyunda. Brakteol 5 adet, eliptikten yumurtamsıya kadar değişen şekillerde. Petaller sarı renkli. Ülkemizde Ege ve Akdeniz bölgelerinde yayılış gösteren bu tür, Nisan ve Mayıs aylarında çiçeklenir. Yetişme ortamı olarak ise deniz seviyesinden 1000 m'ye kadar olan yüksekliklerdeki kurak yerleri, açık alanları ve kalkerli toprak alanları tercih eder. Akd. El.

\section{Eryngium bourgatii Gouan subsp. heldreichii (Boiss.) P.H.Davis (Gelenkuş)}

15-45 cm boyunda çok yıllık otsu bitkiler. Taban yaprakları elsi parçalı; segmentler şeritsi-biz biçimli dikenli loplu. Brakteler 7-12 adet, şeritsi-mızraksı. Çiçekler mavimsi veya beyazımsı renkli. Meyve hemen hemen yumurtamsı. Ülkemizde Antalya, Muğla, Isparta, Konya ve Mersin illerinde, ülkemiz dışında ise Lübnan'da yayılış gösteren bu alt tür, Temmuz-Ağustos aylarında çiçeklenir. Yetişme ortamı olarak ise 1520-2400 m’ler arasındaki kireçtaşlı kayalık yamaçları tercih eder. D. Akd.(Dağ) El.

\section{Cachrys crassiloba (Boiss.) Meikle (Çarşambaotu)}

Kalın ve tüysüz gövdeli çok yıllık bitkiler. Yapraklar 3-ternat. Üst gövde yapraklarının hepsi mızraksı ve basit. Brakteoller şeritsi-mızraksı. Petaller sarı renkli. Meyve sert dikenli. Ülkemizde Antalya ve Muğla illerinde, ülkemiz dışında ise sadece Kıbrıs Adası'nda yayılış göstermektedir. Yetişme ortamı olarak deniz seviyesinden 800 m'ye kadar olan yüksekliklerdeki uçurumları ve kızılçam altlarını tercih eden bu tür, Temmuz ve Ağustos aylarında çiçeklidir. ÇBFCB.

\section{Scandix pecten-veneris L. (Zühretarağı)}

Hemen hemen dik gövdeli, 6-35 cm boyunda bir yıllık otsu bitkiler. Yapraklar dikdörtgenimsiden dikdörtgenimsi-yumurtamsıya kadar değişen şekillerde, pinnatisekt parçalı. Çiçekler beyaz renkli. Meyve 3-7.5 cm boyunda. Yetişme ortamı olarak deniz seviyesinden 980 m’ye kadar olan yüksekliklerdeki kireçtaşı kayalık yamaçları, yol kenarları, çam ormanlarını ve tarla kenarlarını tercih eden bu türün çiçeklenme zamanı ise Mart-Haziran aylarıdır. ÇBFCB.

\section{Tordylium apulum L. (Kafkalida)}

Yumuşak veya sert tüylü, dallı, $10-50 \mathrm{~cm}$ boyunda bir yıllık otsu bitkiler. Taban ve gövde yaprakları pinnat parçalı; segmentler yumurtamsı-yuvarlak. Brakte ve brakteol 3-6 adet, şeritsi. Çiçekler beyaz renkli. Merikarp meyve eliptikten dairesele kadar değişen şekillerde. Bu tür, Nisan ve Mayıs aylarında çiçeklenir ve 5-550 m'ler arasındaki kayalık tepelikleri, açık alanları ve yol kenarlarını yetişme ortamı olarak tercih eder. Akd. El. 


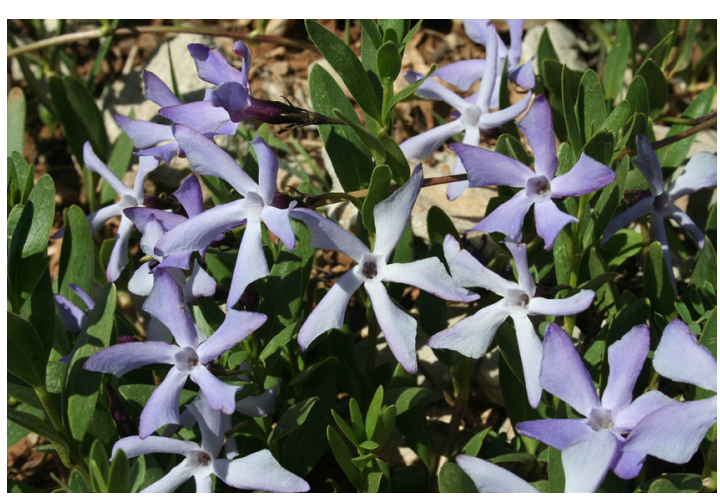

Fig. 2. Vinca herbacea
Familya: Apocynaceae (Zakkumgiller)

Vinca herbacea Waldst. \& Kit. (Bikir Çiçeği) (Fig. 2)

Otsu çok yıllık otsu bitkiler. Eğik tırmanışlı sürgün $20 \mathrm{~cm}$, sürünücü sürgün ise $60 \mathrm{~cm}$ 'ye kadar boylanır. Yapraklar dökülücü, eliptik, mızraksıdan eliptiğe kadar değişen şekillerde. Kaliks 3-10 mm boyunda. Korolla soluk maviden mor-mavi renkli. Mart-Mayıs ayında çiçeklenen bu tür, 400-2000 m’ler arasındaki güneşli açık yamaçları, kayalıkları, çalııkları ve orman açıklıklarını tercih eder. ÇBFCB.

\section{Familya: Aristolochiaceae (Lohusaotugiller)}

Aristolochia hirta L. (Yılanotu) (Fig. 3)

Toprak altı gövdesi silindirik. Gövde dik, sert kıllı tüylü, 15-50 cm boyunda çok yıllık otsu bitkiler. Yapraklar üçgenimsiden yumurtamsı-üçgenimsiye kadar değişen şekillerde. Periyant grimsi-kahve renkli; tüp $U$ şeklinde, dudaklar yumurtamsı ve uzun beyaz tüylü. Kapsül meyve elipsiod-dikdörtgenimsi. Ege ve Akdeniz bölgelerimizde yayııış gösteren bu tür, Mart-Haziran aylarında çiçeklenmekte olup yetişme ortamı olarak ise deniz seviyesinden 1200 m'ye kadar olan yüksekliklerdeki taşıık alanları, üzüm bağlarını, çam ormanlarını ve gölgelik alanlarını tercih eder. Akd. El.

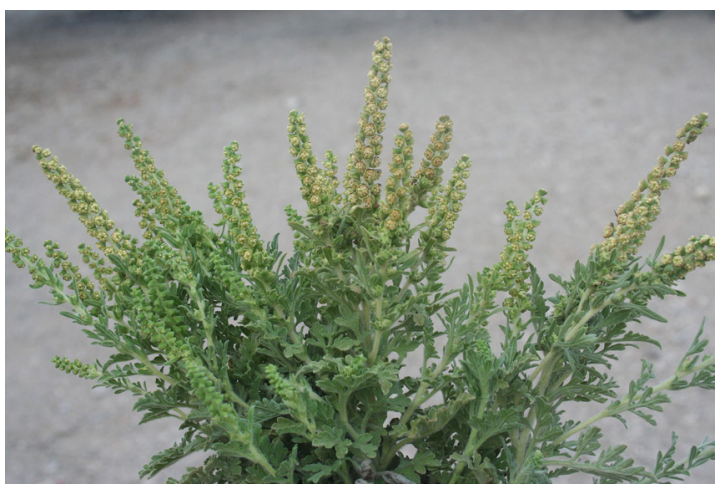

Fig. 4. Ambrosia maritima

Akdeniz sahillerinde yaylış göstermektedir. Akd. El.

Anthemis rosea Sm. subsp. carnea (Boiss.) Grierson (Gül Papatya) (Türkiye Endemiği) (Fig. 5)

Dik veya kalkık uçlu, 20 cm'ye kadar boylanabilen, bir yıllık otlar. Gövde basit veya tabanda dallı. Yapraklar 2-3 pinnatisekt parçalı. Dilsi çiçekler pembemsi, tüpsü çiçekler sarı renkli. Aken meyve

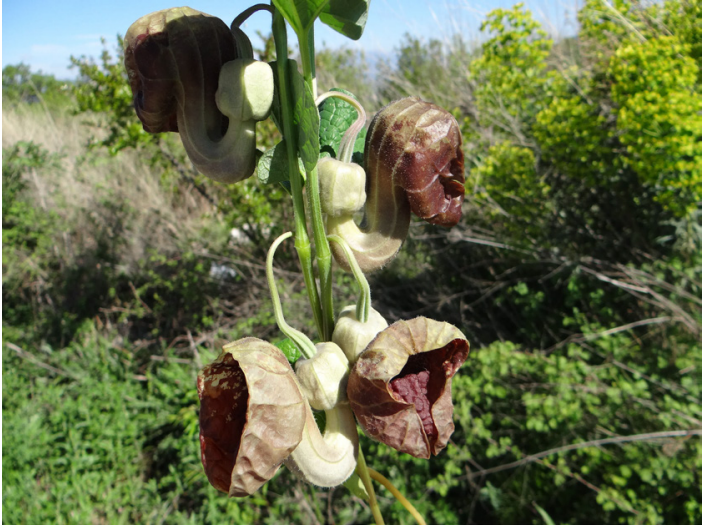

Fig. 3. Aristolochia hirta

Familya: Asteraceae (Papatyagiller)

Ambrosia maritima L. (Zaylan Çiçeği) (Fig. 4)

Çok yıllık yarı çalılar. Gövde 100 cm'ye kadar boylanır. Yapraklar basit loplu-pinnatisekt. Erkek kapitula $3 \mathrm{~mm}$ eninde. Dişi kapitula yaprak koltuklarında grup halinde. Aken meyve küresel ve tüysüz. Bu tür yetişme ortamı olarak, deniz seviyesinden 500 m'ye kadar olan sahildeki kumul alanları ve açık alanları tercih etmekte olup, Ağustos-Aralık ayları arasında çiçeklenmektedir. Ülkemiz dışında, doğu, Güney-Doğu ve Kuzey 
1.75-2.25 mm boyunda. Ülkemize özgü olan bu alt tür, 50-1770 m'ler arasındaki kireçtaşı kayalıkları ve yamaçları tercih eder. Çiçeklenme zamanı ise Mart-Haziran aylarıdır. Akd. El.

\section{Carduus argentatus L. (Gümüş Dikeni)}

40 cm'ye kadar boylanabilen, narin yapılı bir yıllık otlar. Gövde yaprakları pinnatifid parçalı. Çiçekler mor-pembe renkli. Meyve aken, $5 \mathrm{~mm}$ boyunda. illk kez Mısır'dan toplanarak 1771 yılında bilim dünyasına tanıtılan bu tür, MayısHaziran aylarında çiçeklenir. Bu bitki yetişme or-

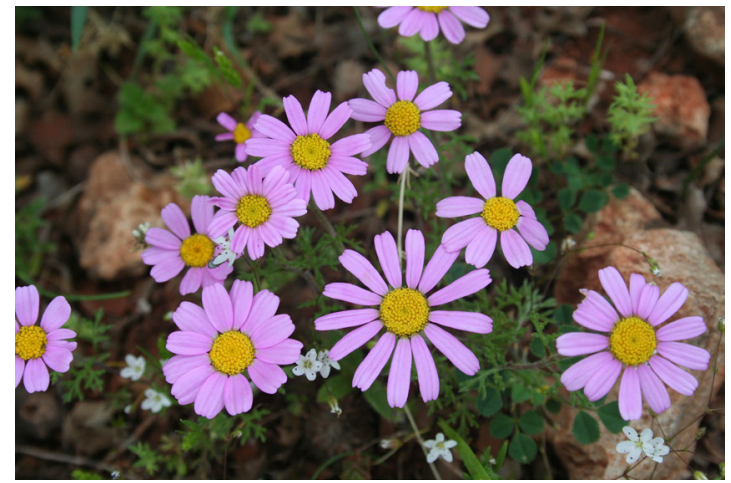

Fig. 5. Anthemis rosea subsp. carnea tamı olarak, 100-760 m'ler arasındaki kayalık kireçtaşı tepelerini tercih etmektedir. Akd. El.

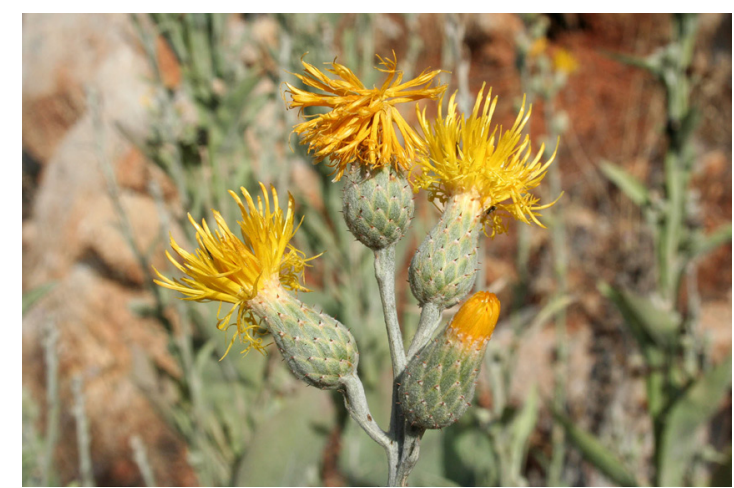

Fig. 6. Centaurea babylonica

\section{Centaurea babylonica (L.) L. (Salkım Sarıbaş)} (Fig. 6)

3 m'ye kadar boylanabilen iki yıllık otsu bitkiler. Alt yapraklar lirat parçalı. Kapitula hemen hemen sapsız. Çiçekler sarı renkli. Aken meyve 4.5$5.5 \mathrm{~mm}$. Bu tür yetişme ortamı olarak 200-1100 m'ler arasındaki çam ormanlarını, maki ve tarla kenarlarını tercih eder. Ülkemizde özellikle Akdeniz Bölgesi'nde yayılış gösteren bu salkım Sarıbaş, ülkemiz dışında ise Filistin ve Lübnan'da yayılış göstermektedir. Türün çiçeklenme zamanı Haziran-Ağustos ayları'dır. Akd. El.

Centaurea drabifolia Sm. subsp. cappadocica (DC.) Wagenitz (Peri Sarıbaş) (Türkiye Endemiği)

15 cm'ye kadar boylanabilen çok yıllık otsu bitkiler. Yapraklar seyrek keçemsi tüylü, mızraksıdan şeritsi-mızraksıya kadar değişen şekillerde. Çiçekler sarı renkli. Aken meyve 5-6 mm boyunda. Ülkemize özgü olan bu peygamber çiçeği, Haziran-Ağustos aylarında çiçeklenir. Bu alt tür yetişme ortamı olarak 1300-1600 m'ler arasındaki kayalıkları ve kayalık yamaçları tercih eder. ÇBFCB.

\section{Centaurea pestalozzae Boiss. (Bodur Sarıbaş)} (Antalya Endemiği) (Fig. 7)

Çok yıllık gövdesiz veya çok kısa gövdeli bitkiler. Yaprakların hepsi tabanda, pinnatisekt parçalı, sert dikensi tüylü. Çiçekler beyazımsı, turuncu çizgili. Aken meyve 7-7,5 mm boyunda. Antalya iline özgü olan bu bodur sarıbaş, yetişme ortamı olarak 1270-2300 m'ler arasındaki taşlık yamaçları tercih eder. Çiçeklenme zamanı ise Haziran-Temmuz aylarıdır. Akd. El.

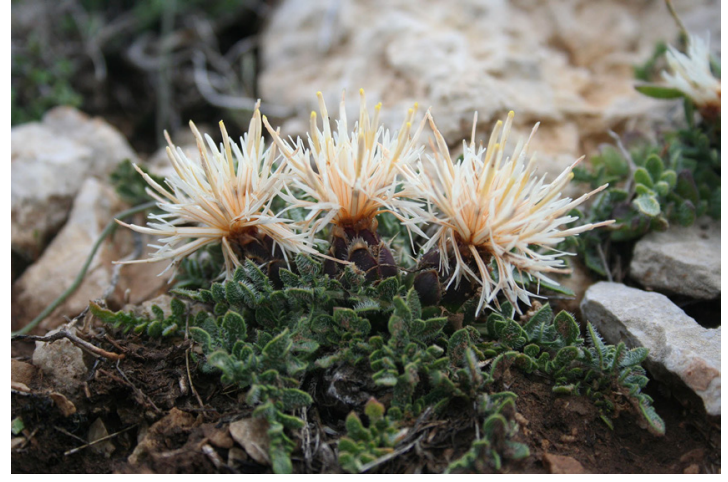

Fig. 7. Centaurea pestalozzae 


\section{Cnicus benedictus L. (Topdiken)}

35 cm'ye kadar boylanabilen bir yıllık otsu bitkiler. Alt yapraklar dikdörtgenimsi-mızraksı. Çiçekler sarı renkli, involukrumdan kısa. Meyve aken. Bu tür Nisan-Haziran aylarında çiçeklenir. Yetişme ortamı olarak ise 70-1580 m'ler arasındaki, çalııkları, stebi, tepelikleri ve yol kenarlarını tercih eder. ÇBFCB.

\section{Crupina crupinastrum (Moris) Vis. (Gelindöndüren)}

Narin yapılı, bir yıllık bitkiler. Gövde dik, $19-80 \mathrm{~cm}$ boyunda. Yapraklar sapsız, pinnatisekt parçalı. Çiçekler kımızı veya mor renkli. Aken meyve ters yumurtamsı. Bu tür yetişme ortamı olarak 1001400 m'ler arasındaki kızılçam açıkıklarını, stebi ve kayalık kireçtaşı kayalıklarını tercih etmekte olup Nisan-Haziran aylarında çiçeklenir. ÇBFCB.

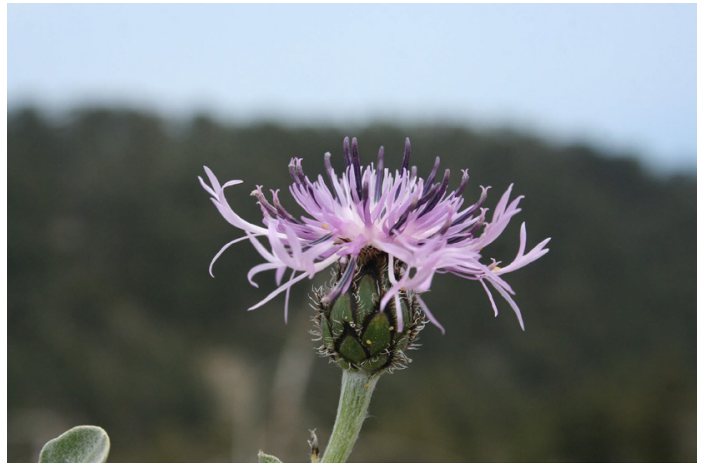

Fig. 8. Cyanus bourgaei

Cyanus bourgaei Boiss. (Kel Gökbaş) (Antalya Endemiği) (Fig. 8)

Eğik tırmanışlı, çok yıllık otsu bitkiler. Kökler kısmen kalınlaşmış, rizom bir rozet yaprakla sonlanır, rozetlerin tabanında birkaç çiçekli gövde bulunur. Yapraklar lirat parçalı, basık keçemsi tüylü; uç segmentler mızraksı. Çiçekler menekşe, mor veya sarımsı beyaz renkli. Ülkemize özgü olan bu tür, sadece Antalya ilinde yetişmektedir. NisanHaziran aylarında çiçeklenen bu bitki yetişme ortamı olarak 1100-2200 m’ler arasındaki kayalık yamaçları, çalıık alanları ve sedir açıkıklarını tercih eder. Akd. El.

\section{Echinops emiliae P. H. Davis (Koca Topuz) (Türkiye Endemiği) (Fig. 9)}

Sağlam yapılı çok yıllık otsu bitkiler. Gövde dik, 40-60 cm boyunda, basit veya üst kısımda dallanmış. Alt yapraklar kısa saplı, pinnatifid parçalı. Kafalar 12-15 cm çapında. Çiçekler soluk yeşil renkli. Akenler dikdörtgenimsi-silindirik. Yetişme ortamı olarak 1600-2200 m’ler arasındaki kireçtaşı kayalıklarını tercih eden bu tür, ülkemize özgü olup, sadece Antalya ve Muğla illerinde yayılış gösterir. Haziran-Temmuz aylarında çiçek açar. Akd. El.

\section{Glebionis segetum (L.) Fourr. (Kasım Çiçeği)}

70 cm'ye kadar boylanabilen bir yıllık otlar. Gövde dik ve dallı. Yaprak pinnatisekt parçalı. Dilsi çiçekler sarı renkli ve 10-15 tane. Tüpsü çiçekler altın sarısı renkli. Aken meyve dikdörtgenimsi-topaçsı. Bu tür yetişme ortamı olarak deniz seviyesinden başlayarak 1250 m'ye kadar yol kenarları, mısır tarlaları ve kayalık yerleri tercih eder. Çiçeklenme zamanı ise Mart-Haziran aylarında çiçeklenir. ÇBFCB.

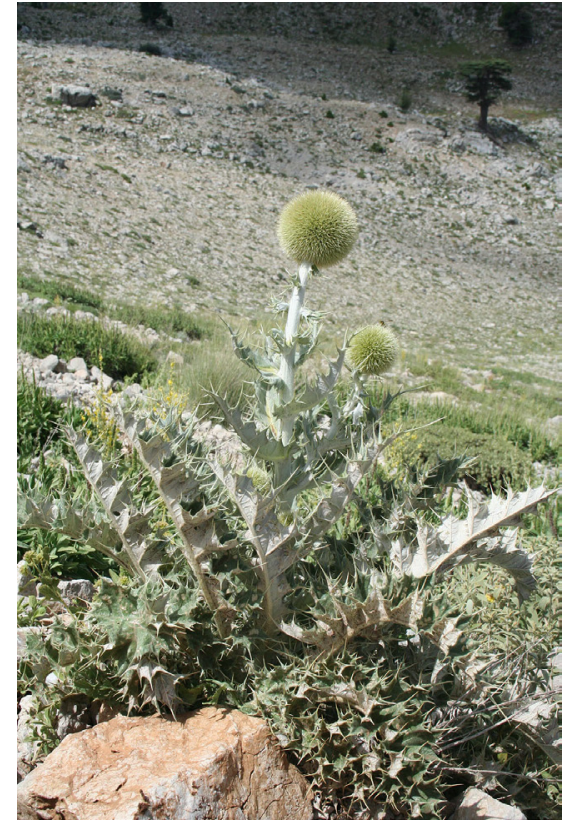

Fig. 9. Echinops emiliae 


\section{Hieracium pannosum Boiss. (Acıkanak)}

60 cm'ye kadar boylanabilen tüylü çok yıllık bitkiler. Yapraklar gövdenin alt kısmında kümelenmiş, ters mırraksı-dikdörtgenimsi, ters mızraksı veya ters yumurtamsı. Çiçekler sarı renkli. Aken meyve sarımsı-kahverengi. Ülkemiz dışında, Balkanların kuzey kesimleri, Bulgaristan ve Kafkasya'da yayılış göstermektedir. Yetişme ortamı olarak 1000-2700 m'ye kadar olan yüksekliklerdeki kalkerli kayalıkları ve orman açıklıklarını tercih eder. Akd. El.

\section{Inula viscosa (L.) Aiton (Sümenit) (Fig. 10)}

Yapışkan, 1 m'ye kadar boylanabilen çalımsı bitkiler. Yapraklar mızraksı veya ters mızraksı. Çiçekler sarı renkli. Aken meyve tüylü. HaziranKasım aylarında çiçeklenen bu tür, yetişme ortamı olarak deniz seviyesinden başlayarak 800 m'ye kadar olan yüksekliklerdeki tepelik alanları, nemli yerleri, yol kenarlarını ve bataklık alanları tercih eder. Akd. El.

Lactuca intricata Boiss. (Güzel Merhemotu) (Fig. 11)

Kalın köklere sahip çok yıllık otsu bitkiler. Gövde 5-45 cm boyunda, çıplak nadiren tüylü, karışık dallı. Yapraklar çoğunlukla tabanda. Çiçekler lavanta mavi veya leylak renkli. Aken meyve 8-13 mm boyunda. Bilim dünyasına ilk kez Denizli'den tanıtılan bu tür, ülkemiz dışında Yunanistan ve Arnavutluk'ta yayılış göstermektedir. Yetişme ortamı olarak ise 1100-2450 m'ler arasındaki kayalık yamaçları ve kalkerli toprakları tercih eder. D. Akd. (dağ) El.

Notobasis syriaca (L.) Cass. (Yavan Kenger) (Fig. 12)

Dik gövdeli 120 cm'ye kadar boylanabilen, dikenli bir yıllık otsu bitkiler. Yapraklar basit veya pinnatifid parçalı, eliptik. Çiçekler pembe veya mor renkli. Aken meyve basık-ters yumurtamsı. Ülkemiz dışında kuzey Irak, Kuzey Batı İran ve Azerbaycan'da yayılış gösteren bu bitki, Nisan-Haziran aylarında çiçeklenir. Yetişme ortamı olarak ise deniz seviyesinden başlayarak 850 m'ye kadar olan yüksekliklerdeki kireçtaşlı kayalık ya-

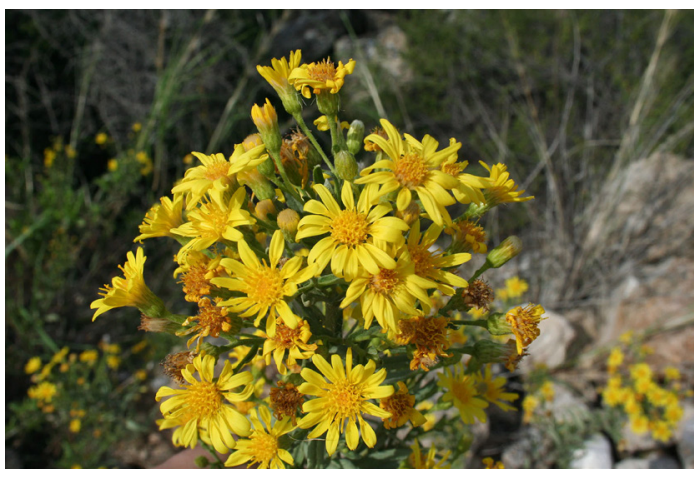

Fig. 10. Inula viscosa

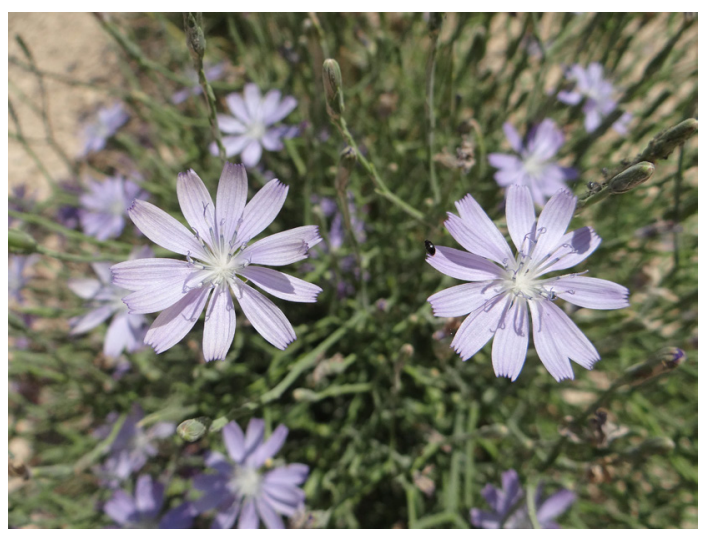

Fig. 11. Lactuca intricata

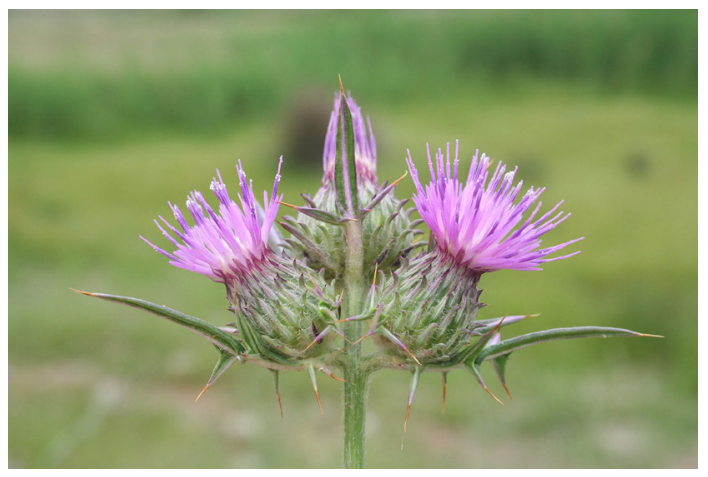

Fig. 12. Notobasis syriaca maçları, tarlaları ve yol kenarlarını tercih eder. Akd. El.

\section{Scorzonera elata Boiss. (Çetotu)}

Dik, dallı, 120 cm'ye kadar boyanabilen çok yıllık otlar. Alt yapraklar şeritsi. Çiçekler sarı renkli. Aken meyve silindirik. İlk kez Manisa-Spil Dağ'ından toplanarak bilim dünyasına tanıtılan bu tür, 
Mayıs-Haziran aylarında çiçeklenir. Bu tür, yetişme ortamı olarak deniz seviyesinden başlayarak 1600 m’ye kadar olan yüksekliklerdeki deniz kayalıkları ve kalkerli toprakları tercih eder. Akd. El.

Tanacetum argenteum (Lam.) Willd. subsp. canum (C. Koch) Grierson var. pumilum Grierson (Antalya Endemiği)

Kümeli çok yıllık otsu bitkiler. Gövdeler 20-30 cm boyunda, gümüşi veya beyaz-keçemsi tüylü. Alt yapraklar basit veya parçalı. Çiçekler sarı renkli. Aken meyve kahverengi. Bu varyete sadece Antalya ilinde, Bozburun ve Tahtalı Dağlarında yetişmektedir. Çiçeklenme zamanı Haziran-Ağustos ayları olan bu bitki yetişme ortamı olarak ise 900-2500 m’ler arasındaki kireçtaşı yarıklarını ve kayalık yerleri tercih eder. Ir.-Tur. El.

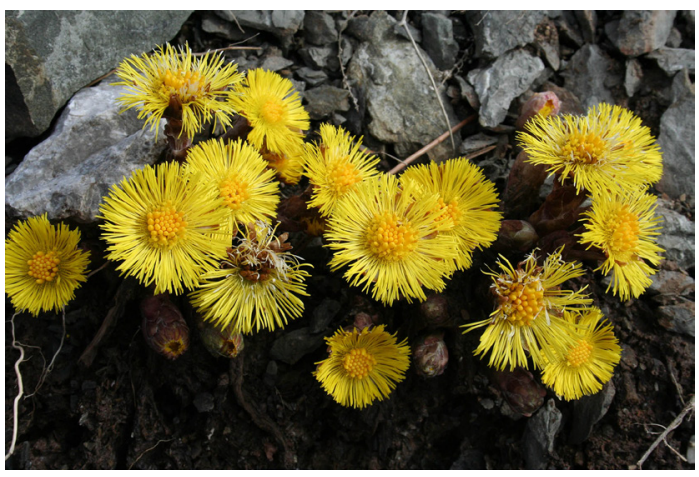

Fig. 13. Tussilago farfara
Tussilago farfara L. (Öksürük Otu) (Fig. 13)

Rizomlu çok yıllık otlar. Yapraklar saplı, aya 10-20 (-30) cm çapında, kenarları düzensiz dişli. Çiçekler sarı renkli. Aken meyve silindirik, çıplak. MartNisan aylarında çiçeklenen bu tür yetişme ortamı olarak, deniz seviyesinden başlayarak 2400 m'ye kadar olan yüksekliklerdeki nemli ve kumlu alanları tercih eder. ÇBFCB.

\section{Xeranthemum annuum L. (Kağıt Çiçeği)}

5-60 cm boyunda, beyaz keçemsi tüylü bir yıllık otlar. Yapraklar şeritsi-eliptik, sapsız ve düz ke-

narlı. Kapitula yarı küresel-yumurtamsı. İnvolukrum tüysüz. Dıştaki fillariler yumurtamsı-sivri uçlu, sarımsı renkli; içteki fillariler şeritsi-eliptik, beyazdan pembeye kadar değişen renklerde. Aken meyve dikdörtgenimsi. Haziran-Ağustos aylarında çiçeklenen bu tür, 10-1800 m'ler arasındaki çam ormanı açıkıklarında, garik kuşakta ve kayalık yerlerde yetişir. ÇBFCB.

Familya: Berberidaceae (Karamukgiller)

\section{Berberis crataegina DC. (Karamuk)}

2 m'ye kadar boylanabilen dikenli çalılar. Yapraklar dar ters yumurtamsı. Çiçek durumu yoğun kümeli, 6-15 çiçekli. Çiçekler sarı renkli. Üzümsü meyve önce kırmızı, olgunlaşınca sarı renkli. 8001500 m’ler arasındaki kayalık yerlerde yetişen bu bitki, Mayıs ve Haziran aylarında çiçeklenir. ÇBFCB.

\section{Familya: Betulaceae (Huşgiller)}

Ostrya carpinifolia Scop. (Firek) (Fig. 14)

20 m'ye kadar boylanabilen ağaçlar. Yapraklar yumurtamsı-dikdörtgenimsi, testere dişli kenarlı. Meyveli çiçek durumu yaklaşık $6 \mathrm{~cm}$ boyunda. Involukrum dikdörtgenimsi-yumurtamsı, uzun sivri uçlu. Meyve fındıksı, sarımsı-kahve renkli. Mart ve Nisan aylarında çiçeklenen bu tür, yetişme ortamı olarak 200-2135 m'ler arasındaki yaprak döken ormanlık alanları, çalııkları, çam ormanlarını ve kuru taşlık alanları tercih eder. Akd. El.

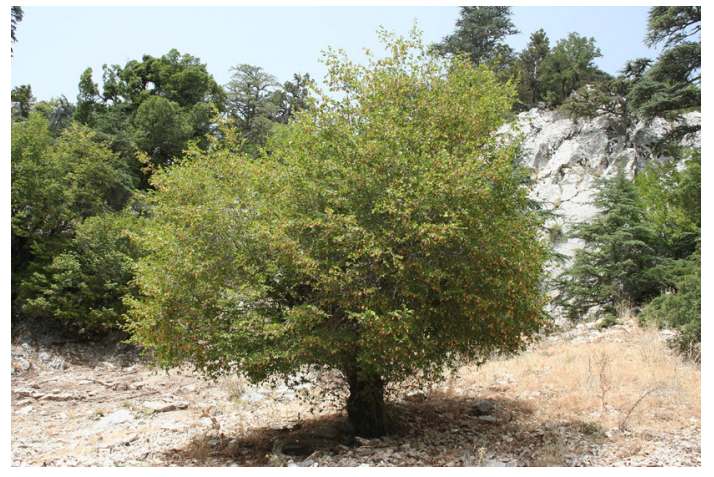

Fig. 14. Ostrya carpinifolia 
Familya: Boraginaceae (Hodangiller)

\section{Alkanna pamphylica Hub.-Mor. \& Reese} (Yaman Havaciva) (Antalya Endemiği) (Fig. 15)

$60 \mathrm{~cm}$ 'ye kadar boylanabilen çok yıllık otlar. Taban yaprakları mıraksıdan dikdörtgenimsiye kadar değişen şekillerde; gövde yaprakları yumurtamsıdan dikdörtgenimsi-mızraksıya kadar değişen şekillerde. Korolla gök mavisi renkli. Meyve fındıksı. Antalya iline özgü olan bu tür yetişme ortamı olarak 800-1700 m'ler arasındaki makilikleri, friganayı, meşelikleri ve stebi tercih eder. Çiçeklenme zamanı ise Mayıs ve Haziran ayların-

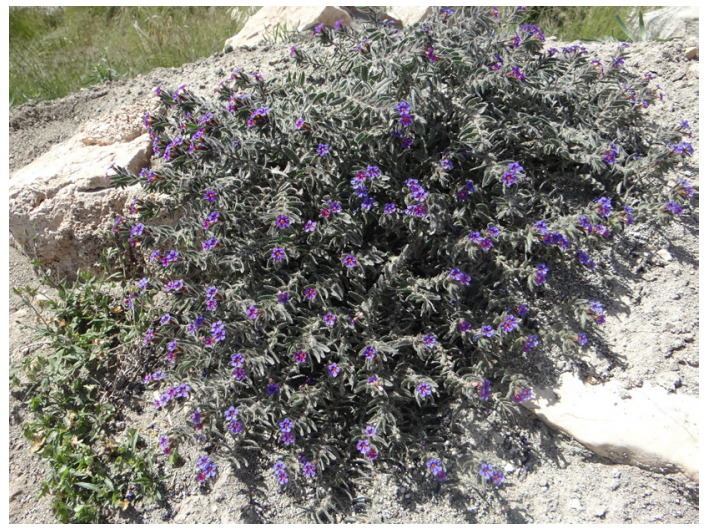

Fig. 15. Alkanna pamphylica da çiçeklenir. Akd. El.

\section{Cerinthe minor L. subsp. auriculata (Ten.) Domac (Livarotu)}

25-75 cm boyunda, dik gövdeli, iki veya çok yıllık otsu bitkiler. Taban yaprakları kaşıksıdan mızraksıya kadar değişen şekillerde. Korolla sarı, kestane, mor veya menekşe renkli. Fındıksı meyveler yumurtamsı-küresel. Bu alt tür yetişme ortamı olarak 150-2400 m’ler arasındaki yamaçları, kum yataklarını, tarla ve yol kenarlarını tercih eder. Çiçeklenme zamanı Mayıs-Ağustos aylarıdır. ÇBFCB.

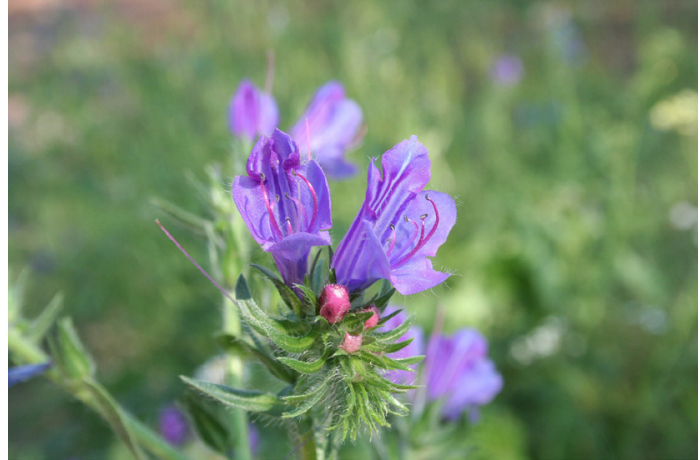

Fig. 16. Echium plantagineum

\section{Echium plantagineum L. (Kırkbatıran) (Fig. 16)}

Bir veya iki yıllık, tüylü bitkiler. Gövde genellikle tabanda dallı, 17-65 cm boyunda. Taban yaprakları yumurtamsıdan dar eliptiğe kadar değişen şekillerde. Korolla açık veya koyu maviden morumsuya kadar değişen renklerde. Mart-Eylül aylarında çiçeklenen bu kırkbatıran, yetişme ortamı olarak deniz seviyesinden başlayarak 2400 m'ye kadar olan yüksekliklerdeki tarlaları, nemli yerleri, çimenlik alanları ve kayalık yamaçları tercih eder. Akd. El.

\section{Hormuzakia aggregata (Lehm.) Guşul} (Danadili)

40 cm'ye kadar boylanabilen, sert kıllı, eğik tırmanışlı veya dik gövdeli bir yıllık otsu bitkiler. Yapraklar şeritsi-mızraksıdan darca eliptiğe kadar değişen şekillerde. Korolla mavi veya pembe renkli. Fındıksı meyve yarı küresel. Deniz kumullarını yetişme ortamı olarak tercih eden bu bitki, Mart-Eylül aylarında çiçeklenir. Akd. El.

Onosma albo-rosea Fisch. \& C. A. Mey. subsp. albo-rosea var. albo-rosea (Kaya Emceği) (Fig. 17)

10-20(-25) cm boyunda, genellikle basit, dik veya yükselici çok yıllık bitkiler. Yapraklar ters yumurtamsıdan dikdörtgenimsiye kadar değişen şekillerde veya mızraksı-kaşıksı. Korolla ilk başta beyaz renkli daha sonra mavimsi-menekşe renkli. Meyve fındıksı. Ülkemiz dışında kuzey Suriye ve Kuzey Irak'ta yayılış gösteren bu bitki, Nisan-Temmuz aylarında çiçeklenir. Yetişme ortamı olarak ise 180-2250 m'ler arasındaki kireçtaşlı kayalık yamaçları ve sarp kayalıkları tercih eder. Ir.-Tur. El. 


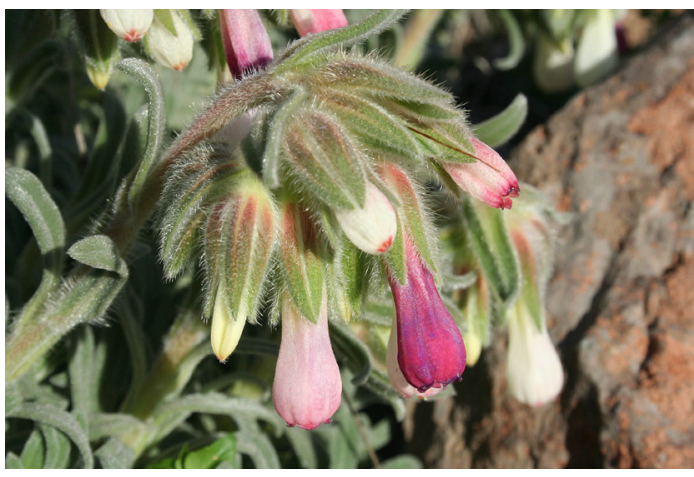

Fig. 17. Onosma albo-rosea subsp. albo-rosea var. albo-rosea
Solenanthus stamineus (Desf.) Wettst.

65 cm'ye kadar boylanabilen, dik yumuşak keçemsi tüylü çok yıllık bitkiler. Yapraklar yoğun keçemsi veya ipeksi tüylü, dar eliptikten yumurtamsıya kadar değişen şekillerde. Korolla kırmızı, kırmızımsı-mor veya mavimsi-menekşe renkli. Fındıksı meyve yumurtamsı. Ülkemizde oldukça geniş bir yayılış alanına sahip olan bu bitki, MayısAğustos aylarında çiçeklenir. Yetişme ortamı olarak ise 950-3660 m’ler arasındaki volkanik, kayalık, çimenlik yamaçları ve yol kenarlarını tercih eder. ÇBFCB.

Familya: Brassicaceae (Turpgiller)

\section{Aubrieta deltoidea (L.) DC. (Köşeli Obrizya)}

Çok yıllık otsu bitkiler. Yapraklar darca yumurtamsıdan yumurtamsıya kadar değişen şekillerde. içteki sepaller keseli. Petaller mor renkli. Meyve şişkin ve değişik tiplerde. Tüylü. Ülkemizin batı bölgelerinde yayııı̧ gösteren bu tür, ülkemiz dışında ise Sicilya, Orta Avrupa ve Balkanlarda yayıış göstermektedir. Nisan-Temmuz aylarında çiçeklenmekte olup yetişme ortamı olarak 500-210 m'ler arasındaki kayalıkları tercih eder. ÇBFCB.

Iberis carica Bornm. (Kayabeğendi) (Türkiye Endemiği) (Fig. 18)

Kısa beyaz tüylü, 3-12 cm boyunda bir yıllık otsu bitkiler. Çiçekli gövde dik. Petaller beyazdan leylak rengine kadar değişen şekillerde. Meyve yumurtamsı. Ülkemize özgü olan bu tür, Aydın, Muğla, Burdur ve Antalya illerinde yayılış göstermektedir. Yetişme ortamı olarak ise 100-2500 m'ler arasındaki kayalık yamaçları ve taşık alanları tercih eder. Akd. El.

\section{Lepidium draba L. (Diğnik)}

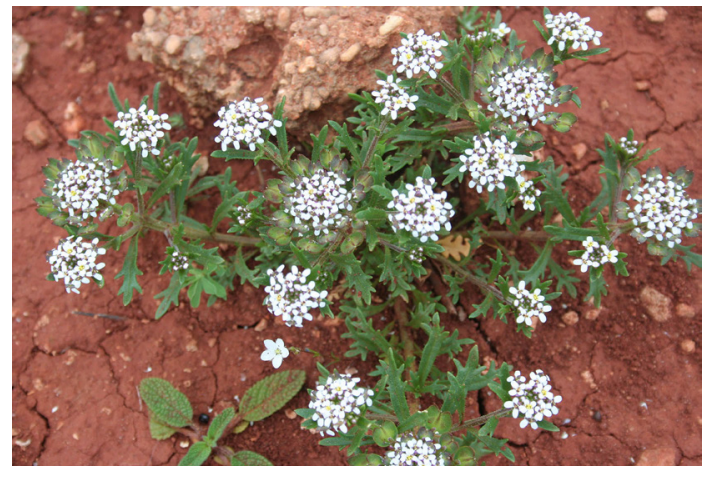

Fig. 18. Iberis carica

Stolonlu çok yıllık otlar. Çiçekli gövde çok sayıda ve çok dallı. Taban yaprakları ters yumurtamsıkaşıksı; gövde yaprakları dikdörtgenimsiden dikdörtgenimsi-mızraksıya kadar değişen şekillerde. Petaller beyaz. Meyve yumurtamsıdan kalpsiye kadar değişen şekillerde. Nisan-Mayıs aylarında çiçeklenen bu tür, yetişme ortamı olarak deniz seviyesinden başlayarak 1300 m'ye kadar olan yüksekliklerdeki kültür alanlarını tercih eder. ÇBFCB.

\section{Nasturtium officinale R. Br. (Suteresi)}

Rizomlu çok yıllık otsu bitkiler. Yapraklar pinnat parçalı; lateral segmentler dikdörtgenimsi eliptik, uç segmenti ise yarı dairesel. Petaller beyaz renkli. Silikuva meyve $11-18 \mathrm{~mm}$ boyunda. Ülkemizde oldukça geniş bir yayılış bu tür, yetişme ortamı olarak ise deniz seviyesinden başlayarak 1650 m’ye kadar olan yüksekliklerdeki dere, gölcük ve kanalları tercih eder. Çiçeklenme zamanı ise Mart-Temmuz aylarıdır. ÇBFCB. 


\section{Ricotia sinuata Boiss. \& Heldr. (Eğri Cavlak) (Türkiye Endemiği)}

Bu tür, Ricotia carnosula türüne çok benzer, ancak petallerin 7-9(-10) mm boyunda olması ve meyve' nin 7-8 tohumlu olması ile ayrılır. Nisan ayında çiçeklenen bu tür, yetişme ortamı olarak deniz seviyesinden başlayarak 1000 m'ye kadar olan yüksekliklerdeki kayalık yamaçları ve uçurumları tercih eder. Akd. El.

\section{Familya: Campanulaceae (Çançiçeğigiller)}

\section{Asyneuma compactum (Boiss. \& Heldr.)} Damboldt var. compactum (Sıkıdeğnek) (Türkiye endemiği) (Fig. 19)

20 cm'ye kadar boylanabilen, kümemsi çok yıllık otsu bitkiler. Taban yaprakları yoğun ve ters mızraksı. Kaliks $4 \mathrm{~mm}$ boyunda. Korolla mavi renkli. Kapsül meyve elipsiod. Ülkemize özgü olan bu varyete, 450-2400 m'ler arasındaki kalkerli kayalık ve taşlık alanlarda yetişmektedir. Çiçeklenme zamanı ise Mayıs-Temmuz aylarıdır. D. Akd. (dağ) El.

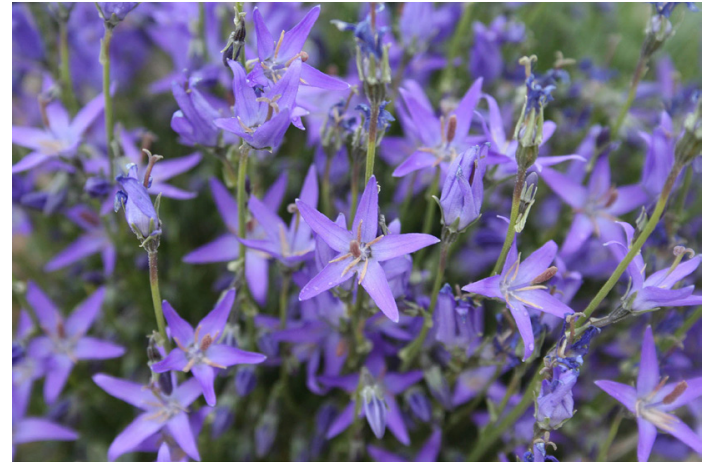

Fig. 19. Asyneuma compactum var. compactum

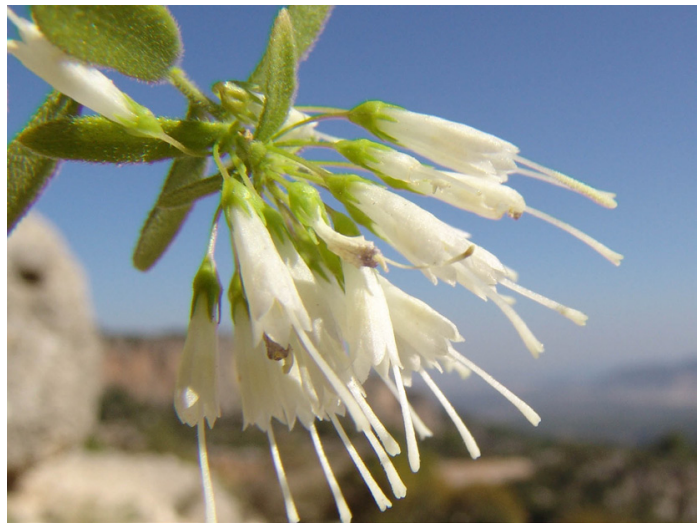

Fig. 20. Campanula buseri
Campanula buseri Damboldt (Gevrek Çan) (Fig. 20)

Narin gövdeli, çok dallı, sert tüylü veya tüysüz çok yıllık bitkiler. Taban ve gövde yaprakları mızraksıdan ters yumurtamsıya kadar değişen şekillerde. Korolla dar silindirik-huni biçimli, beyazdan krem rengine kadar değişen renklerde. Kapsül meyve 3 mm uzunluğunda. Ülkemizde Denizli, Konya, Mersin ve Antalya illerinde, ülkemiz dışında ise Batı Suriye'de yayılış gösterir. Yetişme ortamı olarak 1000-1300 m'ler arasındaki kayalıklarda yetişen bu tür, Temmuz-Ekim aylarında çiçeklenir. ÇBFCB.

\section{Campanula drabifolia Sibth. \& Sm. (Çan Çiçeği)}

Eğik tırmanışlı-dik gövdeli, 25 cm'ye kadar boylanabilen bir yıllık otsu bitkiler. Yapraklar dikdörtgenimsi. Kaliks lopları mızraksı. Korolla çan şeklinde, 10-15 mm boyunda, mavi-menekşe renkli. Meyve kapsül. 10-1000 m'ler arsındaki kayalık tepeliklerinde, kireçtaşlı kaya yarıklarında ve yol kenarlarında yetişen bu tür, Mart-Mayıs aylarında çiçeklenir. ÇBFCB.

\section{Campanula peregrina L. (Cennetçanı) (Fig. 21)}

100 cm'ye kadar boylanabilen, sert dikenli iki yıllık otsu bitkiler. Gövde dik veya eğik yükselişli ve oluklu. Taban ve alt yapraklar yumurtamsı, ters yumurtamsı veya dikdörtgenimsi. Korolla geniş çan şeklinde, açık veya koyu mavi renkli. Kapsül meyve ters konik. Ülkemizde Akdeniz Bölgesi'nde, ülkemiz dışında ise Kıbrıs ve Lübnan'da yayılış gösteren bu tür Haziran-Eylül aylarında çiçeklenir. Yetişme ortamı olarak ise 270-1220 m'ler arasındaki nemli yerleri tercih eder. ÇBFCB. 


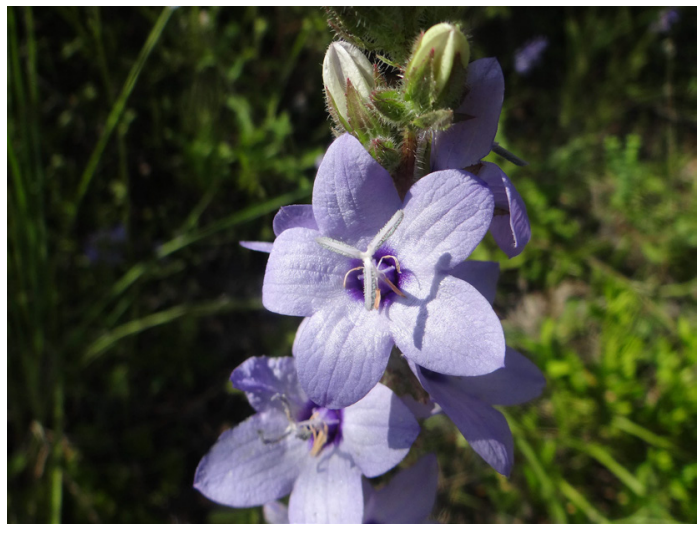

Fig. 21. Campanula peregrina

Familya: Caprifoliaceae (Hanımeligiller)

Centranthus longiflorus Steven subsp. longiflorus (Mahmuzçiçeği) (Fig. 22)

Rizomlu çok yıllık otsu bitkiler. Gövde dik veya yükselici, dallı, 70-200 cm boyunda. Yapraklar şeritsiden mızraksıya kadar değişir. Korolla pembe, nadiren beyaz renkli. Aken meyve sırt kısmından basık. Nisan-Eylül aylarında çiçeklenen bu alt tür, yetişme ortamı olarak deniz seviyesinden 2300 m'ye kadar olan yüksekliklerdeki kayalık yamaçları ve dağ eteklerindeki taş yığınlarını tercih eder. Ir.-Tur. El.

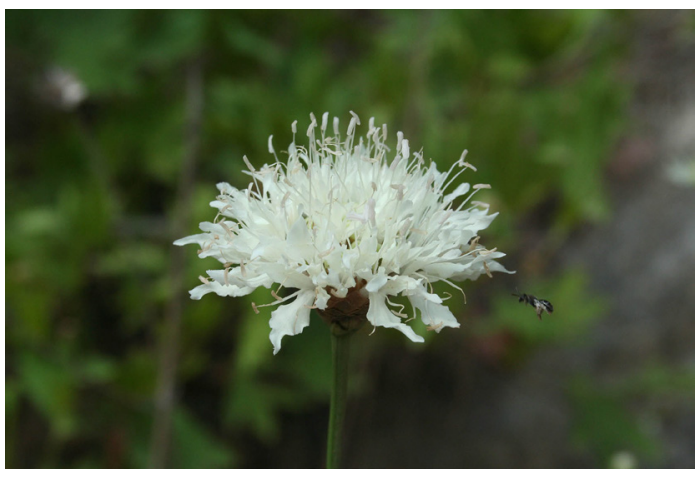

Fig. 23. Cephalaria isaurica
Legousia falcata (Ten.) Fritsch ex Janch (Eğri Kadınaynası)

20-50 cm boyunda, basit gövdeli bir yıllık otsu bitkiler. Yapraklar yumurtamsıdan yumurtamsımızraksıya kadar değişen şekillerde. Kaliks Iopları şeritsi-mızraksı. Korolla menekşe renkli. Meyve kapsül. Nisan-Temmuz aylarında çiçeklenen bu tür, yetişme ortamı olarak deniz seviyesinden başlayarak 1400 m'ye kadar olan yüksekliklerdeki makilikleri, stebi, tarlaları, yol kenarlarını ve kum tepelerini tercih eder. Akd. El.

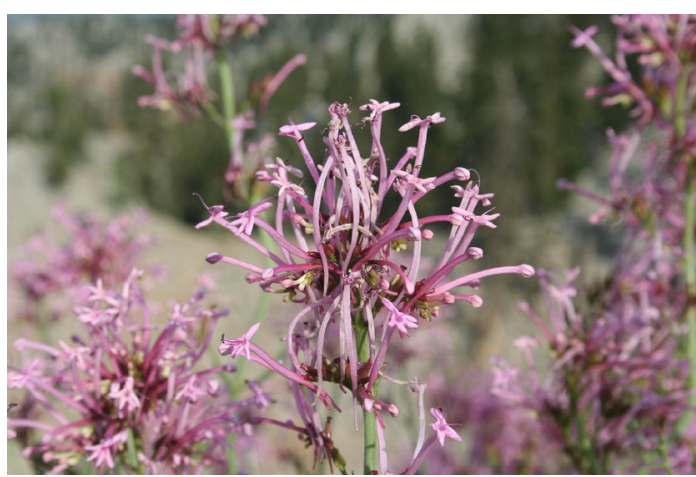

Fig. 22. Centranthus longiflorus subsp. longiflorus Cephalaria isaurica Matthews (Kargı Pelemir) (Türkiye Endemiği) (Fig. 23)

$130 \mathrm{~cm}$ 'ye kadar boylanabilen çok yıllık otsu bitkiler. Yapraklar derimsi, çıplak; alt ve üst yapraklar basit, eliptik. Kapitula 1,5-2 cm çapında. İnvolukral brakteler yumurtamsı. Reseptakular brakteler dikdörtgenimsi-yumurtamsı. Kaliks fincan şeklinde. Korolla sarı renkli. Meyveli involusel 4 eşit dişli. Ülkemize özgü olan bu tür, sadece Antalya ve Karaman illerinde yayılış gösterir ve Ağustos ayında çiçeklenir. Yetişme ortamı olarak ise 30-1100 m’ler arasındaki yamaçları, taşlık alanları, yol kenarlarını, taşlık alanları, karaçam altı ve açıklıklarını tercih eder. Akd. El.

\section{Cephalaria scoparia Contandr. \& Quézel (Süpürge Pelemir) (Antalya Endemiği) (Fig. 24)}

80 cm'ye kadar boylanabilen çok yıllık otsu bitkiler. Gövde dik veya yükselici. Taban yaprakları basit veya lirat paraçall; basit yapraklar şeritsi-dikdörtgenimsi. İnvolukral brakteler dairesel. Reseptakular brakteler mızraksı-kamamsı. Kaliks fincan şeklinde. Korolla açık mavi, pembemsi-mor 
renkli. Meyveli involusel 4 uzun 4 kısa dişli. Ülkemize özgü olan bu tür, sadece Antalya ilinde yayıış göstermektedir. Yetişme ortamı olarak 14002300 m'ler arasındaki kayalık yerleri, karaçam ve sedir açıklıklarını tercih eder. Çiçeklenme zamanı ise Haziran-Ağustos aylarıdır. Akd. El.

\section{Scabiosa atropurpurea L. (Mor Uyuzotu)}

20-60 cm boyunda iki veya çok yıllık otsu bitkiler. Alt yapraklar dikdörtgenimsi veya lirat parçalı. Involukral brakteler mıraksı. Korolla leylak-pembeden mavimsi-leylak renkli. Meyveli involusel

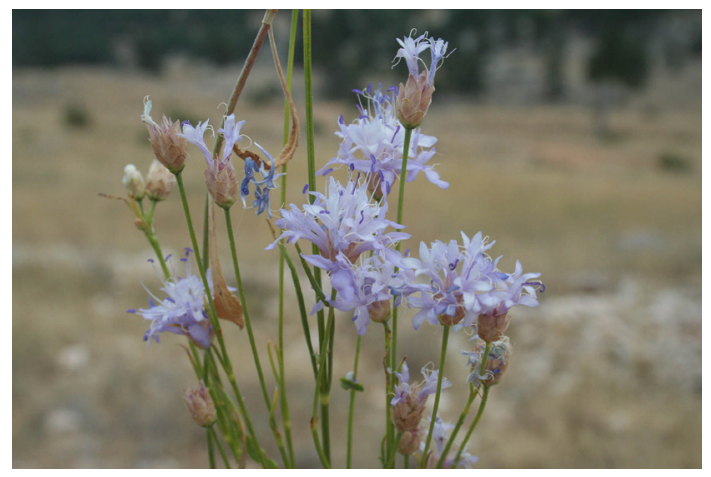

Fig. 24. Cephalaria scoparia 1,5-2 mm boyunda. Kaliks 3-7 setalı. Mayıs-Ağustos (Ekim) aylarında çiçeklenen bu tür, yetişme ortamı olarak deniz seviyesinden başlayarak 1200 m'ye kadar olan yüksekliklerdeki yol kenarlarını, kuru tarlaları ve kumul alanları tercih eder. ÇBFCB.

\section{Valerianella obtusiloba Boiss. (Gül Kuzugevreği)}

$30 \mathrm{~cm}$ 'ye kadar boylanabilen bir yıllık otsu bitkiler. Taban yaprakları kaşıksı veya kamamsı. Çiçek durumu küresel. Çiçekler pembe veya leylak. Meyve $6 \mathrm{~mm}$, kaliks $10 \mathrm{~mm}$, loplar 6 , uçlarda ve kenarlarda çengelli. 1100 m’ye kadar olan yüksekliklerdeki, tarlalarda, yol kenarlarında ve kayalık yamaçlarda yetişir. Çiçeklenme zamanı ise Nisan-Haziran aylarıdır. Akd. El.

\section{Familya: Caryophyllaceae (Karanfilgiller)}

\section{Arenaria deflexa Dec. subsp. microsepala McNeill (Çöp Kumotu) (Türkiye Endemiği)}

Narin yapılı, 5-40 cm boyunda, yoğun salgılı tüylü. Yapraklar ters mızraksı-eliptik, keskin sivri uçlu. Sepaller 2.5-5 mm boyunda. Petaller beyaz renkli. Kapsül meyve dar yumurtamsı. Ülkemize özgü olan bu bitki, Denizli, Muğla ve Antalya illerinde yayılış göstermektedir. Bu alt tür, yetişme ortamı olarak deniz seviyesinden başlayarak 1800 m’ye kadar olan yüksekliklerdeki kayalıkları tercih eder. Akd. El.

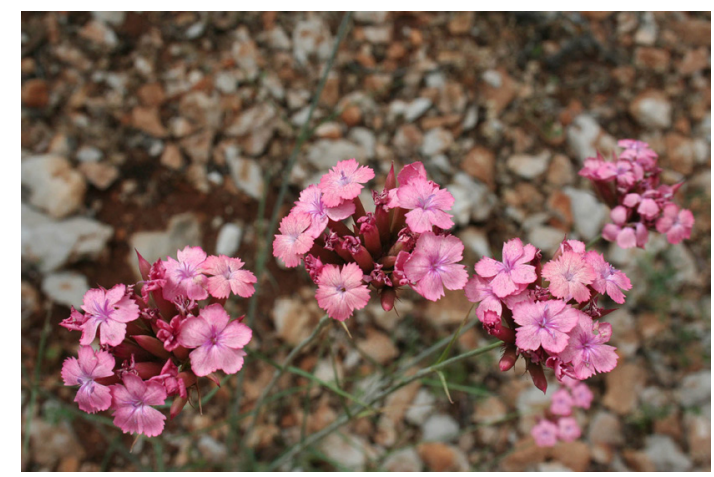

Fig. 25. Dianthus calocephalus
Dianthus calocephalus Boiss. (Güzel Karanfil) (Fig. 25)

30-70 cm boyunda çok yıllık otsu bitkiler. Yapraklar şeritsi, uzun keskin sivri uçlu. Kaliks 16-20 mm boyunda. Petaller pembe-kırmızı renkli, dudakları dişli, ince püsküllü. Meyve kapsül. İlk kez Manisa'dan toplanarak bilim dünyasına tanıtılan bu yabani karanfil türü, 400-2300 m'ler arasındaki kum tepelerini, volkanik ve kireçtaşlı yamaçları, stebi, tarlaları, açık alanları ve kayalıkları tercih eder. ÇBFCB.

Dianthus crinitus Sm. var. crinitus (Uzun Çanak) (Fig. 26)

Sağlam yapılı, dik, 19-32 cm boyunda çok yıllık otsu bitkiler. Yapraklar düz, şeritsi. Kaliks 25-35 $\mathrm{cm}$ boyunda. Brakteoller yumurtamsı. Petal dudakları beyazdan pembeye kadar değişen renklerde, saçaklı. Meyve kapsül. Mayıs-Ağustos aylarında çiçeklenen bu varyete yetişme ortamı olarak 800-2600 m'ler arasındaki kayalık yamaçları ve dağlık yamaçları tercih eder. ÇBFCB. 


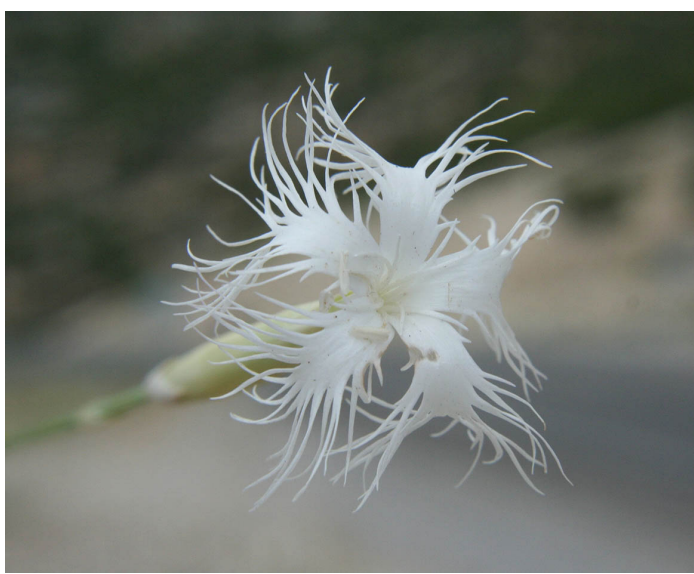

Fig. 26. Dianthus crinitus var. crinitus

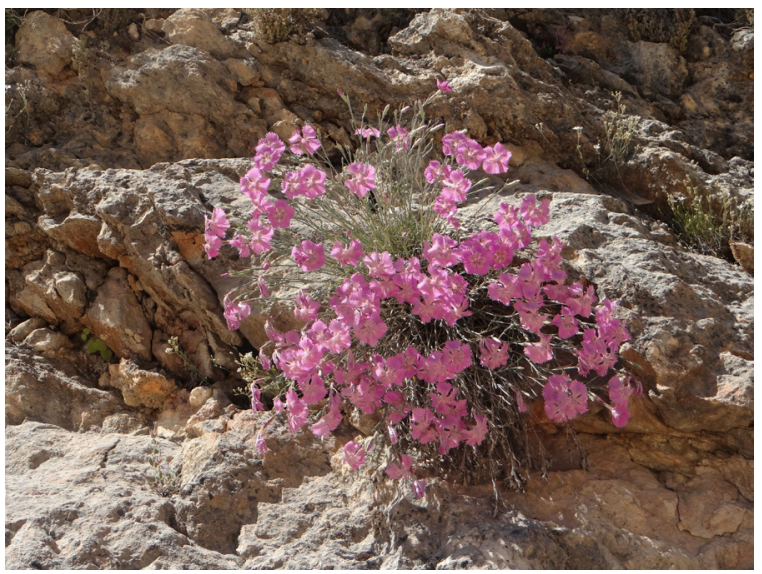

Fig. 27. Dianthus zonatus var. zonatus

Dianthus zonatus Fenzl var. zonatus (Kaya Karanfili) (Fig. 27)

7-30 cm boyunda, çok yıllık bitkiler. Yapraklar, şeritsi. Kaliks $15 \mathrm{~mm}$ 'den uzun, yarı silindirik. Petal dudakları 8-11 mm boyunda, dişli, pembe renkli, boğazı koyu halkalı, aşağıda sarı renkli. Meyve kapsül. Ülkemiz dışında Batı Suriye'de de yetişen bu bitki, Mayıs-Ağustos aylarında çiçeklenir. Yetişme ortamı olarak ise 700-2600 m’ler arasındaki kayalık yerleri ve tarlaları tercih eder. ÇBFCB.

\section{Minuartia mesogitana (Boiss.) Hand.-Mazz. subsp. kotschyana (Boiss.) McNeill (Uysal Tıstıs)}

Gövde kalkık uçlu, eğik tırmanışlı veya hemen hemen dik, 20 cm'ye kadar boylanabilen bir yıllık otsu bitkiler. Yapraklar şeritsi-biz biçimliden bizbiçimli-kılsıya kadar değişen şekillerde. Petaller beyaz renkli. Meyve kapsül. Nisan-Temmuz aylarında çiçeklenen bu alt tür, 200-1800 m’ler arasında yetişir. ÇBFCB.

\section{Paronychia chionaea Boiss. subsp. chionaea var. chionaea (Deli Kepekotu)}

Çoğunlukla tabanda odunsu, yatık gövdeli, kümeli, çok yıllık otsu bitkiler. Yapraklar ters yumurtamsı-kaşıksı. Brakteler geniş yumurtamsıdan dikdörtgenimsiye kadar değişen şekillerde. Çiçekler 2,5-3,25 mm boyunda. Sepaller dar dikdörtgenimsi. Meyve sepallere eşit. Çiçeklenme zamanı ise Haziran-Ağustos ayları olan bu varyete, 2800 m’ye kadar olan yüksekliklerdeki kayalık yerler tercih eder. ÇBFCB.

\section{Petrorhagia dubia (Raf.) G.Lopez \& Romo (Zarkaranfil)}

Hemen hemen dik gövdeli, 6-40 cm boyunda, bir yıllık otsu bitkiler. Yapraklar şeritsiden şeritsidikdörtgenimsiye kadar değişen şekillerde. Brakteler zarımsı, kaliksi sarar. Kaliks 10-13 mm boyunda. Petaller pembe veya mor renkli. Bu tür ülkemiz dışında, Akdeniz havzasında, Azerbaycan'da, Güney Afrika'da, Avustralya'da ve Hawaii'de de yayılış göstermektedir. NisanHaziran aylarında çiçeklenen bu tür, yetişme ortamı olarak deniz seviyesinden başlayarak 400 m’ye kadar olan yüksekliklerdeki tarlaları, yol kenarlarını ve tepelik alanları tercih eder. ÇBFCB.

\section{Silene colorata Poir. subsp. colorata (Kum Nakılı)}

Dallı bir yıllık otsu bitkiler. Alt yapraklar yumurtamsı-kaşıksı. Kaliks 10-18 mm boyunda tüylü. Petaller pembe veya beyazımsı, dudaklar ise derin iki parçalı. Antofor 5-8 $\mathrm{mm}$ boyunda ve tüylü. Meyve kapsül. Ülkemizde Ege ve Akdeniz bölgelerinde yayılış gösteren bu alt tür, Mart-Haziran aylarında çiçeklenir. Yetişme ortamı olarak deniz seviyesinden başlayarak 800 m'ye kadar olan yüksekliklerdeki kumulları, kayalık yamaçları ve tarlaları tercih eder. Akd. El. 
Silene compacta Fisch. ex Hornem.

(Kanlıbasıra Otu) (Fig. 28)

İki veya kısa ömürlü çok yıllık otsu bitkiler. Gövde tamamen çıplak, dik ve 120 cm'ye kadar boylanır. Alt yapraklar rozet formunda, mıraksı-kaşıksı. Gövde yaprakları genellikle yumurtamsı. Kaliks 16$20 \mathrm{~mm}$ boyunda, çıplak. Petaller parlak pembe renkli. Antofor 8-12 mm boyunda ve çıplak. Kapsül meyve dikdörtgenimsi. Ülkemizde oldukça geniş bir yayılış alanına sahip olan bu tür, Mayıs-Ağustos aylarında çiçeklenir. Yetişme ortamı olarak ise deniz seviyesinden başlayarak 2100 m'ye kadar olan

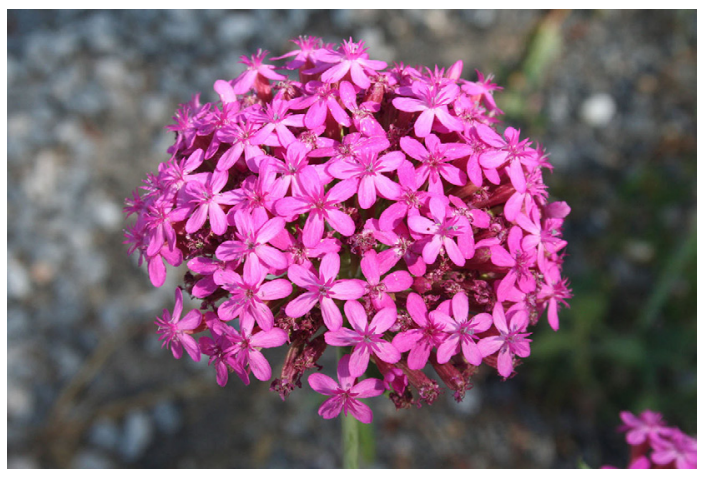

Fig. 28. Silene compacta yüksekliklerdeki yamaçları ve orman açıkıklarını tercih eder. ÇBFCB.

\section{Silene italica (L.) Pers. subsp. italica (Yuğuşyüreği)}

Dik gövdeli, çok yıllık, tüylü ve 80 cm'ye kadar boylanabilen bitkiler. Taban yaprakları ters yumurtamsıdan mızraksıya kadar değişen şekillerde. Kaliks tüpsü, seyrek tüylü. Petaller krem veya beyazımsı renkli, derin iki parçalı. Antofor 7-11 mm boyunda. Meyve kapsül. illk kez İtalya'dan toplanarak bilim dünyasına tanıtılan bu alt tür, yetişme ortamı olarak (50-)650-2400 m'ye kadar olan karaçam açıkıklarını ve kayalık yerleri tercih eder. ÇBFCB.

\section{Velezia pseudorigida Hub.-Mor. (Has Tığotu) (Türkiye Endemiği)}

Üst kısımda dallanmış, dik veya eğik tırmanışlı, 10-30 cm boyunda bir yıllık otsu bitkiler. Kaliks 12-13 mm boyumda ve salgılı tüylü. Petaller iki parçalı veya küçük dişli. Kapsül meyve $10 \mathrm{~mm}$ boyunda. Ülkemize özgü olan bu tür, Antalya, Muğla ve İzmir illerinde yayılış göstermektedir. Mayıs ayında çiçeklenen bu bitki makilikleri ve kayalık yerleri tercih eder. Akd. El.

Familya: Cistaceae (Ladengiller)

\section{Helianthemum nummularium (L.) Miller subsp. nummularium (Güngülü)}

Yarı çalımsı çok yıllık bitkiler. Yapraklar çor dar eliptikten dikdörtgenimsiye kadar değişen şekillerde. Korolla sarı renkli. Bu türün ülkemizde yetişen 4 alt türünden birisi olan bu bitki NisanAğustos aylarında çiçeklenir. Yetişme ortamı olarak ise 1000-2100 m’ler arasındaki kayalık yamaçları tercih eder. ÇBFCB.

\section{Familya: Cleomaceae (Saçakgülügiller)}

\section{Cleome ornithopodioides L. (Taş Saçakgülü)}

Narin yapılı 50 cm'ye kadar boylanabilen dik gövdeli bir yıllık otsu bitkiler. Yapraklar 3 yaprakçıkı; yaprakçıklar dar eliptik veya eliptik. Çiçek durumu salkım, 7-30 çiçekli. Petaller beyaz, krem ve pembemsi renkli. Kapsül meyve şeritsi. 20-1750 m'ler arasındaki kayalık yerlerde, açık alanlarda, ormanlık alanlarda ve nemli yerlerde yetişen bu tür, Nisan-Ağustos aylarında çiçeklenir. Akd. El.

\section{Familya: Crassulaceae (Damkoruğugiller)}

\section{Prometheum sempervivoides (Fischer ex M. Bieb.) H.Ohba (Horozlelesi)}

Dik gövdeli, 7-20 cm boyunda iki yıllık otsu bitkiler. Taban yaprakları rozet formunda. Yapraklar yumurtamsı. Gövde yaprakları küçük. Çiçek durumu 30-150 çiçekli. Sepaller 2-4 mm boyunda. 
Petaller koyu kırmızı renkli, 6-8 mm boyunda. Ülkemizde geniş bir yayılış alanına sahip olan bu tür, 1200-2900 m'ler arasındaki kayalık yamaçları ve kaya yarıklarını tercih eder. Çiçeklenme zamanı ise Haziran-Ağustos (Eylül) aylarıdır. ÇBFCB.

\section{Sedum pallidum M.Bieb. (Koyunörmece)}

Hemen hemen dik gövdeli bir yıllık otsu bitkiler. Yapraklar şeritsi-yarı sivrilen silindirsi, Sepaller 1-2 mm boyunda. Petaller beyaz veya soluk pembe, pembe orta damarlı. Haziran-Ağustos aylarında çiçeklenen bu bitki, yetişme ortamı olarak deniz seviyesinden başlayarak 1900 m’ye kadar olan yüksekliklerdeki yaprak döken ormanları ve kayalıkları tercih eder. ÇBFCB.

\section{Umbilicus luteus (Huds.) Webb \& Berthel (Sarı Göbekotu)}

Sağlam yapılı, yumrulu, çok yıllık otsu bitkiler. Gövde dik, basit ve $30-80 \mathrm{~cm}$ boyunda. Alt yapraklar dairesel-kalkansı. Gövde yaprakları yumurtamsı-üçgensi. Çiçek durumu salkım. Korolla tüpsü, yeşilimsi sarı renkli. Folikül meyve çok tohumlu. Bu tür 900-2300 m’ler arasındaki kayalık yerleri ve vadi yamaçlarını yetişme ortamı olarak tercih eder ve (Mayıs) Haziran-Ağustos ayında çiçeklenir. ÇBFCB.

\section{Familya: Cucurbitaceae}

\section{Bryonia cretica L. (Karahaylin)}

Çok yıllık tırmanıc bitkiler. Yapraklar yumurtamsı-kalpsi, derin 5-7 loplu; loplar mızraksı veya yumurtamsı. Sülükler dallanmamış. Çiçekler yeşilimsi-sarı veya yeşilimsi-beyaz renkli. Meyve küçük, üzümsü, küresel, kırmızı renkli. Mayıs ayında çiçeklenen bu tür değişik çalıların üzerinde yaşar. Akd. El.

\section{Familya: Euphorbiaceae (Sütleğengiller)}

Chrozophora tinctoria (L.) A. Juss. (Siğilotu)

Eğik tırmanışlı, çoğunlukla tabanda odunlu, 30-100 cm boyunda bir yıllık otsu bitkiler. Yapraklar açılı-yumurtamsıdan yumurtamsı-mızraksıya kadar değişen şekillerde. Petaller sarı renkli. Şizokarp meyve 3 loplu. Ülkemizde oldukça geniş bir yayılış alanına sahip olan bu tür, Mart-Eylül aylarında çiçeklenir. Yetişme ortamı olarak ise deniz seviyesinden başlayarak 1530 m'ye kadar olan yüksekliklerdeki makilikleri, friganayı, kızılçam açıklıklarını, taşlı yerleri, tuzlu stebi ve tarlaları tercih eder. ÇBFCB.

\section{Euphorbia chamaesyce L. (Şebrem)}

Yatık gövdeli, çoğunlukla yabanda çok dallı bir yıllık otsu bitkiler. Yapraklar asimeterik, yarıdairesel-yumurtamsıdan yumurtaması-dikdörtgenimsiye kadar değişen şekillerde. Meyve $2 \mathrm{~mm}$ çapında. Mayıs-Ekim aylarında çiçeklenen bu tür, yetişme ortamı olarak deniz seviyesinden başlayarak 1600 m’ye kadar olan yüksekliklerdeki kayalık tepelikleri, tuzlu ve kumlu toprakları göl kenarlarını ve tahrip edilmiş alanları tercih eder. ÇBFCB.

\section{Euphorbia hierosolymitana Boiss. var. hierosolymitana (Çalı Sütleğeni) (Fig. 29)}

3 m'ye kadar boylanabilen dikensiz çalılar. Gövde ve ışın yaprakları eliptikten eliptik-ters yumurtamsıya kadar değişen şekillerde veya şeritsi-mızraksı. Çiçek durumu siyatyum. Meyve kapsül ve $5 \mathrm{~mm}$ çapında. Ülkemizde İzmir, Muğla ve Antalya illerinde, ülkemiz dışında ise Kıbrıs ve Batı Suriye'de yayılış gösterir. Ocak-Haziran aylarında çiçeklenen bu varyete, 5-300 m’ler arasındaki kireçtaşlı kayalıkları ve orman açıklıklarını tercih eder. Akd. El. 


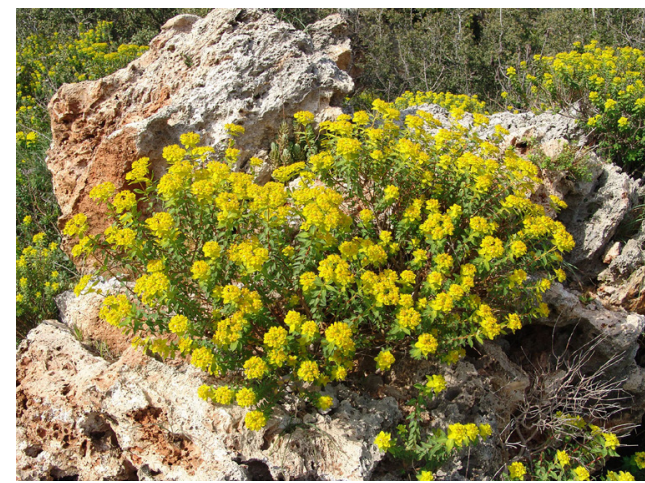

Fig. 29. Euphorbia hierosolymitana var. hierosolymitana

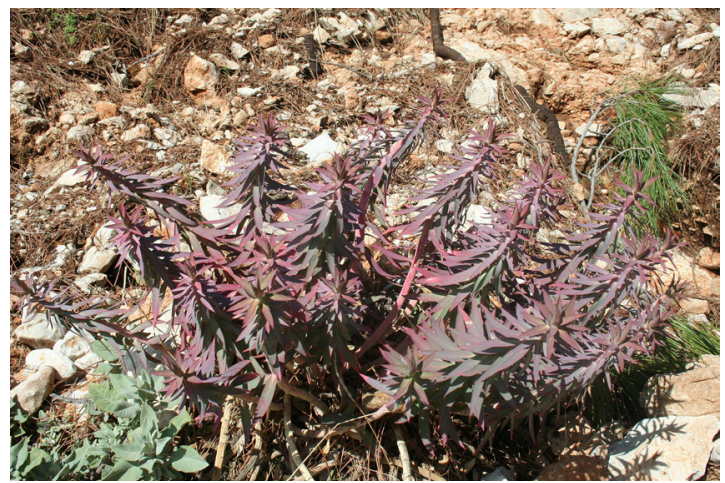

Fig. 30. Euphorbia rigida

Euphorbia rigida Bieb. (sütleğen) (Fig. 30)

Sağlam yapılı çok yıllık otlar. Gövde yoğun yapraklı ve 60 cm'ye kadar boylanır. Gövde yaprakları mızraksı, kalın ve etli. Işın yaprakları yumurtamsı-mızraksı veya yumurtamsı. Çiçek durumu siyatyum. Meyve kapsül ve yumurtamsı-konik. Mart-Ağustos aylarında çiçeklenen bu tür, ülkemizde Marmara, Ege ve Akdeniz bölgelerinde, ülkemiz dışında ise Fas ve Portekiz'den ve Kırım'a kadar geniş bir yayılış gösterir. Yetişme ortamı olarak ise deniz seviyesinden başlayarak 2000 m’ye kadar olan yüksekliklerdeki kızılçam orman açıklıklarını, kermes meşesi meşeliklerini, friganayı ve kireçtaşlı kayalıkları tercih eder. Akd. El.

Familya: Fabaceae (Baklagiller)

\section{Astragalus angustifolius Lam. subsp. angustifolius (Keçi Geveni)}

Yastık formunda olan dikenli çalılar. Yapraklar paripinnat; yaprakçıklar eliptikten ters yumurtamsıya kadar değişen şekillerde. Kaliks tüpsü. Korolla beyaz renkli. Baklamsı meyve dikdörtgenimsi, yoğun basık beyaz tüylü. Nisan-Ağustos aylarında çiçeklenen bu dikenli geven, yetişme ortamı olarak 800-2900 m'ler arasındaki taşlık alanları ve stebi tercih eder. ÇBFCB.

\section{Coronilla scorpioides (L.) W. D. J. Koch (Akrep Burçağı)}

10-50 cm boyunda bir yıllık otsu bitkiler. Yapraklar yeşilimsi-pulsu, alttakiler basit üstteki yapraklar ise 3 yaprakçıkı. Şemsiye çiçek durumu 2-5 çiçekli. Çiçekler 4-8 mm boyunda ve sarı renkli. Boğumlu meyve 2-6 cm boyunda, yaysı. Mart-Temmuz aylarında çiçeklenen bu tür, 1000 m'ye kadar olan yüksekliklerdeki kültür alanlarında, tahrip edilmiş alanlarda, taşlık alanlarda ve yol kenarlarında yetişir. ÇBFCB.

Dorycnium pentaphyllum Scop. subsp. haussknechtii (Boiss.) Gams. (Gervenük) (Türkiye Endemiği)

15-60 cm boyunda, yoğun ipeksi tüylü, çok yıllık otlar veya küçük yarı çalılar. Yapraklarçıklar şeritsi-ters mızraksı, 8-20 mm boyunda. Çiçek durumu 4-30 çiçekli. Çiçekler 4-6 mm boyunda, beyaz pembe veya mor mahmuzlu. Kaliks zayıfça iki dudaklı, 2-5 mm boyunda. Baklamsı meyve yumurtamsı-küresel. Ülkemize özgü olan bu bitki, Mayıs-Ağustos aylarında çiçeklenir. 200-1650 m’ler arasındaki yüksekliklerdeki kuru kireçtaşlı yamaçlarda, kermes meşesi makiliklerinde, konifer ormanlarında ve kızılçam altlarında yetişir. ÇBFCB. 


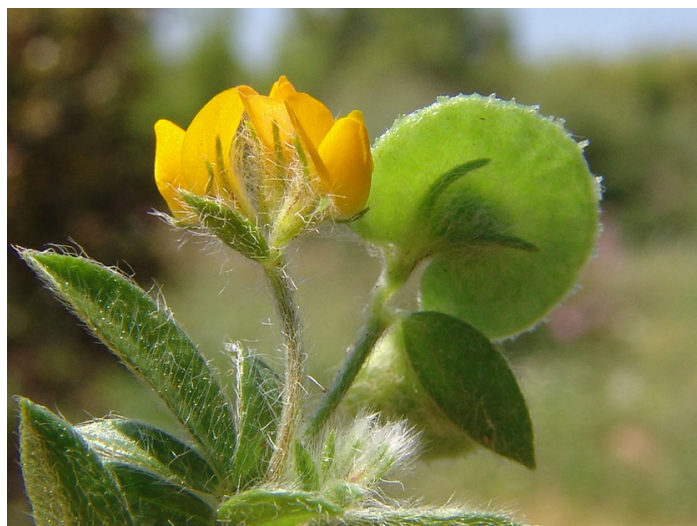

Fig. 31. Hymenocarpos circinnatus

Hymenocarpos circinnatus (L.) Savi (Pullu Ot) (Fig. 31)

Seyrek tüylü, 35 cm'ye kadar boylanabilen bir yıllık otsu bitkiler. Yapraklar basit veya imparipinnat. Korolla sarı renkli. Meyve böbreksi, düz veya dişli kenarlı. Ülkemizin büyük bir kesiminde yayılış gösteren bu tür, yetişme ortamı olarak deniz seviyesinden başlayarak 1500 m'ye kadar olan yüksekliklerdeki tahrip edilmiş alanları, makilikleri ve çam ormanlarını tercih eder. ÇBFCB.

Lathyrus stenophyllus Boiss. \& Heldr. (Alanya Burçağı)

Serilici gövdeli veya yükselici, çıplak bir yıllık otsu bitkiler. Gövde darca kanatlı ve $40-70 \mathrm{~cm}$ boyunda. Yaprakçıklar şeritsi. Korolla gül kırmızısı veya açık pembe renkli. Legümen meyve darca oblong. Bu tür ülkemizde sadece Antalya ve Mersin illerinde ülkemiz dışında ise Girit ve Batı Suriye'de yayılış göstermektedir. Akd. El.

\section{Lupinus pilosus L. (Gavur Baklası) (Fig. 32)}

50 cm'ye kadar boylanabilen, yumuşak sık tüylü, bir yıllık otsu bitkiler. Yapraklar parmaksı; yaprakçıklar, dikdörtgenimsi-ters yumurtamsı. Korolla mavi renkli, standart beyaz lekeli. Baklamsı meyve kaba tüylü, 35-60 mm boyunda. Bu tür yetişme ortamı olarak deniz seviyesinden 500 m’ye kadar olan yüksekliklerdeki makilikleri, kumul alanları ve tarlaları tercih eder. Türün çiçeklenme zamanı Mart-Mayıs aylarıdır. Akd. El.

\section{Melilotus indicus (L.) All. (Otuzlu Yonca)}

$50 \mathrm{~cm}$ 'ye kadar boylanabilen bir yıllık otsu bitki-

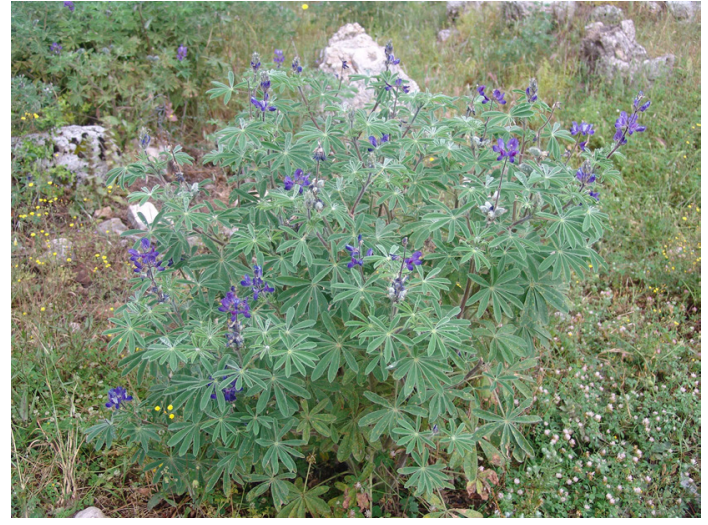

Fig. 32. Lupinus pilosus ler. Yapraklar 3 yaprakçıkı. Çiçek durumu uzamış salkım. Korolla sarı renkli. Meyve kısa, açılmayan tipte. Şubat-Mayıs aylarında çiçeklenen bu bitki, yetişme ortamı olarak deniz seviyesinden 1750 m’ye kadar olan yüksekliklerdeki nemli yerleri tercih eder. ÇBFCB.

\section{Onobrychis caput-galli (L.) Lam. (PItrak Korunga)}

45 cm'ye kadar boylanabilen yatık gövdeli, dallı bir yıllık bitkiler. Yaprak parçalı; yaprakçıklar şeritsi-dikdörtgenimsi. Korolla pembe veya pembemsi-mor. Meyve yarı-dairesel, çok sayıda dikenli. Yetişme ortamı olarak deniz seviyesinden 800 m'ye kadar olan yüksekliklerdeki kayalık yamaçları, tahrip edilmiş stebi, yol kenarlarını ve deniz kıyılarını tercih eden bu tür, Nisan-Mayıs aylarında çiçeklenir. Akd. El.

\section{Ononis pubescens L. (Havlı Örsele) (Fig. 33)}

Tabanda dallı, bir yıllık otlar. Gövde yapışkan tüylü ve uzun salgısız tüylü, 10-40 cm boyunda. Alt ve en üst yapraklar tek yaprakçıkı, diğerleri 3 yaprakçıklı; yaprakçıklar dikdörtgenimsi veya ters yumurtamsı. Kaliks çan şeklinde. Korolla soluk sarı renkli; standart kırmızı çizgili. Ülkemizin batı, güney ve güney doğu kesimlerinde yetişen bu tür yetişme ortamı olarak deniz seviyesinden 700 
m’ye kadar olan yüksekliklerdeki makilikleri, çam ormanlarını ve tarlaları tercih eder. Akd. El.

Ononis spinosa L. subsp. leiosperma (Boiss) Sirj. (Demir Delen)

Dik veya yükselici, çok yıllık bitkiler. Gövde dikenli, 30-60 cm boyunda. Üst yapraklar tek yaprakçıklı, diğerleri 3 yaprakçıkı; yaprakçıklar yumurtamsıdan dikdörtgenimsiye kadar değişen şekillerde. Korolla pembe, nadiren beyaz renkli, standart mor çizgili. Legümen meyve yumurtamsı. Ülkemizin hemen hemen tüm bölgelerinde yayı-

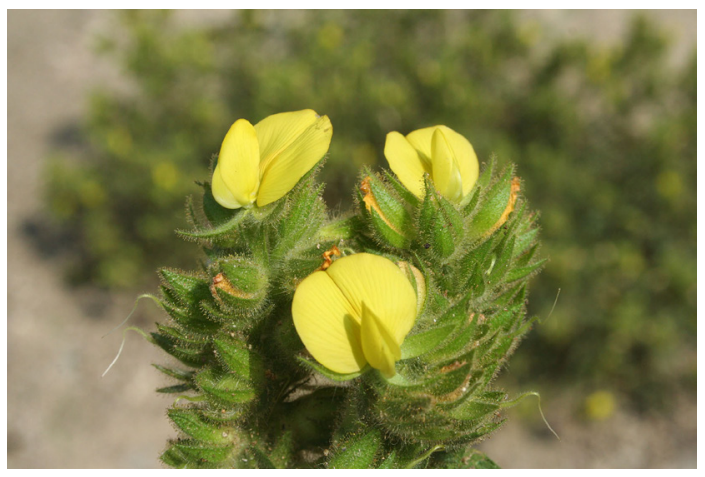

Fig. 33. Ononis pubescens lış gösteren bu tür Mayıs-Ağustos aylarında çiçeklenir. Yetişme ortamı olarak ise deniz seviyesinden 2250 m’ye kadar olan yüksekliklerdeki taşlı yamaçları, üzüm bağlarını ve kültür alanlarını tercih eder. ÇBFCB.

\section{Trifolium globosum L. (Yumak Yonca)}

Yatık gövdeli veya eğik tırmanışlı, 10-40 cm boyunda, bir yıllık otsu bitkiler. Yaprakçıklar ters yumurtamsı, kamamsı. Çiçek durumu çok-çiçekli. Korolla beyaz veya pembe renkli. Meyveli kafa 15-75 mm çapında, küresel. Şubat-Haziran ayında çiçeklenen bu tür, 900 m'ye kadar olan açık tepeliklerde, çalı aralarında ve yol kenarlarında yetişir. ÇBFCB.

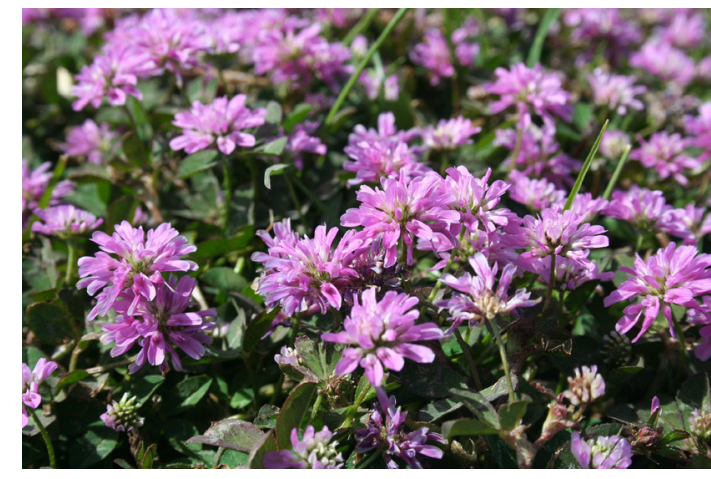

Fig. 34. Trifolium tomentosum var. tomentosum
Trifolium tomentosum L. var. tomentosum (Yünlü Yonca) (Fig. 34)

20 cm'ye kadar boylanabilen, dik veya kalkık uçlu, bir yıllık otsu bitkiler. Yaprakçıklar ters yumurtamsı. Kaliks meyvede şişkin ve tüylü. Korolla pembe renkli. Bu varyete yetişme ortamı olarak deniz seviyesinden 2200 m'ye kadar olan yüksekliklerdeki makilik ve açık alanları tercih eder. Çiçeklenme zamanı ise Şubat-Nisan aylarıdır. ÇBFCB.

\section{Vicia galilaea Plitmann \& Zohary (Deliculban)}

Sağlam yapılı, tüylü, 15-170 cm boyunda bir yıllık otsu bitkiler. Yaprakçıklar yumurtamsıdan dairesel kadar değişen şekillerde. Çiçekler leylak ve beyaz olmak üzere iki renkli. Baklamsı meyve yoğun tüylü. Ülkemizde Antalya, Muğla ve Mersin illerinde, ülkemiz dışında ise Filistin'de yetişen bu tür, yetişme ortamı olarak deniz seviyesinden 1300 m'ye kadar olan yüksekliklerdeki kireçtaşı kayalık yamaçları, tarlaları ve nemli toprakları tercih eder. Çiçeklenme zamanı ise Mart-Mayıs aylarıdır. ÇBFCB.

\section{Vicia villosa Roth subsp. eriocarpa (Hauskkn.) P. W. Ball (Boğala)}

Bir veya iki yıllık tüylü veya çıplak bitkiler. Gövde yükselici veya tırmanıcı. Yaprakçıklar 4-10 parçalı, şeritsi-dikdörtgenimsi. Korolla menekşe renkli. Baklamsı meyve tüylü dikdörtgenimsi. Bu alt tür, yetişme ortamı olarak deniz seviyesinden 1700 m'ye kadar olan yüksekliklerdeki makilikleri çam ormanlarını, su kenarlarını ve tarlaları tercih eder. ÇBFCB. 


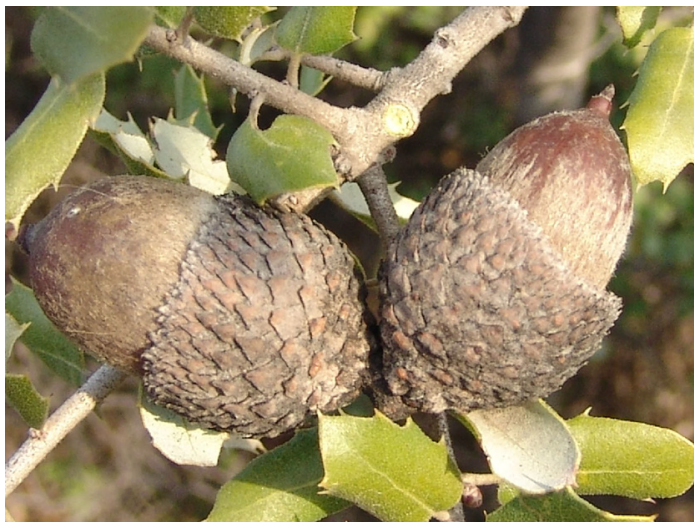

Fig. 35. Quercus aucheri
Familya: Fagaceae (Kayıngiller)

Quercus aucheri Jaub. \& Spach (Boz Pırnal) (Türkiye Endemiği) (Fig. 35)

Herdem yeşil çalılar veya 10 m'ye kadar boylanabilen ağaçlar. Yapraklar genişçe dikdörtgenimsiden yumurtamsıya kadar değişen şekillerde, alt yapraklar tam kenarlı, üst yapraklar testere dişli kenarlı. Pistillat çiçekler tek veya 2'den çok sayıya kadar olan çok kısa çiçek kümesi sapları üzerinde yer alır. Meyve fincan şeklinde kupula tarafından sarılmış fındık. Ülkemize özgü olan bu meşe türü, Aydın, Muğla ve Antalya illerinde yayılış gösterir. Eylül ve

Ekim aylarında meyve veren tür, yetişme ortamı olarak deniz seviyesinden 1700 m'ye kadar olan yüksekliklerdeki makilik alanlardaki kireç taşlı kayalıkları tercih eder. Akd. El.

\section{Familya: Gentianaceae (Gentiyangiller)}

\section{Centaurium pulchellum (Sw.) Druce (Pembe Tukul)}

2-20 cm boyunda, çıplak, bir yıllık otsu bitkiler. Yapraklar yumurtamsı, dikdörtgenimsiden mızraksıya kadar değişen şekillerde. Korolla pembe'den mor'a kadar değiş̧en renklerde, nadiren beyaz renkli. Ülkemizde geniş bir yayılış alanına sahip olan bu tür, Nisan-Temmuz aylarında çiçeklenir. Yetişme ortamı olarak ise deniz seviyesinden 2600 m’ye kadar olan yüksekliklerdeki bataklık alanları, kuru kayalık tepelikleri, açıkıkları tercih eder. ÇBFCB.

\section{Familya: Geraniaceae (Turnagagasıgiller)}

\section{Erodium gruinum (L.) L'Hérit (Kargadıdağı) (Fig. 36)}

Hemen hemen sert kıllı tüylü, 7-15 cm boyunda, bir yıllık otsu bitkiler. Taban yaprakları çoğunlukla üç parçalı, uç segmentleri geniş, 3-5-loplu. Gövde yaprakları derin parçalı. Sepaller 8-10 $\mathrm{mm}$ boyunda. Petaller lavanta-mavi renkli. Meyve uzun gagalı, 6-9 cm boyunda. Yetişme ortamı olarak deniz seviyesinden 1000 m'ye kadar olan yüksekliklerdeki kayalık yamaçları ve nemli yerleri tercih eder. Çiçeklenme zamanı ise Şubat-Mayıs aylarıdır. Akd. El.

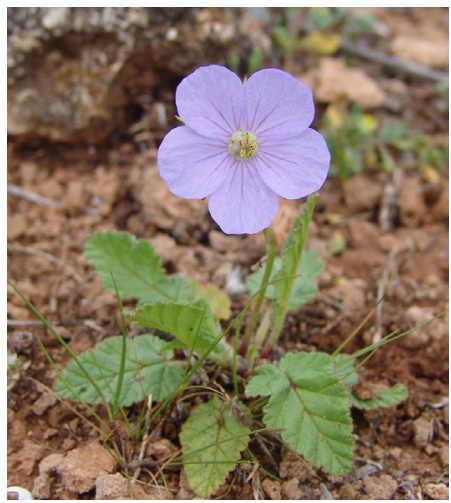

Fig. 36. Erodium gruinum

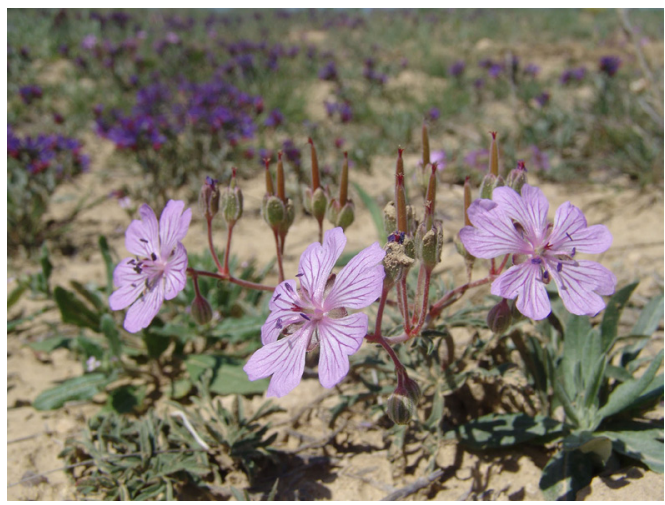

Fig. 37. Geranium tuberosum

Geranium tuberosum L. (Çakmuz) (Fig. 37)

12-30 cm boyunda, dik gövdeli, rizomlu, çok yıllık otsu bitkiler. Taban yaprakları palmatisekt 
parçalı; segmentler eşkenar dörtgenimsiden dikdörtgenimsi-şeritsiye kadar değişen şekillerde. Sepaller 6-7 mm boyunda. Petaller leylak renkli. Kapsül meyve tüylü. Nisan-Haziran aylarında çiçeklenen bu tür, deniz seviyesinden 2500 m’ye kadar olan yüksekliklerdeki taşlı yamaçları ve tahrip edilmiş alanları yetişme ortamları tercih eder. Ir.-Tur. El.

\section{Familya: Hypericaceae (Kantarongiller)}

\section{Hypericum perfoliatum L. (Binbirdelik Otu)}

$80 \mathrm{~cm}$ 'ye kadar boylanabilen, dik veya eğik tırmanışlı, çok yıllık otsu bitkiler. Yapraklar yumurtamsıdan üçgenimsi mızraksıya kadar değişen şekillerde. Sepal dikdörtgenimsi. Petaller 9-14 mm boyunda, sarı renkli, siyah benekli veya değil. Kapsül meyve genişçe yumurtamsı. Ülkemizde Ege ve Batı Akdeniz bölgelerinde yetişen bu tür, Nisan ve Mayıs aylarında çiçeklenir. Yetişme ortamı olarak ise 20-880 m’ler arasındaki gölgeli kayalık yerleri ve nemli yerleri tercih eder. Akd. El.

\section{Hypericum triquetrifolium Turra (Pırpır Otu)}

Dik veya kalkık uçu çok yıllık otsu bitkiler. Gövde 15-55 cm boyunda, dalcıklar genişçe yayılmış formda. Yapraklar üçgenimsi-mızraksı, darca yumurtamsı, şeritsi-dikdörtgenimsi. Petaller 5-7 mm boyunda, sarı renkli, siyah beneksi veya nadiren siyah benekli. Kapsül meyve yumurtamsı. MayısEylül aylarında çiçeklenen bu tür, yetişme ortamı olarak deniz seviyesinden 1250 m'ye kadar olan yüksekliklerdeki kuru taşı veya kumlu açıkıkları veya kültür alanlarını tercih eder. ÇBFCB.

Familya: Lamiaceae (Ballıbabagiller)

Ajuga bombycina Boiss. (Geyik Mayasılı)

(Türkiye Endemiği) (Fig. 38)

Uzun yünsü tüylerle kaplı çok yıllık otlar. Tüm gövde gümüşi-keçemsi tüylerle kaplı ve yatık. Yapraklar ters yumurtamsıdan-ters yumurtamsıdan dikdörtgenimsiye kadar değişen şekillerde. Çiçek durumları 2 çiçekli. Korolla sarı renkli ve kırmızı benekli. Fındıksı meyve buruşuk. Ülkemize özgü olan bu tür, yetişme ortamı olarak 50-1350 m’ler arasındaki kireçtaşı kayalıklarını ve kayalık yamaç-

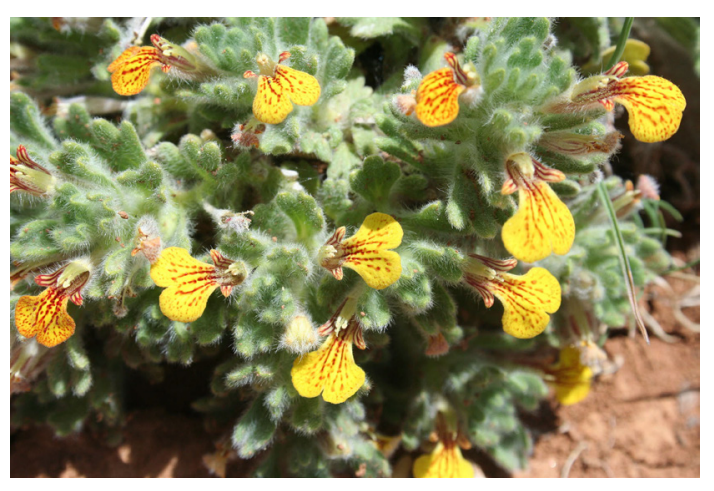

Fig. 38. Ajuga bombycina ları tercih eder. Nisan-Haziran aylarında çiçeklenir. Akd. El.

\section{Ballota cristata P. H. Davis (Tahtalı Nemnem) (Antalya Endemiği)}

Sürünücü ve odunlu toprak altı gövdesine sahip bitkiler. Bitkinin tüm parçaları yoğun yıldızsı tüylü. Gövde dik, 15-28 cm boyunda. Gövde yaprakları yumurtamsı. Çiçek durumları 7-20 çiçekli. Korolla beyaz ve mor lekeli. Meyve fındıksı. Antalya iline özgü olan bu tür, Haziran ve Temmuz aylarında çiçek açmaktadır. Yetişme ortamı olarak ise 1100-1700 m’ler arasındaki kireçtaşlı kayalıkları tercih eder. Akd. El.

\section{Clinopodium nepeta (L.) Kuntze subsp. glandulosum (Req.) Govaerts (Sümüklü Fesleğen)}

75 cm'ye kadar boylanabilen çok yıllık otlar. Yapraklar yumurtamsı. Çiçek durumları (2-)5-15 çiçekli. Korolla leylaktan pembe'ye kadar değişen renklerde. Meyve fındıksı. Haziran-Ekim aylarında çiçeklenen bu alt tür, yetişme ortamı olarak deniz seviyesinden 1200 m'ye kadar olan yüksekliklerdeki kumlu ve kayalık kireçtaşı yamaçlarını, tarlaları, nehir yataklarını ve kayın-kestane ormanlarını tercih eder. Avr.-Sib. El. 


\section{Clinopodium vulgare L. subsp. arundanum (Boiss.) Nyman (Kamış Fesleğen)}

Hemen hemen dik gövdeli, tüylü 20-70 cm boyunda, çok yıllık otsu bitkiler. Yapraklar yumurtamsı veya yumurtamsı-dikdörtgenimsi. Kaliks yoğun uzun tüylü. Çiçek durumları yoğun çiçekli. Korolla mor renkli. Haziran-Ağustos aylarında çiçeklenen bu alt tür, yetişme ortamı olarak, 150-2000 m'ler arasındaki nehir yataklarını, çalııkları, kuru kireçtaşı yamaçlarını ve tarlaları tercih eder. ÇBFCB.

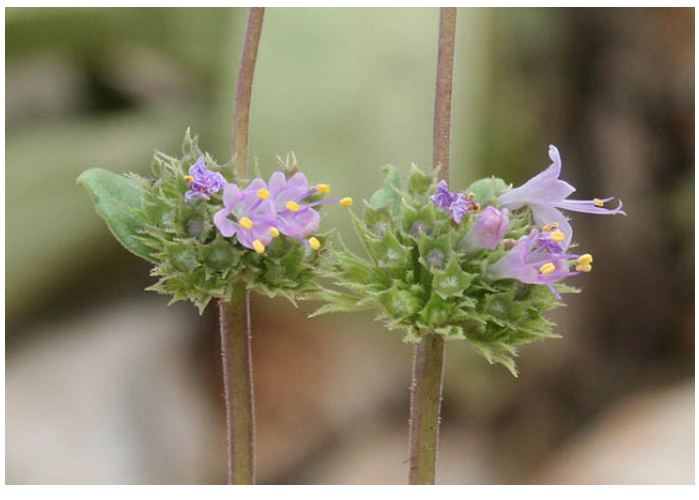

Fig. 39. Cyclotrichium origanifolium
Cyclotrichium origanifolium (Labill) Manden \& Scheng. (Dağ Nanesi) (Fig. 39)

Yarı çalımsı çok yıllık bitkiler. Gövdeler, yarı dik, eğik tırmanışlı, yatık gövdeli veya kıvrılmış. Yapraklar yumurtamsıdan yumurtamsı-dairesele kadar değişen şekillerde. Kaliks belirsiz şekilde kıvrımış. Korolla mor, menekşe veya pembe, nadiren beyaz renkli. Bu tür yetişme ortamı olarak 13002200 m’ler arasındaki dağlık kuru yamaçları, kireç taşlı kayalıkları tercih eder. Akd. El.

\section{Lamium moschatum Miller var. moschatum (Lünlüotu)}

65 cm'ye kadar boylanabilen, tüylü veya tüysüz, bir yıllık bitkiler. Yapraklar genişşe yumurtamsı, kalpsi-yumurtamsı veya yarı dairesel. Brakteler beyaz veya pembe lekeli veya yok. Korolla beyaz, tüpün alt kısmında kırmızı-mor noktalı. Korolla'nın tüp kısmı kıvrık. Fındıksı meyve ters yumurtamsı. Ülkemiz dışında Balkan ülkelerinde yayılış gösteren bu varyete, Nisan-Haziran aylarında çiçeklenir ve yetişme ortamı olarak deniz seviyesinden 500 m'ye kadar olan yüksekliklerdeki kayalıkları, yol kenarlarını ve tarlaları tercih eder. Akd. El.

\section{Melissa officinalis L. subsp. officinalis (Oğulotu) (Fig. 40)}

28-95 cm veya daha fazla boylanabilen, dik, dallı çok yıllık otsu bitkiler. Yapraklar genişçe yumurtamsı veya eliptik. Çiçek durumları tek yönlü, 412 çiçekli. Kaliks tüpsü-çansı. Korolla soluk sarı daha sonra beyaz renge döner. Fındıksı meyveler düz. Haziran-Eylül aylarında çiçeklenen bu alt tür yetişme ortamı olarak, deniz seviyesinden 700 m'ye kadar olan yüksekliklerdeki orman açıklıklarını, çalılıkları, makilik alanları, kayalık yamaçları,

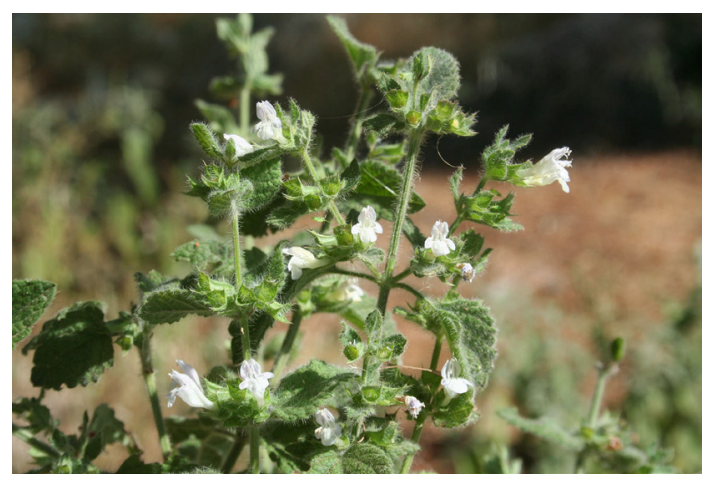

Fig. 40. Melissa officinalis subsp. officinalis nemli yerleri ve yol kenarlarını tercih eder. Avr.-Sib. El.

\section{Mentha longifolia (L.) Hudson subsp. typhoides (Briq.) Harley (Dere Nanesi)}

Kokulu, tüylü, rizomlu, 120 cm'ye kadar boylanabilen çok yıllık otlar. Yapraklar dikdörtgenimsieliptikten dikdörtgenimsi mızraksıya kadar değişen şekillerde. Korolla leylak veya beyaz renkli. Fındıksı meyve pürüzlü. Ülkemizde oldukça geniş bir yayılış alanına sahip olan bu bitki, TemmuzEkim aylarında çiçeklenir. Yetişme ortamı olarak 900-2135 m’ler arasındaki bataklık alanları, ırmak ve nehir kenarlarını tercih eder. ÇBFCB. 


\section{Nepeta nuda L. subsp. albiflora (Boiss.) Gams (Karaküncü)}

Dik gövdeli, $20-90 \mathrm{~cm}$ boyunda çok yıllık otsu bitkiler. Yapraklar yumurtamsıdan yumurtamsı-dikdörtgenimsiye kadar değişen şekillerde. Kaliks çiçekte tüpsü, meyvede yumurtamsı. Korolla beyaz, krem veya menekşe-mavi renkli. Fındıksı meyve yumurtamsı-dikdörtgenimsi. Ülkemizin hemen hemen tüm bölgelerinde yayılış gösteren bu alt tür, Mayıs-Ağustos aylarında çiçeklenir. Yetişme ortamı olarak ise kayalık yamaçları, tarla kenarları ve kireçtaşı kayalıkları tercih eder. ÇBFCB.

\section{Origanum minutiflorum O. Schwarz \& P. H. Davis (Toka Kekik) (Türkiye Endemiği)}

$35 \mathrm{~cm}$ 'ye kadar boylanabilen yarı çalılar. Yapraklar yumurtamsı veya eliptik. Kaliks yaklaşık $2 \mathrm{~cm}$ boyunda. Korolla beyaz 2,5-4 cm boyunda. Antalya ve Isparta illerine özgü olan bu tür, TemmuzAğustos aylarında çiçeklenir. Yetişme ortamı olarak ise 1500-1800 m’ler arasındaki kayalık kireçtaşlı yamaçları tercih eder. Akd. El.

\section{Phlomis lycia D. Don (Tüylü Çalba) (Fig. 41)}

1.5 m’ye kadar boylanabilen çalılar. Yapraklar yoğun basık yıldızsı tüylü, dikdörtgenimsi-mızraksı, tabanda kalpsi. Çiçek durumları 6-12 çiçekli. Kaliks 10-12 mm boyunda. Korolla sarı renkli. Fındıksı meyve çıplak. Yetişme ortamı olarak deniz seviyesinden 900 m'ye kadar olan yüksekliklerdeki makilikleri, meşe çalııklarını, kızılçam ormanlarını ve serpantin alanları tercih eden bu tür, Mayıs-Ağustos aylarında çiçeklenir. Akd. El.

Salvia argentea L. (Boz Şalba) (Fig. 42)

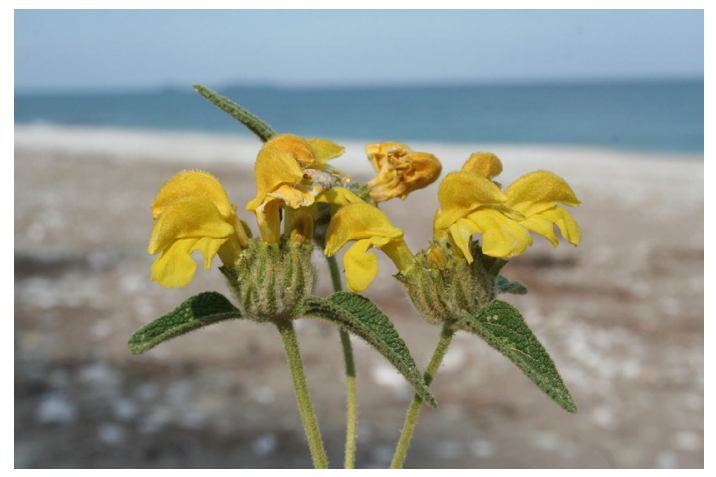

Fig. 41. Phlomis lycia

20-100 cm boyunda çok yıllık otsu bitkiler. Yapraklar çoğunlukla tabanda yumurtamsıdan dikdörtgenimsiye kadar değişen şekillerde. Korolla beyaz renkli, üst dudak menekşe renkli ve geniş. Nisan-Temmuz aylarında çiçeklenen bu gümüşi adaçayı yetişme ortamı olarak 300-2000 m’ler arasındaki kireçtaşlı kayalıkları, çam ormanlarını ve kayalık yerleri tercih eder. Akd. El.

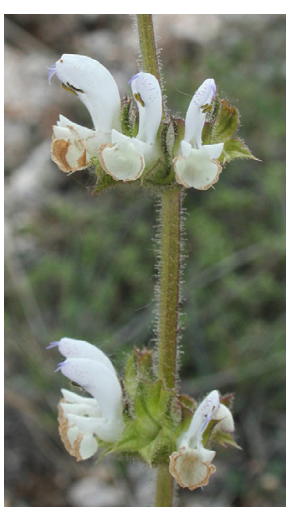

Fig. 42. Salvia argentea

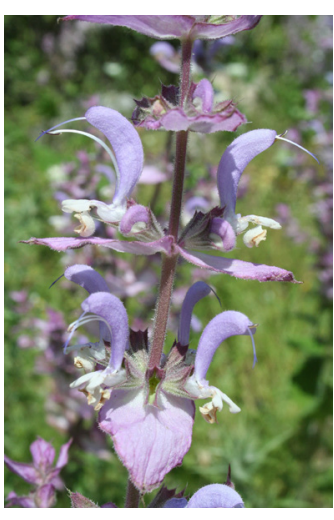

Fig. 43. Salvia sclarea

Salvia sclarea L. (Paskulak) (Fig. 43)

İki yıllık veya kısa ömürlü çok yıllık bitkiler. Gövde üst kısımda dallı, $1 \mathrm{~m}$ boyunda. Yapraklar basit, genişçe yumurtamsıdan yumurtamsı-dikdörtgenimsiye kadar değişen şekillerde. Çiçek durumları 2-6 çiçekli. Brakteler geniş, pembemsi-mor renkli. Kaliks yumurtamsıçansı. Korolla leylak renkli. Meyve fındıksı. Ülkemizde oldukça geniş bir yayılış alanına sahip olan bu tür, Mayıs-Eylül aylarında çiçeklenir. Yetişme ortamı olarak ise deniz seviyesinden 2000 m'ye kadar olan yüksekliklerdeki kayalık yamaçları, karışık yaprak döken veya iğneli ormanlıkları ve yol kenarlarını tercih eder. ÇBFCB.

\section{Salvia verticillata L. subsp. amasiaca (Freyn \& Bornm.) Bornm. (Dadırak)}

15-70 cm boyunda, dik veya eğik tırmanışlı çok yıllık otlar. Yapraklar basit, dikdörtgenimsiden yumurtamsıya kadar değişen şekillerde veya lirat parçalı. Çiçek durumları (8-)20-40 çiçekli. Kaliks 
tüpsü. Korolla menekşe-mavi leylak veya nadiren beyaz renkli. Meyve fındıksı. 1899 yılında Amasya'dan toplanarak bilim dünyasına 1908 yılında tanıtılan bu bitki Nisan-Eylül aylarında çiçeklenir. Yetişme ortamı olarak ise 20-2300 m'ler arasındaki kayalık yamaçları, çayırlıkları, kumlu yerleri, meşe ve çam ormanlarını, tarlaları ve yol kenarlarını tercih eder. Ir.-Tur. El.

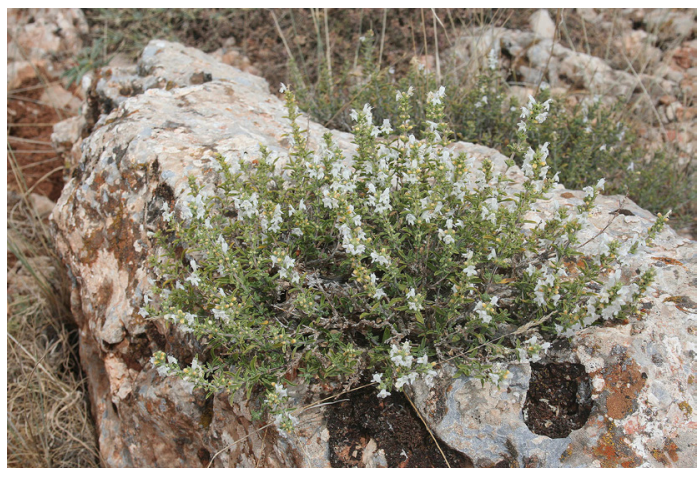

Fig. 44. Satureja cuneifolia

\section{Satureja cuneifolia Ten. (Kayakekiği) (Fig. 44)}

Yarı çalımsı, dik veya eğik tırmanışlı, $12-40 \mathrm{~cm}$ boyunda çok yıllık bitkiler. Yapraklar kamamsı-ters mızraksı. Çiçek durumları 2(-6) çiçekli. Kaliks 3-4,5 $\mathrm{mm}$ boyunda. Korolla beyaz, nadiren leylak renkli. Meyve fındıksı. Illk kez Italya'dan toplanarak bilim dünyasına tanıtılan bu tür, yetişme ortamı olarak 300-2000 m'ler arasındaki kayalık yamaçları şistli ve kireçtaşlı alanları tercih eder. Akd. El.

\section{Scutellaria brevibracteata Stapf. subsp. brevibracteata (Yağlı Kaside) (Türkiye Endemiği)}

50 cm'ye kadar boylanabilen, dik ve çok dallı çok yıllık bitkiler. Yapraklar saplı, genişçe yumurtamsı-üçgenimsi. Çiçekler morumsu veya kırmızımsı-menekşe renkli. Ülkemize özgü olan bu alt tür, Antalya ve Muğla illerinde yayılış göstermektedir. Mayıs-Ağustos aylarında çiçeklenen bu bitki yetişme ortamı olarak deniz seviyesinden 400 m'ye kadar olan yüksekliklerdeki kayalık yamaçları, sedir ve ardıç ormanlarını, makilikleri ve kireçtaşı kayalıklarını tercih eder. Akd. El.

\section{Sideritis albiflora Hub.-Mor. (Akçiçekçayı) (Türkiye Endemiği) (Fig. 45)}

Yoğun basık beyaz keçemsi tüylü, 60 cm'ye kadar boylanabilen çok yıllık otsu bitkiler. Gövde yaprakları şeritsi-dikdörtgenimsi. Kaliks 7-9 mm boyunda. Korolla beyaz renkli. Fındıksı meyve yumurtamsı. Antalya ve Muğla illerine özgü olan bu beyaz çiçekli adaçayı türü, Mayıs-Temmuz aylarında çiçeklenir. Yetişme ortamı olarak ise deniz seviyesinden 800 m'ye kadar olan yüksekliklerdeki makilikleri, meşe çalılıklarını ve

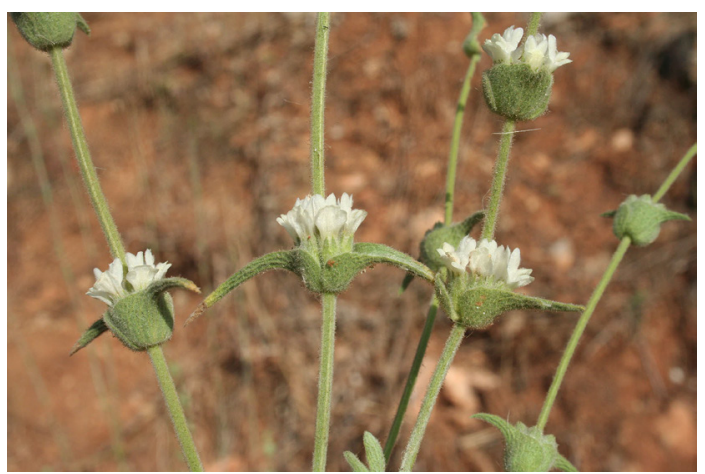

Fig. 45. Sideritis albiflora kireçtaşı yamaçlarını tercih eder. Akd. El.

\section{Sideritis libanotica Labill. subsp. linearis (Bentham) Bornm. (Torosçayı)}

Basit veya dallı, 1 m’ye kadar boylanabilen çok yıllık otsu bitkiler. Gövde yaprakları şeritsiden mızraksıya kadar değişen şekillerde. Çiçek durumları 6 çiçekli. Kaliks 5.5-9 mm boyunda. Korolla sarı renkli. Fındıksı meyve yumurtamsı. Yetişme ortamı olarak 1100-2800 m'ler arasındaki kireçtaşı kayalıklarını, kuru yamaçları ve stebi tercih eder. Çiçeklenme zamanı Mayıs-Eylül ayları olan bu alt tür ülkemize özgüdür. Akd. El.

Stachys Iavandulifolia Vahl. subsp. Iavandulifolia (Tüylü Çay) (Fig. 46)

Yarı çalı çok yıllık otsu bitkiler. Gövde 10-30 cm boyunda, seyrek veya yoğun uzun tüylü. Alt yapraklar dikdörtgenimsi-mızraksıdan ters mızraksıya kadar değişen şekillerde. Çiçek durumları (2-)4-6 
çiçekli. Kaliks uç kısımda yumuşak dikenli. Korolla mor-leylak renkli. Fındıksı meyve ters yumurtamsı. Mayıs-Ağustos aylarında çiçeklenen bu alt tür yetişme ortamı olarak 1000-3660 m'ler arasındaki, kireçtaşı kayalık yamaçlarını ve kaya yarıklarını tercih eder. ÇBFCB.

Teucrium scordium L. subsp. scordioides (Schreb.) Arcang. (Kurtluca)

Stolonlu, dik veya eğik tırmanışlı çok yıllık otsu bitkiler. Yapraklar dikdörtgenimsiden yumurtamsı-dikdörtgenimsiye kadar değişen şekillerde. Kaliks 3-5 mm boyunda. Korolla morumsu-pem-

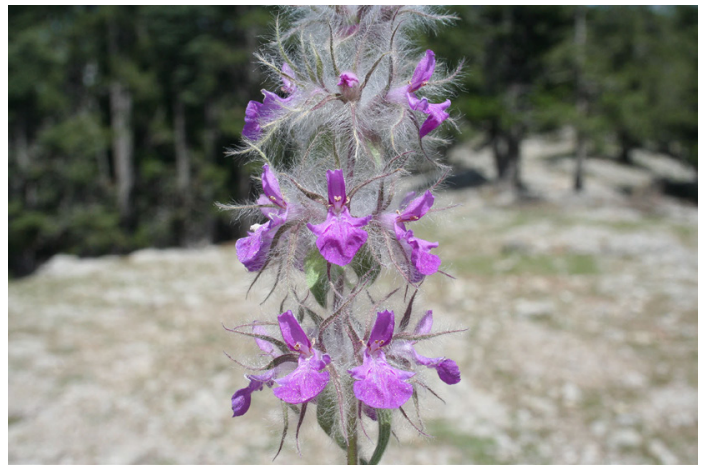

Fig. 46. Stachys lavandulifolia subsp. lavandulifolia be veya leylak renkli. Meyve fındıksı. Bu alt tür Mayıs-Eylül aylarında çiçeklenmekte olup 502350 m'ler arasındaki tatı veya az tuzlu bataklıkları ve tarlaları tercih eder. Avr.-Sib. El.

\section{Thymbra spicata L. subsp. spicata (Zahter)}

40 cm'ye kadar boylanabilen çalılar. Çiçekli gövdeler dik veya eğik tırmanışlı. Yapraklar şeritsi veya şeritsi-mızraksı. Çiçek durumu 1-8 (-10) cm boyunda, yumurtamsı veya dikdörgenimsi. Kaliks 4-6 $\mathrm{mm}$ boyunda. Korolla mor, pembe veya leylak renkli. Meyve fındıksı. Bu varyete yetişme ortamı olarak deniz seviyesinden 1000 m’ye kadar olan yüksekliklerdeki kuru kayalık yerleri, çalılık alanları, friganayı ve stebi tercih eder. Çiçeklenme zamanı ise Haziran ve Temmuz aylarıdır. Akd. El.

\section{Thymus revolutus Célak (Kum Kekiği) (Türkiye Endemiği) (Fig. 47)}

Odunlu bodur, çalılar. Çiçekli gövde 2-9 cm boyunda, dik, tüylü. Yapraklar mızraksı-oraksı. Çiçek durumu konik-kompakt. Kaliks 4-5 mm boyunda. Korolla mor renkli. Meyve fındıksı. Ülkemize özgü olan bu tür, sadece Antalya ve Mersin illerinde yetişmektedir. Mayıs-Temmuz aylarında çiçeklenen bu kekik türü, yetişme ortamı olarak deniz seviyesinden 1000 m'ye kadar olan yüksekliklerdeki kayalık açıklıkları tercih eder. Akd. El.

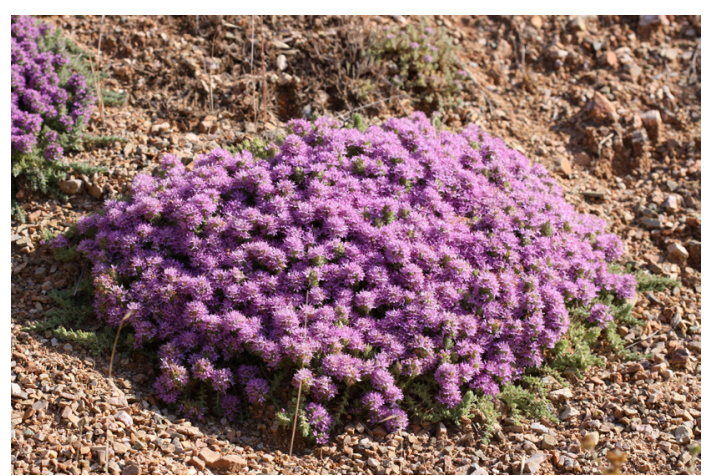

Fig. 47. Thymus revolutus

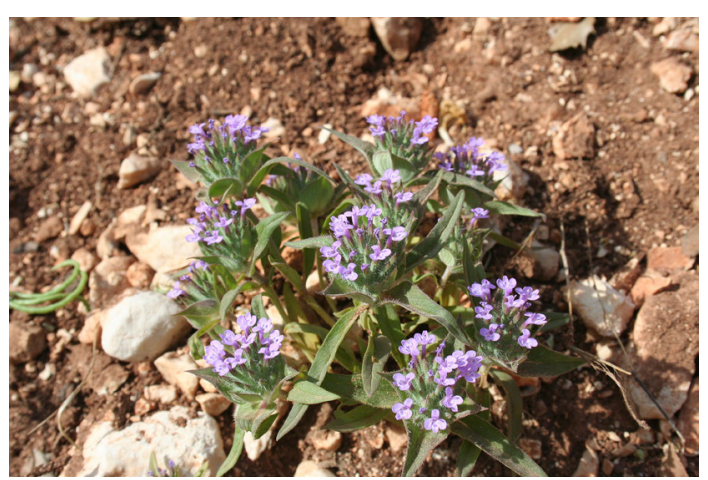

Fig. 48. Ziziphora capitata

\section{Ziziphora capitata L. (Anuk) (Fig. 48)}

Tüylü, 4-15 cm boyunda, basitten çok dallıya kadar değişen şekillerde, bir yıllık otsu bitkiler. Yapraklar şeritsi-mızraksıya kadar değişen şekillerde. Kaliks 8-11 mm boyunda. Korolla menekşe, mor veya lavanta renkli. Fındıksı meyve yumurtamsı. Bu tür yetişme ortamı olarak deniz seviyesinden 2200 m'ye kadar olan yüksekliklerdeki kuru açık alanları, taşlı yamaçları, ve stebi tercih eder. Çiçeklenme zamanı ise Nisan ve Ağustos aylarıdır. ÇBFCB. 
Familya: Linaceae (Ketengiller)

Linum virgultorum Boiss. \& Heldr. ex Planch. (Güdün)

Narin yapılı, bir yıllık otsu bitkiler. Gövde dik $20-40 \mathrm{~cm}$ boyunda, dallı. Yapraklar mızraksı. Sepaller yumurtamsı-mızraksı. Petaller mavi renkli, 15-16 mm boyunda. Kapsül meyve 5-6 mm boyunda. Tip örneği Antalya olan bu tür, 1849 yılında bilim dünyasına tanıtılmıştır. 50-400 m’ler arasındaki serpantin kayalıklarda, kalkerli kayalık yamaçlarda ve kızılçam ormanlarında yetişir. Çiçeklenme zamanı ise Nisan-Mayıs aylarıdır. Akd. El.

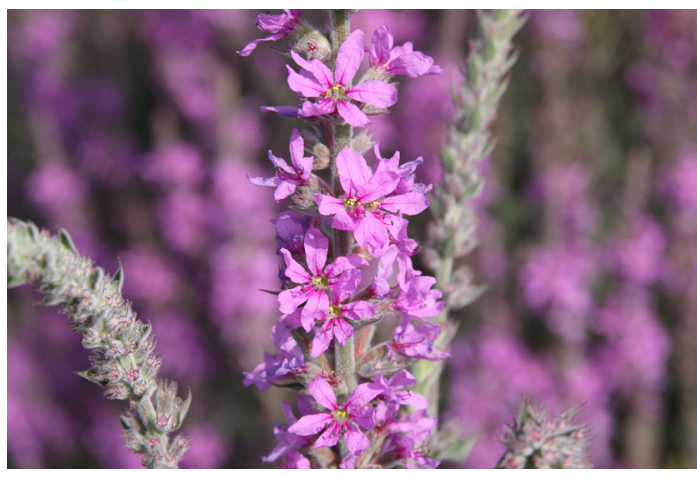

Fig. 49. Lythrum salicaria
Familya: Lythraceae (Aklarotugiller)

Lythrum salicaria L. (Hevhulma) (Fig. 49)

180 cm'ye kadar boylanabilen, sağlam yapılı, çok yıllık otsu bitkiler. Yapraklar yumurtamsıdan darca mızraksıya kadar değişen şekillerde. Başak çiçek durumu yoğun. Petaller mor renkli. Kapsül meyve yumurtamsı. Haziran-Ağustos aylarında çiçeklenen bu tür, yetişme ortamı olarak 100-2000 m'ler arasındaki akarsu kenarlarını ve nemli yerleri tercih eder. Avr.-Sib. El.

Familya: Malvaceae (Ebegümecigiller)

\section{Althaea cannabina L. (Gülhannaz)}

Çok yıllık otsu bitkiler. Gövde dik, küçük yıldızsı tüylü. Yapraklar 3-5 loplu; loplar dikdörtgenimsiden mızraksıya kadar değişen şekillerde. Epikaliks segmentleri 6-9 adet. Sepal 5-6 mm boyunda. Petaller 11-16 mm boyunda, pembe renkli. Merikarp meyve tüysüz. Haziran-Ağustos aylarında çiçeklenen bu tür, yetişme ortamı olarak deniz seviyesinden 1250 m'ye kadar olan yüksekliklerdeki bataklık alanları ve nemli yerleri tercih eder. ÇBFCB.

\section{Malva nicaeensis All. (ilmikotu) (Fig. 50)}

Bir yıllık otsu bitkiler. Gövde dik veya eğik tırmanışlı, seyrek setoz tüylü. Yapraklar hemen hemen dairesel, hafif 5-7 loplu. Sepaller genişçe üçgenimsi. Petaller leylak-pembe. Meyve merikarp. Ülkemizde Marmara, Ege ve Akdeniz Bölgelerinde yayılış gösteren bu tür, Nisan-Haziran aylarında çiçeklenir. Yetişme ortamı olarak deniz seviyesindeki tarlaları tercih eder. ÇBFCB.

Familya: Oleaceae (Zeytingiller)

Fraxinus ornus L. subsp. cilicica (Lingelsh) Yalt. (Dişbudak) (Türkiye endemiği)

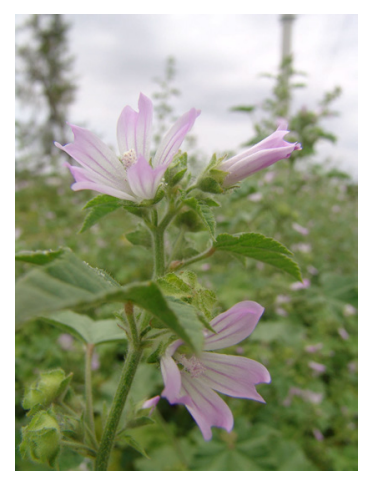

Fig. 50. Malva nicaeensis

20 m’ye kadar boylanabilen ağaçlar. Yaprakçıklar yumurtamsıdan mızraksıya kadar değişen şekillerde. Bileşik salkım çiçek durumu geniş. Çiçekler güzel kokulu, krem renkli. Samara meyve şeritsi-ters mızraksı. Nisan ve Mayıs aylarında çiçeklenen ve ülkemize özgü olan bu tür (600-)9001450(-2300) m'ler arasındaki yaprak döken çalııkları ve ağaçlıklıkları ve kireç taşlı kayalıkları tercih eder. Akd. El. 
Familya: Onagraceae (Yakıotugiller)

Ludwigia peploides (Kunth) P. H. Raven (Göl Toynakotu) (Fig. 51)

Beyaz balon şeklinde hava keselerine sahip, 1,5 m'ye kadar boylanabilen çok yıllık otsu bitkiler. Genç yapraklar mızraksı, yaşlı yapraklar dikdörtgenimsi. Çiçekler tek ve yaprak koltukarında. Sepaller 5 adet. Petaller limon sarısı renginde. Meyve kapsül. Ülkemizde sadece Antalya'da yetişen bu tür, ülkemiz dışında ise Güneydoğu Asya, Avustralya, Yeni Zelanda, Tahiti, Güney ve Kuzey Amerika'da yayılış gösterir. Yetişme ortamı olarak deniz seviyesindeki nehirleri tercih eder. Avr.-Sib. El.

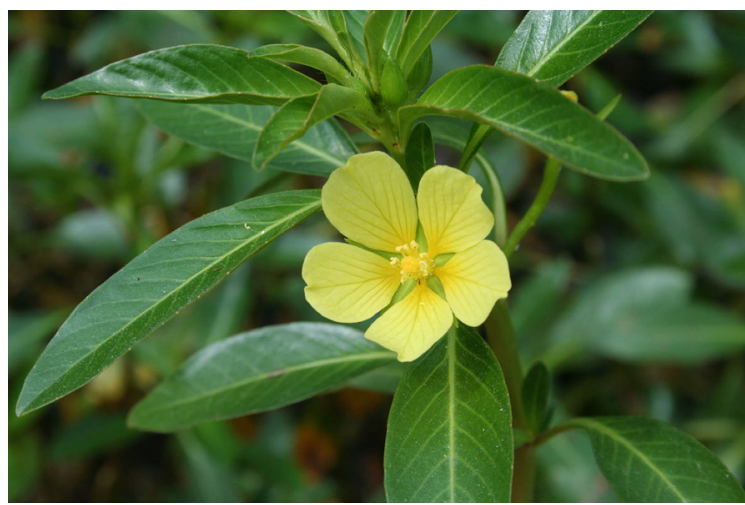

Fig. 51. Ludwigia peploides

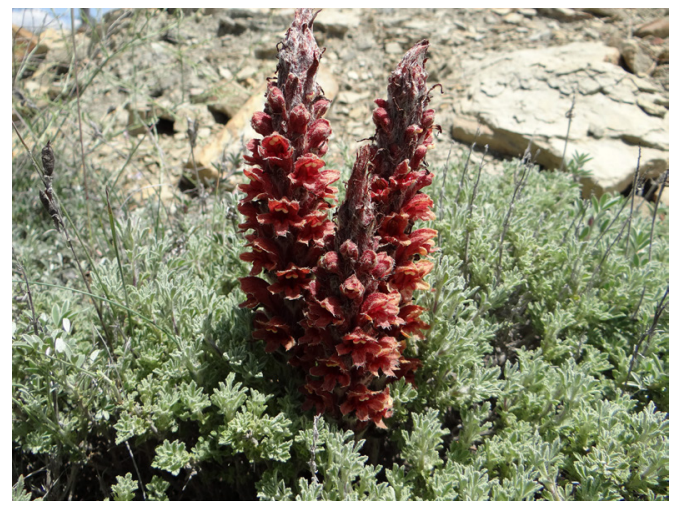

Fig. 52. Orobanche fuliginosa

Familya: Orobanchaceae (Canavarotugiller)

Orobanche fuliginosa Reut. ex Jard. (İsli Canavarotu) (Fig. 52)

15-37 cm boyunda parazit bitkiler. Brakteler çiçeklerden kısa veya eşit boyda. Kaliks yarıya kadar bölünmemiş veya iki dişli. Korolla 15-18 mm boyunda, silindirik, kırmızımsı, sarı, menekşe-kahve renkli veya menekşe renkli. Meyve kapsül. Bu tür ülkemizde Rize, Manisa, Antalya, Isparta ve Mersin illerinde, ülkemiz dışında ise Güney Avrupa'da yayılış gösterir ve 1600-2600 m’ler arasında yetişir. Akd. El.

\section{Parentucellia latifolia (L.) Caruel subsp. Iatifolia (Üçdilotu)}

Salgılı tüylü, dik gövdeli, 30 cm'ye kadar boylanabilen bir yıllık otsu bitkiler. Yapraklar yumurtamsı. Kaliks tüpsü. Korolla kırmızımsı-mor veya pembe renkli. Meyve kapsül. Nisan-Haziran aylarında çiçeklenen bu bitki, yetişme ortamı olarak deniz seviyesinden 1400 m’ye kadar olan yüksekliklerdeki kireçtaşı kayalıkları, makilikleri, çimenlikleri ve ormanları tercih eder. Akd. El.

\section{Pedicularis cadmea Boiss. (Has Bitotu)}

(Türkiye Endemiği) (Fig. 53)

Çok yıllık otsu bitkiler. Gövde dik veya eğik tırmanışlı, çok sayıda, morumsu renkli. Yapraklar dar dikdörtgenimsi, 1(-2) pinnatisekt parçalı. Kaliks tüpsü. Korolla pembeden mora kadar değişen renklerde. Kapsül meyve dikdörtgenimsi. Ülkemize özgü olan bu tür, ilk kez Denizli'den toplanarak bilim dünyasına tanıtılmıştır. Mayıs-Ağustos aylarında çiçeklenen bu bitki yetişme ortamı olarak 1600-3100 m’ler arasındaki kireçtaşlı kayalık ya-

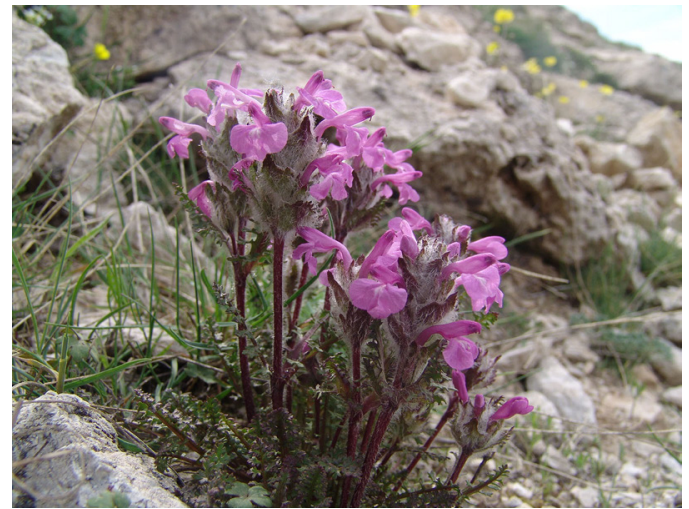

Fig. 53. Pedicularis cadmea 
maçları, uçurumları ve kaya yarıklarını tercih eder. Akd. El.

Familya: Oxalidaceae (Ekşiyoncagiller)

Oxalis pes-caprae L. (Koca Ekşi Yonca) (Fig. 54)

Çok yıllık otsu bitkiler. Yapraklar üç yaprakçıklı; yaprakçıklar ters üçgenimsi, uçta derin dişli. Sepaller yaklaşık $5 \mathrm{~mm}$ boyunda. Petaller parlak sarı renkli. Meyve kapsül. Yetişme ortamı olarak nemli yerleri ve üzüm bağlarını tercih eden bu tür, Aralık-Şubat aylarında çiçeklenir. Akd. El.

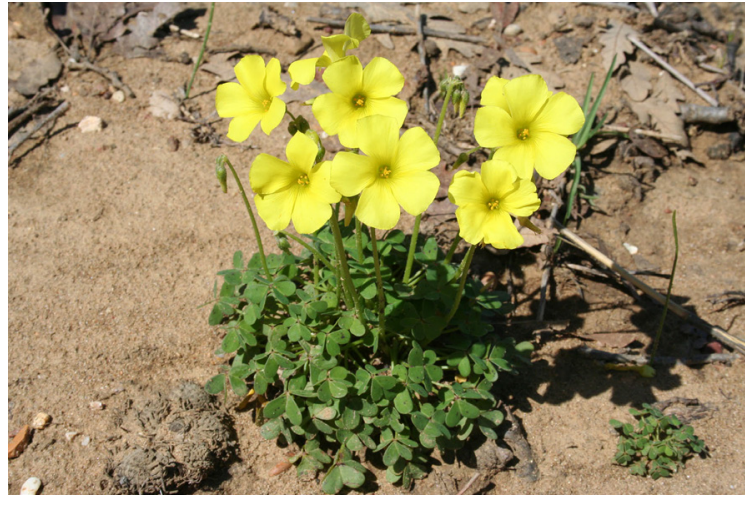

Fig. 54. Oxalis pes-caprae

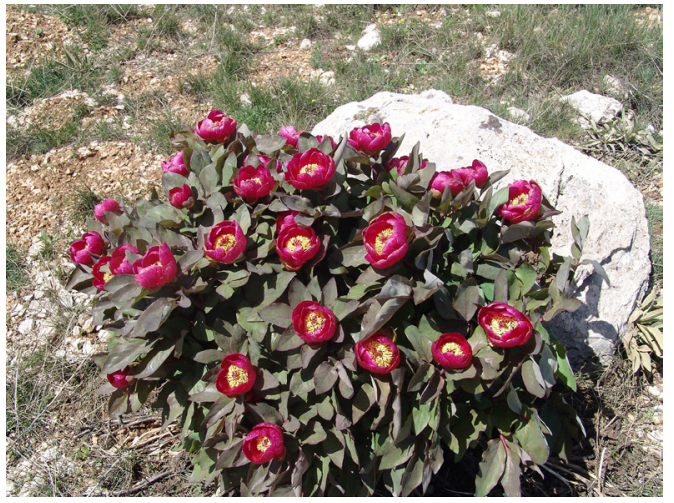

Fig. 55. Paeonia kesrouanensis

Familya: Paeoniaceae (Ayıgülügiller)

Paeonia kesrouanensis (J. Thiébaut) (Ayıgülü, Yörükgülü) (Fig. 55)

Yumrulu çok yıllık bitkiler. Alt yapraklar 9-14 segmentli; segmentler eliptik-yumurtamsı. Çiçekler küçük, 6-10 cm çapında ve kırmızı renkli. Karpeller çıplak. Folikül meyve 3-5 adet. Bu tür, ülkemizde Hatay, Antalya ve Denizli illerinde, 1800 m'ye kadar olan sedir, ardıç ormanlarını ve açıkIıkları ile kalkerli yamaçları yetişmekte ortamı olarak tercih etmekte olup, Nisan-Haziran aylarında çiçeklenmektedir. Akd. El.

\section{Familya: Papaveraceae (Haşhaşgiller)}

\section{Fumaria capreolata L. subsp. capreolata (Keçi Şahteresi)}

Sağlam yapılı otsu bitkiler. Yapraklar 2-3 pinnatisekt. Çiçek durumu sık. Brakteler şeritsi-mızraksı. Sepaller oval. Korolla beyaz, uç kısımda bordo renkli. Meyve 1 tohumlu fındık. Ülkemizde Marmara, Ege ve Akdeniz bölgelerinde yayılış gösterir ve 300 m'ye kadar olan yüksekliklerdeki nemli yerleri tercih eder. Çiçeklenme zamanı ise Nisan-Haziran aylarlıdır. ÇBFCB.

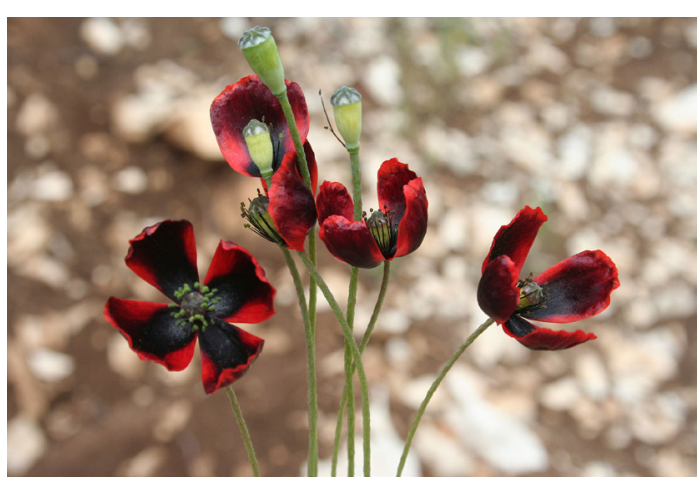

Fig. 56. Papaver dubium subsp. dubium
Papaver dubium L. subsp. dubium (Köpekyağı) (Fig. 56)

Dik gövdeli, 60 cm'ye kadar boylanabilen bir yıllık otsu bitkiler. Yapraklar pinnatisekt parçalı. Petaller 2-4 cm, soluk kırmızı. Kapsül meyve yumurtamsı-dikdörtgenimsi. 1000 m'ye kadar olan yüksekliklerdeki nemli yerleri ve tarlaları yetişme ortamı olarak tercih eder ve çiçeklenme zamanı ise Nisan-Haziran aylarında çiçeklenir. ÇBFCB. 
Papaver pilosum Sibth. \& Sm. subsp. spicatum (Boiss. \& Balansa) N. Wendt ex Kadereit (Dağ Gelinciği) (Türkiye Endemiği) (Fig. 57)

Tümüyle beyaz-pannoz tüylü çok yıllık otsu bitkiler. Gövde sağlam yapılı (3-) 60-75 cm boyunda. Yapraklar dikdörtgenimsiden dar eliptiğe kadar değişen şekillerde. Petaller turuncukırmızı renkli. Kapsül meyve tüylü. Ülkemize özgü olan bu alt tür, Temmuz ayında çiçeklenir ve 1400-1800 m'ler arasındaki kayalık yerlerde yetişir. ÇBFCB.

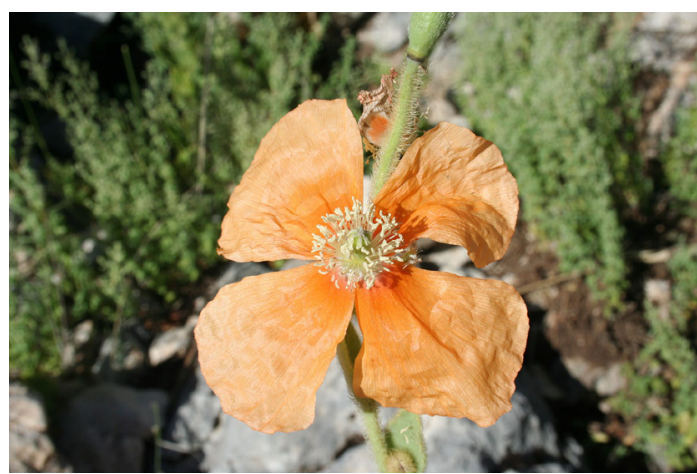

Fig. 57. Papaver pilosum subsp. spicatum

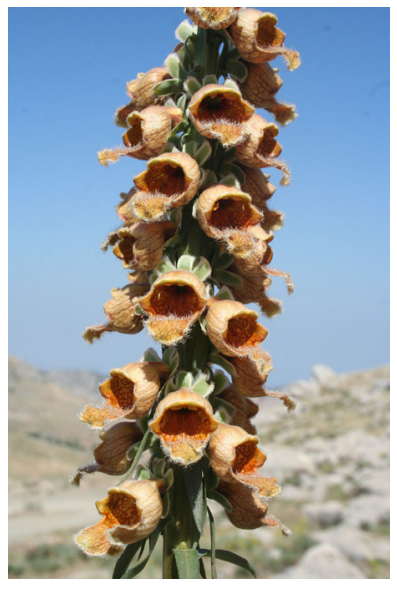

Fig. 58. Digitalis ferruginea subsp. ferruginea

Familya: Plantaginaceae (Sinirotugiller)

Digitalis ferruginea L. subsp. ferruginea (Arı Kovanı) (Fig. 58)

Sağlam yapılı, iki veya çok yıllık otsu bitkiler. Gövde çoğunlukla tek, 1 m’ye kadar boylanır. Gövde yaprakları dikdörtgenimsiden dikdörtgenimsi-mızraksıya kadar değişen şekillerde veya şeritsi. Çiçek durumu uzun ve çok çiçekli. Korolla sarımsı, kahve renkli damarlı, tüp şişkin. Kapsül meyve tüysüz. Haziran-Ağustos aylarında çiçeklenen bu alt tür, yetişme ortamı olarak deniz seviyesinden 2700 m'ye kadar olan yüksekliklerdeki orman açıklıklarını, kayalık yamaçları ve yol kenarlarını tercih eder. Avr.-Sib. El.

\section{Globularia dumulosa O. Schwarz. (Çalı Küreçiçeği)}

(Türkiye Endemiği) (Fig. 59)

Yastık formunda, tabanda odunsu çok yıllıklar. Taban yaprakları rozetsi ve çok sayıda, $15 \mathrm{~mm}$ boyunda, genişçe eliptikten yarı dairesele kadar değişen şekillerde. Çiçek kümesi sapı çok kısa. Kapitula uç kısımda (8-)10-12(-25) mm çapında. Korolla mavi renkli. Ülkemize özgü olan bu tür, Antalya, Muğla ve Denizli illerinde yayılış göstermektedir. Temmuz ayında çiçeklenen bitki, 1800-2800 m’ler arasındaki kireç taşlı kayalıkları tercih eder. D. Akd. (dağ) El.

\section{Linaria simplex DC. (Yalın Nevruzotu)}

7-30 cm boyunda, narin yapılı bir yıllık otsu bitkiler. Yapraklar şeritsi. Kaliks lopları şeritsi-kaşıksı, salgılı tüylü. Korolla açık sarı renkli, tüp üst dudaklar menekşe-damarlı. Kapsül meyve küresel. Ülkemizde geniş bir yayılış alanına sahip olan bu nevruz otu, Nisan-Haziran (Temmuz) aylarında çiçeklenir. Yetişme ortamı olarak deniz seviyesinden 1750 m'ye kadar olan yüksekliklerdeki maki açıklıklarını, kayalık ve taşlık yerleri tercih eder. Akd. El.

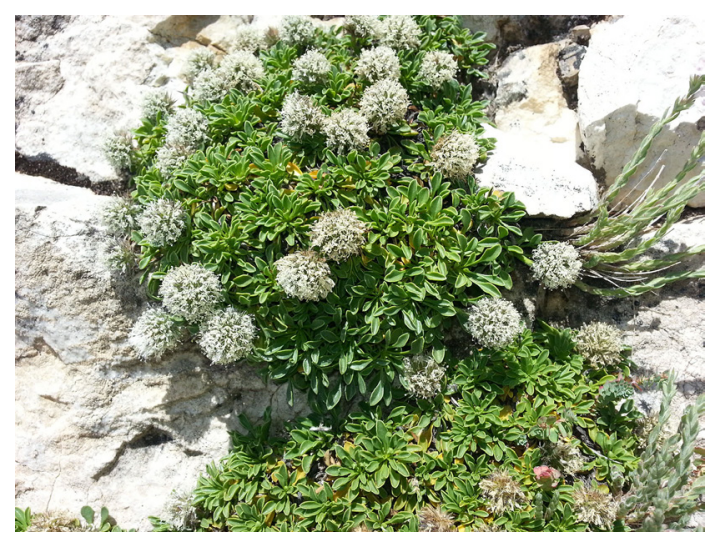

Fig. 59. Globularia dumulosa 


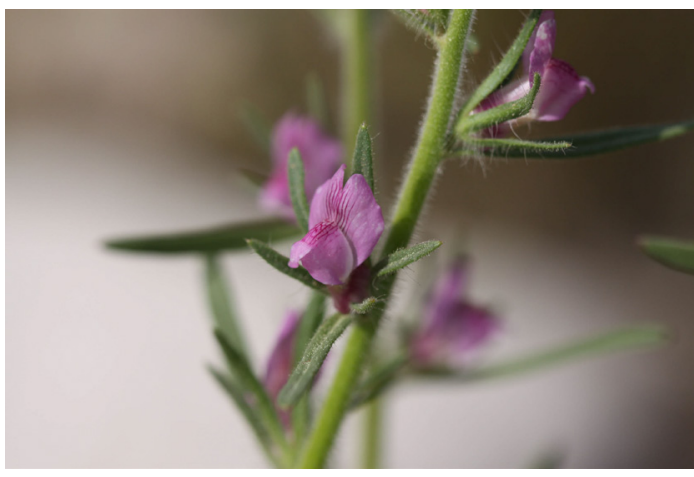

Fig. 60. Misopates orontium
Misopates orontium (L.) Raf. (Asi Balıkağzı) (Fig. 60)

Dik, 60 cm'ye kadar boylanabilen bir yıllık otsu bitkiler. Yapraklar şeritsi. Kaliks lopları şeritsi-sert kılsı tüylü. Korolla leylak-pembe renkli. Kapsül meyve 8-10 mm boyunda, salgııı tüylü. Ülkemizin batı kesimlerinde yayılış gösteren bu tür, yetişme ortamı olarak deniz seviyesinden 700 m'ye kadar olan yüksekliklerdeki kayalık kireçtaşlı yamaçları ve mezarlıkları tercih eder. Çiçeklenme zamanı ise (Mart) Nisan-Haziran aylarında çiçeklenir. ÇBFCB.

Plantago cretica L. (Bağayaprağı)

$8 \mathrm{~cm}$ 'ye kadar boylanabilen bir yıllık otsu bitkiler. Yapraklar tabanda rozetsi, şeritsi-mızraksı. Çiçek durumu başak. Öndeki sepal, eliptik ve zarımsı. Korolla tüpü geniş, loplar yumurtamsı. Kapsül meyve küresel. Nisan ve Mayıs ayında çiçeklenen bu tür, yetişme ortamı olarak deniz seviyesinden 600 m'ye kadar olan yüksekliklerdeki kireçtaşı kayalıklarını ve yamaçlarını, kumulları ve nemli alanları tercih eder. Akd. El.

\section{Veronica anagallis-aquatica L. (Sugedemesi)}

Dik ve 120 cm'ye kadar boylanabilen, çok yıllık nadiren bir yıllık otsu bitkiler. Yapraklar çıplak, yumurtamsı, eliptik veya dikdörtgenimsi. Kaliks 2-2.5 mm boyunda. Korolla lavanta, soluk mavi veya soluk leylak renkli. Kapsül meyve dairesel ve şişkin. Ülkemizde oldukça geniş bir yayılış alanına sahip olan bu tür, yetişme ortamı olarak deniz seviyesinden 2350 m’ye kadar olan yüksekliklerdeki nemi çayırları, nehir kenarlarını, bataklıkları, göl kenarlarını ve su kanallarını tercih eder. Çiçeklenme zamanı ise Mart-Eylül (Aralık) aylarıdır. ÇBFCB.

\section{Veronica syriaca Roemer \& Schultes (Arapmavişi)}

Dik gövdeli, dallı, 20 cm'ye kadar boylanabilen bir yıllık otsu bitkiler. Yapraklar genişçe yumurtamsıdan yarı dairesele kadar değişen şekillerde. Korolla mavi, merkezde beyaz renkli. Meyve kapsül. Bu tür yetişme ortamı olarak deniz seviyesinden 1200 m'ye kadar olan yüksekliklerdeki çam ormanlarını, makilikleri, kayalık yamaçları ve tarlaları tercih eder. Çiçeklenme zamanı ise Şubat-Mayıs aylarını tercih eder. Akd. El.

\section{Familya: Plumbaginaceae (Kardikenigiller)}

Plumbago europaea L. (Karakına) (Fig. 61)

Dik gövdeli, 100 cm'ye kadar boylanabilen çok yıllık otsu bitkiler. Yapraklar sarmal dizilişli, basit. Kaliks tüpsü, 6-10 mm boyunda. Korolla menekşe-gül renkli; dudaklar tekerleksi. Ülkemizde oldukça geniş bir yayılış alanına sahip olan bu tür, Temmuz-Eylül aylarında çiçeklenir ve 10-1900 m'ler arasındaki kuru yamaçlarda, kireçtaşlı kayalıklarda, tarlalarda ve nemli yerlerde yetişir. Avr.Sib. El.

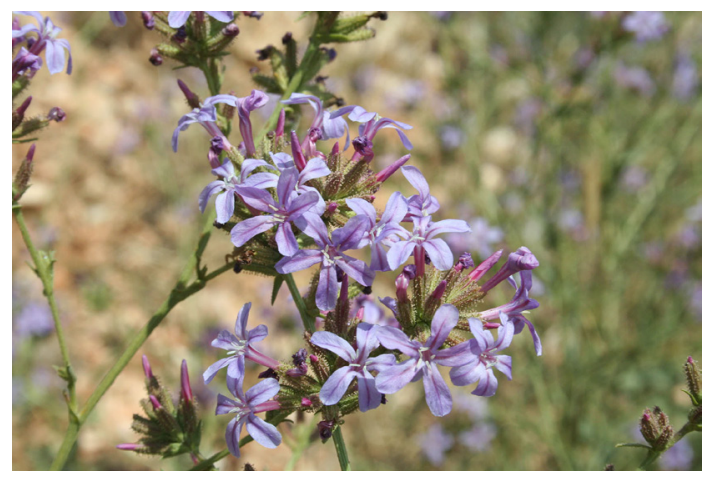

Fig. 61. Plumbago europaea 
Familya: Polygalaceae (Sütotugiller)

\section{Polygala venulosa Sibth. \& Sm. (Er Sütotu)}

Tabanda odunlu, çok yıllık bitkiler. Gövde çok sayıda, kalkık uçlu veya eğik tırmanışlı. Alt yapraklar kaşıksı veya ters mızraksı, üst yapraklar ise çok dar eliptik. İçteki sepaller beyaz veya leylak renkli. Kapsül meyve ters kalpsi, sapsız. Şubat-Mayıs aylarında çiçeklenen bu tür, ülkemizde Antalya'da, ülkemiz dışında ise Samos, Kıbrıs ve Ege adalarında ve Yunanistan'da yetişir. Akd. El.

Familya: Polygonaceae (Madımakgiller)

\section{Atraphaxis billardieri Jaub. \& Spach var. billardieri (Teke Buğdayı)}

60 cm'ye kadar boylanabilen, dolaşık yapıı çalılar. Yapraklar parlak yeşil renkli. Eliptik-dikdörtgenimsiden yumurtamsıya kadar değişen şekillerde. Periyant 5 parçalı. Meyveli periyant pembe veya pembemsi beyaz. Meyve üçgenimsi. 1300-2600 m’ler arasındaki kayalık yamaçlarda, stepte ve kuru tarlalarda yetişen bu bitki, Mayıs-Temmuz aylarında çiçeklenir. Ir.-Tur. El.

\section{Rumex bucephalophorus L. subsp. bucephalophorus (Çipir)}

$30 \mathrm{~cm}$ 'ye kadar boylanabilen bir yıllık otsu bitkiler. Taban yaprakları kaşıksı. Çiçekler iki şekilli. Pedisel ipliksi. Periyant segmentleri dişli ve meyvede geniş. Meyve üçgenimsi fındık. Ülkemizde Marmara, Ege ve Akdeniz bölgelerinde yetişen bu alt tür Şubat-Mayıs aylarında çiçeklenir. Yetişme ortamı olarak ise deniz seviyesinden 1450 m'ye kadar olan yüksekliklerdeki tarlaları ve tepelikleri tercih eder. Akd. El.

\section{Familya: Primulaceae (Çuhaçiçeğigiller)}

\section{Anagallis arvensis L. var. caerulea (L.) Gouan (Farekulağı) (Fig. 62)}

2.7-70 (-90) cm boyunda, çıplak, bir yıllık otsu bitkiler. Gövde eğik tırmanışlı, dik veya kalkık uçlu. Yapraklar yumurtamsı-dikdörtgenimsi. Pedisel $35 \mathrm{~mm}$ boyuna kadar çıkar. Korolla mavi renkli. Mart-ağustos aylarında çiçeklenen bu varyete, yetişme ortamı olarak ise deniz seviyesinden 2440 m’ye kadar olan yüksekliklerdeki deniz kenarlarını, kültür alanlarını, toprak alanları ve kireçtaşı kayalık yamaçları tercih eder. ÇBFCB.

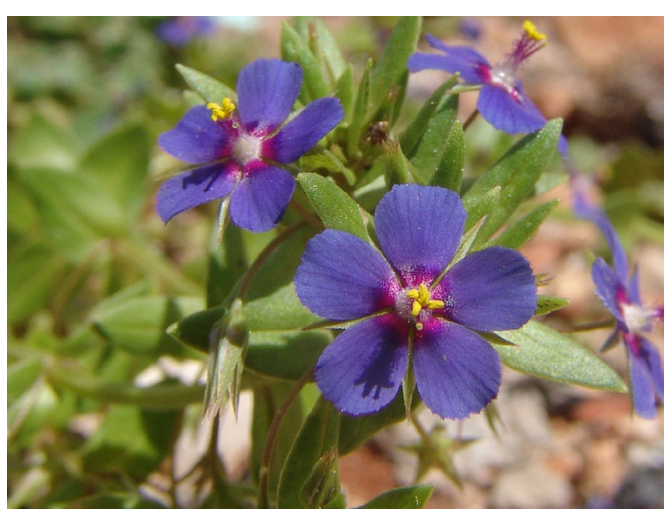

Fig. 62. Anagallis arvensis var. caerulea

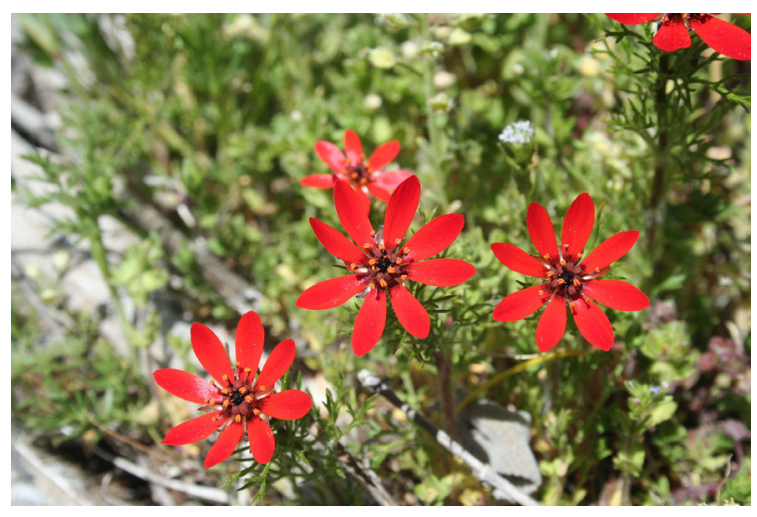

Fig. 63. Adonis aestivalis subsp. aestivalis

\section{Familya: Ranunculaceae (Düğünçiçeğigiller)}

Adonis aestivalis L. subsp. aestivalis (Kandamlası) (Fig. 63)

Tüysüz veya tabanda seyrek tüylü bir yıllık otsu bitkiler. Gövde dik, genişçe dallı, 10-50 cm boyunda. Yaprak kenarındaki yırtıklar şeritsi. Çiçekler 10-30 mm çapında. Petaller koyu kırmızı 
renkli. Aken meyve 4-5 mm boyunda. Yetişme ortamı olarak 900-1400 m’ye kadar olan yüksekliklerdeki tarlaları kayalık yamaçları ve tahrip edilmiş stebi tercih etmekte olup Nisan-Mayıs aylarında çiçeklenir. ÇBFCB.

\section{Anemone blanda Schott \& Kotschy (Dağ Lalesi) (Fig. 64)}

Hemen hemen küresel yumrulu, $25 \mathrm{~cm}$ boyunda çok yıllık otsu bitkiler. Taban yaprakları 3 parçalı. Involukral yapraklar saplı, taban yaprakları gibi 3 parçalı. Tepaller genellikle 12-15 adet, lavanta-mavisi, nadiren pembe renkli. Aken meyve tüylü. Mart-Nisan aylarında çiçeklenen bu bitki 150-2600 m’ler arasındaki, kayalık yamaçları ve çalılıkları yetişme ortamı olarak tercih eder. ÇBFCB.

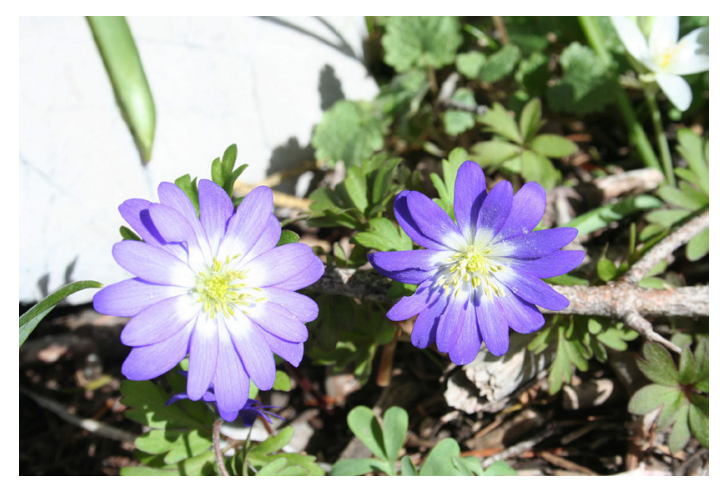

Fig. 64. Anemone blanda

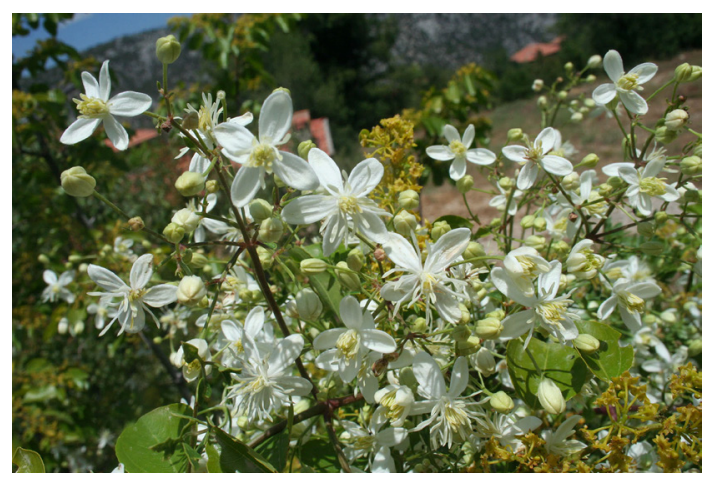

Fig. 65. Clematis flammula

\section{Clematis flammula L. (Hamilmiskin) (Fig. 65)}

Odunlu tırmanıcı, çok yıllık bitkiler. Yapraklar karşııklı dizilişli, pinnat parçalı; segmentler ternat veya biternat, en uç segment eliptik. Periyant segmentleri beyaz renkli. Aken meyve tüylü. Ülkemizde Çanakkale, İstanbul, Antalya, Adana ve Hatay illerinde yayılış gösteren bu tür, HaziranTemmuz aylarında çiçeklenir. Yetişme ortamı olarak ise 900 m'ye kadar olan makilikleri ve yamaçları tercih eder. Akd. El.

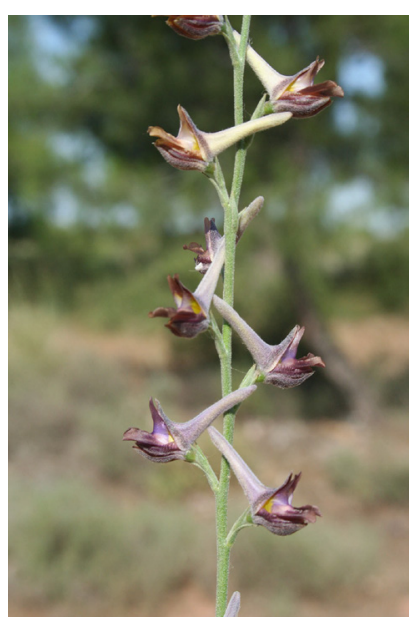

Fig. 66. Delphinium peregrinum

\section{Delphinium peregrinum L. (Tel Hezaren) (Fig. 66)}

Çubuksu bir yıllık otsu bitkiler. Gövde 10-60 cm boyunda. Orta gövde yaprak kenarlarındaki yırtıklar şeritsi şeritsi-mızraksı. Üst yapraklar şeritsi-mızraksı. Çiçekler koyu menekşe, 20-25 mm boyunda. Folikül meyve dikdörtgenimsi, 5-9 mm boyunda. Yetişme ortamı olarak deniz seviyesinden 1300 m'ye kadar olan yüksekliklerdeki kalkerli yamaçları, tarlaları ve üzüm bağlarını tercih eder. Çiçeklenme zamanı ise Haziran-Ağustos aylarıdır. Akd. El.

\section{Ranunculus constantinopolitanus (DC.) d'Urv. (Kağıthane Çiçeği)}

20-75 cm boyunda çok yıllık otsu bitkiler. Gövde genellikle yoğun sert tüylü. Köksel yapraklar tabanda kalpsi, 3-10 cm çapında. Sepaller geri dönük. Petaller sarı renkli. Aken meyve yarı dairesel. NisanHaziran aylarında çiçeklenen bu tür, yetişme ortamı olarak deniz seviyesinden 2000 m'ye kadar olan yüksekliklerdeki nemli yerleri ve bataklık alanları tercih eder. ÇBFCB. 
Ranunculus illyricus L. subsp. tenorii (Jordan) P. H. Davis (İnce Düğünçiçeği) (Fig. 67)

Narin yapılı, yarı ipeksi tüylü 20-40 cm boyunda çok yıllık otsu bitkiler. Kök yumruları dikdörtgenimsi, iğ biçimli. Yapraklar pinnatisekt parçalı; segmentler mızraksı. Petaller sarı çiçekli, 9-15 mm boyunda. Aken meyveler dairesel. Bu tür ülkemizde sadece Antalya'da, ülkemiz dışında ise italya'da yayılış gösterir. Nisan-Mayıs ayında çiçeklenen bu alt tür, yetişme ortamı olarak 250 m'ye kadar olan kızılçam orman altı ve açıklıklarını tercih eder. Akd. El.

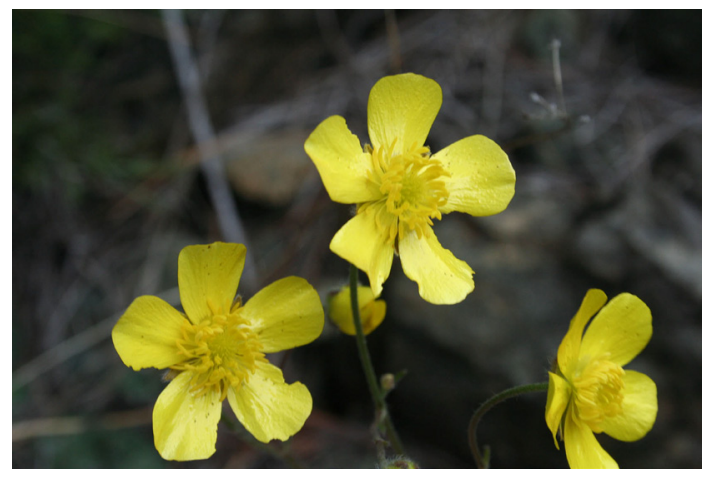

Fig. 67. Ranunculus illyricus subsp. tenorii

\section{Familya: Resedaceae (Gerdanlıkgiller)}

\section{Reseda lutea L. var. lutea (Muhabbetçiçeği)}

Bir yıllıktan çok yıllığa kadar değişen, dik veya yükselici gövdeye sahip, 70 cm'ye kadar boylanabilen bitkiler. Yapraklar üç veya pinnatisekt parçalı. Sepaller 5-6 parçalı. Petaller sarı renkli. Kapsül meyve silindirik, bazen yumurtamsı en sonunda yarı küresel. 2000 m'ye kadar olan yol kenarlarında, tarlalarda, açık taşlı tepeliklerde ve hemen hemen her yerde olan bu varyete, Nisan-Ağustos ayında çiçeklenir. ÇBFCB.

\section{Familya: Rosaceae (Gülgiller)}

\section{Amelanchier parviflora Boiss. var. dentata Browicz (Antalya Endemiği)}

2 m'ye kadar boylanabilen çalılar. Yapraklar ters yumurtamsıdan dairesele kadar değişen şekillerde, alt kısımda yoğun beyaz-keçemsi tüylü. Kaliks üçgenimsi-mızraksı. Petaller beyaz renkli. Meyve küçük üzümsü-elmamsı, yarı küresel. Tip örneği Antalya-Bozburun Dağı olan bu varyete sadece Antalya iline özgüdür. Temmuz ayında çiçeklenen bu bitki, 900-1700 m’ler arasındaki yüksekliklerde yayılış gösterir. Akd. El.

\section{Geum heterocarpum Boiss. (Sarı Arapçiçeği)}

Dik veya eğik tırmanışlı, rizomlu, 15-45 cm boyunda çok yıllık otsu bitkiler. Taban yaprakları lirat parçalı. Çiçek durumu seyrek, 3-10 çiçekli. Korolla sarı renkli. Aken meyve $15 \mathrm{~mm}$ boyunda, sert kıllı tüylü. İspanya'dan tanımlanan tür, Mayıs-Haziran aylarında çiçeklenir. Yetişme ortamı olarak ise 400-2300 m'ler arasındaki ormanlık alanlardaki gölgelik kireçtaşı kayalıkları ve ardıç altlarını tercih eder. ÇBFCB.

\section{Potentilla speciosa Willd. var. speciosa (Kaya Parmakotu) (Fig. 68)}

Dik veya eğik tırmanışlı, tabanda odunsu çok yıllık otsu bitkiler. Çiçekli gövde 5-30 cm boyunda. Yapraklar 3 yaprakçıkl; yaprakçıklar ters yumurtamsıdan genişçe yumurtamsıya kadar değişen şekillerde, üst kııımda keçemsi tüylü. Petaller sarı veya beyaz renkli. Meyve aken. Ülkemizde geniş bir yayılış alanına sahip olan bu varyete, ülkemiz dışında ise Balkanlar, Girit, Suriye ve Kuzey Irak'ta yayılış gösterir. Haziran-Ağustos ayında çiçeklenen bu bitki, 450-3200 m’ler arasındaki kireç taşlı kaya yarıklarını tercih eder. ÇBFCB. 


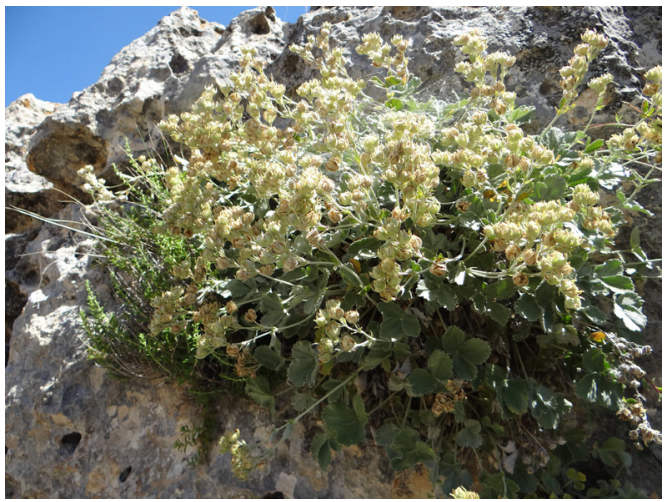

Fig. 68. Potentilla speciosa var. speciosa

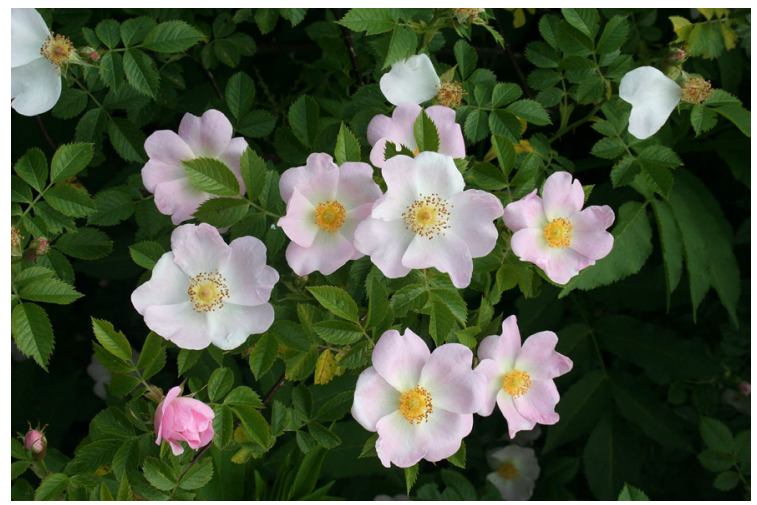

Fig. 69. Rosa canina

Rosa canina L. (Kuşburnu) (Fig. 69)

Dik veya nadiren tırmanıcı dikenli çalılar. Yapraklar 5-7 yaprakçıklı; yaprakçıklar dar eliptikten geniş yumurtamsıya kadar değişen şekillerde. Sepaller yumurtamsı. Petaller beyaz, açık pembe veya koyu pembe renkli. Çukur çiçek tablası yumurtamsıdan küresele kadar değişen şekillerde, sarımsı-kırmızı veya turuncu. Ülkemizde oldukça geniş bir yayılış alanına sahip olan bu tür, Mayıs-Temmuz aylarında çiçeklenir. Yetişme ortamı olarak ise 30-1700 (-2500) m’ler arasındaki kayalık yamaçları, çalııkları ormanları ve açıklıkları tercih eder. ÇBFCB.

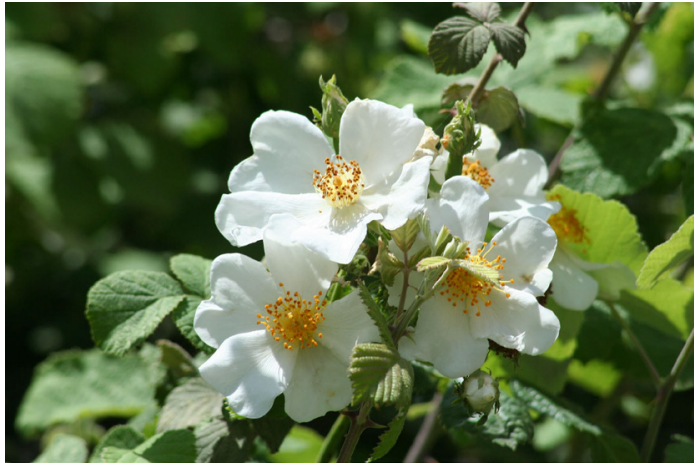

Fig. 70. Rosa phoenicia

Rosa phoenicia Boiss. (Finike Gülü) (Fig. 70)

5 m'ye kadar boylanabilen dikenli, çalılar. Yapraklar dökülücü, (3-) 5 yaprakçıklı, Yaprakçıklar oval. Petaller beyaz renkli. Çukur çiçek tablası yumurtamsı, kırmızı renkli, düz. Mayıs ve Haziran aylarında çiçeklenen bu tür, yetişme ortamı olarak 301100 m’ler arasındaki nemli yerlerdeki çalııkları ve kenarlarını tercih eder. Bu türün antik çağlarda gül yağı elde edilmesinde kullanıldığı ve Phaselis ekonomisine önemli katkılar sağladığı belirtilmektedir (Tüner-Önen 2008). Yine aynı kaynakta bir litre gül yağı elde etmek için, iki milyon gül yaprağı, yani 4-5 ton gülün işlemden geçirildiği belirtilmekte olup, kentteki güllerin oldukça büyük bir alan kapladığı düşünülmektedir. Akd. El.

\section{Sarcopoterium spinosum (L.) Spach (Abdestbozan)}

$75 \mathrm{~cm}$ veya daha fazla boylanabilen yastık formunda dikenli çalılar. Yapraklar derimsi pinnat parçalı. Sepaller yeşil renkli, yumurtamsı-dikdörtgenimsi. Üzümsü meyve hemen hemen küresel. Mart ayında çiçeklenen bu tür, taşlık yamaçları ve friganayı yetişme ortamı olarak tercih eder. Ülkemizde Akdeniz, Ege, Marmara ve Karadeniz bölgelerinde, ülkemiz dışında ise Akdeniz Havzası'nın doğu kesimlerinde ve Sardinya Adası'nda ve Tunus'ta yetişmektedir. Akd. El.

\section{Familya: Rubiaceae (Kökboyagiller)}

\section{Cruciata taurica (Pall. ex Willd.) Ehrend. (Kırım Güzeli)}

Yarı çalı veya kümemsi çok yıllık otsu bitkiler. Gövdeler 70 cm'ye kadar boylanır, dik veya eğik tırmanışlı. Yapraklar dikdörtgenimsi, dar eliptik-yarı dairesel. Korolla altın sarısımsıdan sarımsı-yeşilimsi renge kadar değişir. Merikarp tek ve küresel. 300-3300 m’ler arasındaki kuru kayalıklarda, 
stepte ve çalılıklarda yetişen bu tür, Mart-Temmuz ayında çiçeklenir. Ir.-Tur. El.

\section{Galium aparine L. (Çobansüzgeci)}

180 cm'ye kadar boylanabilen bir yıllık otsu bitkiler. Yapraklar halkasal, dar veya geniş tersmızraksı. Korolla beyazımsı. Merikarplar 3-5 mm, sert kıllı tüylü. Ülkemizde geniş bir yayılış alanına sahip olan bu tür, 30-1800 m'ler arasındaki nemli yerlerde, çalılarda ve kültür alanlarında yetişir. Çiçeklenme zamanı ise Nisan-Temmuz aylarıdır. ÇBFCB.

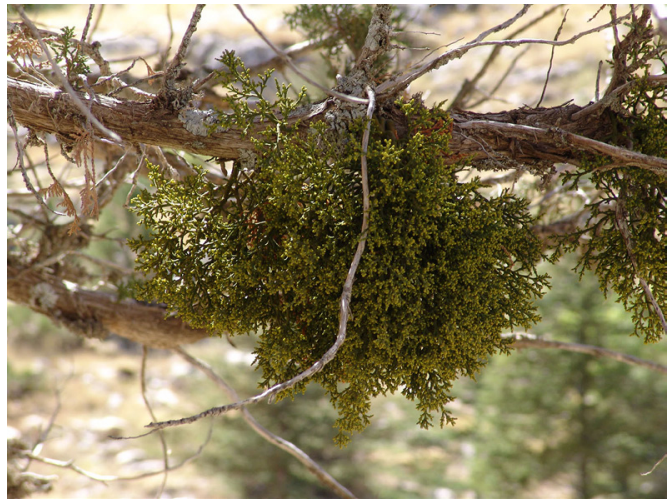

Fig. 71. Arceuthobium oxycedri
Familya: Santalaceae (Güvelekgiller)

Arceuthobium oxycedri (DC.) M. Bieb. (Ardıçgüveleği) (Fig. 71)

3-12(-20) cm boyunda, kümeli, herdem yeşil, yarı parazitik çalılar. Yapraklar pulsu, yumurtamsı, keskin sivri uçlu. Çiçekler tek veya kümeli; erkek çiçekler sapsız, segmentler yumurtamsı; dişi çiçekler kısa saplı. Üzümsü meyve yeşil renkli, yumurtamsı. Ardıç ağaçları üzerinde yarı parazit olarak yaşayan bu tür, Temmuz-Ekim aylarında çiçeklenir. Avr.Sib. El.

Familya: Saxifragaceae (Taşkırangiller)

\section{Saxifraga hederacea L. var. libanotica (Bornm.) Matthews (Cılız Taşkıran)}

Narin yapılı, eğik tırmanışlı veya kalkık uçlu bitkiler. Taban yaprakları böbreksiden genişçe yumurtamsıya kadar değişir. Sepaller dik veya yayılıcı. Petaller 2-3 mm boyunda ve soluk sarı renkli. Meyve kapsül. Mart-Haziran aylarında çiçeklenen bu varyete, 2140 m'ye kadar olan yüksekliklerdeki, gölgeli yerlerde ve kayalıklarda yetişir. ÇBFCB.

\section{Familya: Scrophulariaceae (Sıracaotugiller)}

\section{Scrophularia peregrina L. (Sahil Sıracası)}

Bir yıllık otsu bitkiler. Gövde 23-75(-100) cm boyunda, alt kısımda morumsu renkli. Yapraklar saplı, yumurtamsı veya genişçe yumurtamsı. Korolla koyu kiremit kırmızısı renkli. Kapsül meyve yumur-

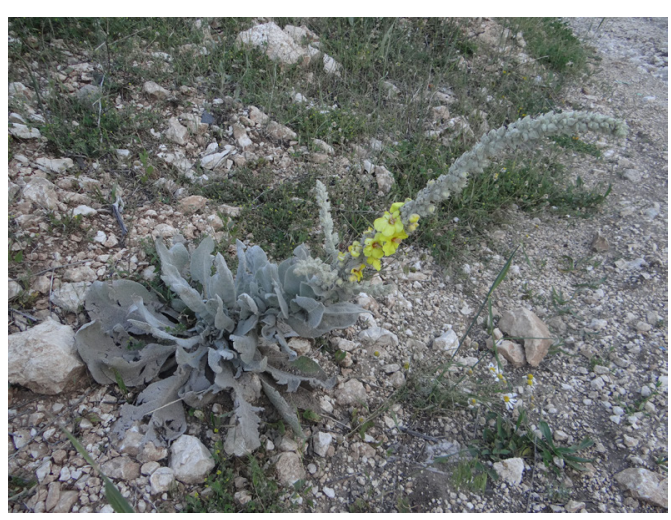

Fig. 72. Verbascum davisianum tamsı. Mart-Mayıs aylarında çiçeklenen bu tür, yetişme ortamı olarak deniz seviyesinden 290 m'ye kadar olan yüksekliklerdeki dere yataklarını, gölgelik yamaçları ve nemli yerleri tercih eder. Akd. El.

\section{Verbascum davisianum Hub.-Mor. (Kemer} Sığırkuyruğu) (Antalya Endemiği) (Fig. 72)

Sağlam gövdeli, 30-80 cm boyunda iki yıllık bitkiler. Taban yapraklar ters yumurtamsı. Çiçek durumu kompakt, silindirik. Kaliks 8-10 mm boyunda. Korolla sarı renkli ve $20 \mathrm{~mm}$ çapında. Kapsül meyve eliptik. İlk kez Türkiye Florası editörü olan Davis tarafından Tahtalı Dağ'ından toplanarak, 1952 yılında Huber-Morath tarafından bilim dünyasına tanıtılan bu tür, sadece Antalya ilinde yayılış göstermektedir. Temmuz-Ağustos aylarında çiçeklenen bu tür, 1400-2500 m’ler 
arasındaki otlak alanları ve kireçtaşı kayalık yerleri yetişme ortamı olarak tercih eder. D. Akd. (dağ) El.

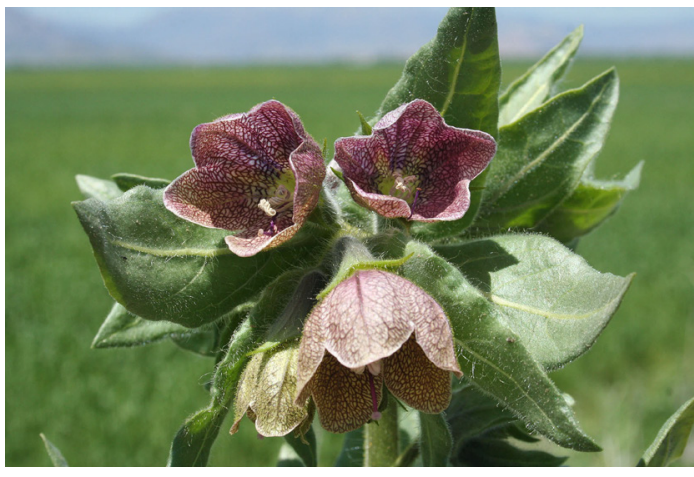

Fig. 73. Hyoscyamus reticulatus

\section{Familya: Solanaceae (Patlıcangiller)}

Hyoscyamus reticulatus L. (Kumacıkotu) (Fig. 73) 40-60 cm boyunda. Taban ve alt gövde yaprakları saplı, dikdörtgen veya dikdörtgenimsi-mızraksı, pinnat veya pinnatisekt parçalı; üst yapraklar sapsız. Kaliks çiçekte 10-20 mm boyunda, meyvede ise 20-30 $\mathrm{mm}$ boyunda ve dişler sert dikenli ve hafifçe geriye kıvrık. Korolla soluk sarımsı daha sonra morumsu-menekşe renkli ve koyu ağsı damarlı. Meyve kapsül. 10-1700 m'ler arasındaki nemli yerler, hububat tarlaları, yol kenarları ve üzüm bağlarında yetişen bu tür, Nisan-Ağustos aylarında çiçeklenir. Ir.-Tur. El.

Familya: Tamaricaceae (Ilgıngiller)

Tamarix tetrandra Pall. ex M.Bieb. (Gezik)

2-3 m boyunda çalılar veya küçük ağaçlar. Yapraklar küçük, pulsu, basit ve sarmal dizilişli. Çiçek durumu 3-6 cm boyunda. Brakteler pedisellerden uzun. Çiçekler 4 parçalı. Sepaller 0.5-1.5 mm boyunda. Petaller beyaz veya pembe renkli, $(2,2)$ 2,4-3 mm boyunda. Kapsül meyve piramidal. Mayıs ayında çiçeklenen bu tür, 1300 m’ye kadar olan yüksekliklerdeki nehir yataklarını tercih eder. ÇBFCB.

\section{Familya: Thymelaeaceae (Sıyırcıkgiller)}

\section{Daphne gnidioides Jaub. \& Spach (Sıyırcık)}

2 m'ye kadar boylanabilen dik çalılar. Yapraklar derimsi dar eliptik veya ters mıraksı. Brakteler 2-3 adet ve mızraksı. Periyant yarı kalıcı, sarımtırak. Meyve yumurtamsı, turuncu-kırmızı renkli. Yetişme ortamı olarak deniz seviyesinden 1150 m'ye kadar olan yüksekliklerdeki kireçtaşlı kayalık yamaçları, kızılçam ormanlarını, mezarlıkları ve friganayı tercih eder. Çiçeklenme zamanı ise Mayıs-Ağustos aylarıdır. Akd. El.

Familya: Urticaceae (Isırgangiller)

\section{Parietaria cretica L. (Sırçaotu)}

Dağınık veya eğik yükselici bir yıllık otsu bitkiler, Gövde 5-25 boyunda ve çok dallı. Yapraklar genişçe yumurtamsıdan genişçe eliptiğe kadar değişen şekillerde. Brakteler dikdörtgenimsi-ters yumurtamsı. Merkezdeki çiçekler dişi. Deniz kenarındaki kireçtaşlı kayalıklarda ve duvarlarda yetişen bu tür, Nisan-Haziran aylarında çiçeklenir. Akd. El.

\section{Urtica dioica L. subsp. dioica (Isırgan)}

Kaba yapılı, 30-150 cm boyunda çok yıllık otsu bitkiler. Yapraklar yumurtamsı, dişli kenarlı. Erkek ve dişi çiçekler benzer şekilli, çok dallı. Haziran-Eylül aylarında çiçeklenen bu ısırgan otu, 5002700 m'ler arasındaki ormanlarda, kayalıklarda ve nehir kenarlarında yetişir. ÇBFCB. 
Sınıf: Liliopsida (Monokotiller)

Familya: Amaryllidaceae (Nergisgiller)

Allium cyrilli Ten. (Şeytan Sarımsağı) (Fig. 74)

Çok yıllık soğanlı bitkiler. Soğanlar yumurtamsı. Gövde 50-60(-90) cm boyunda. Yapraklar 3-5 adet, geniş̧e mızraksı. Şemsiye çiçek durumu yarı küresel veya dik sütunsu kümeli. Periyant çiçekte fincanımsı; segmentler beyaz veya beyazımsı-yeşilimsi renkli. Kapsül meyve (5-) 6-7 mm. Ülkemiz dışında kuzey Italya ve Yunanistan'da yayılış gösteren bu tür, Mayıs ve Haziran aylarında çiçeklenir. Yetişme ortamı olarak deniz se-

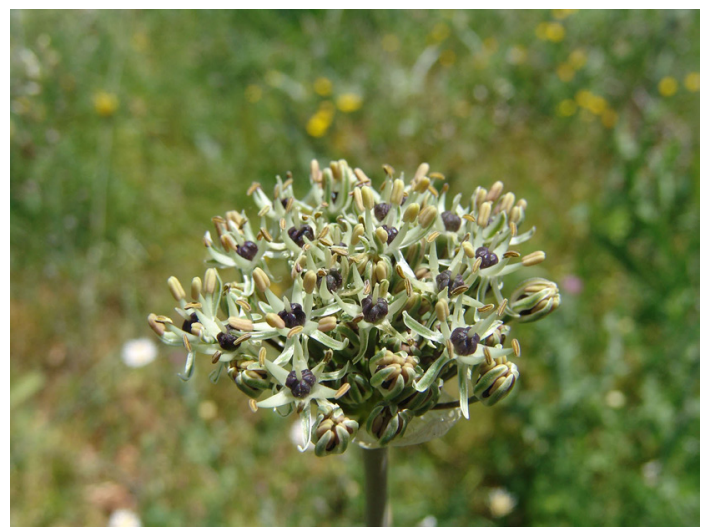

Fig. 74. Allium cyrilli viyesinden 1240 m’ye kadar olan yüksekliklerdeki tarlaları, üzüm bağlarını, nehir kenarlarını, tarla sınırlarını ve yol kenarlarını tercih eder. Akd. El.

\section{Allium subhirsutum L. (Tüylü Körmen) (Fig. 75)}

Çok yıllık soğanlı bitkiler. Soğanlar yarı küresel. Gövde 7-30 cm boyunda. Yapraklar 2-3 adet, şeritsi. Şemsiye çiçek durumu 2-7 cm çapında. Periyant segmentleri beyaz renkli. Kapsül meyve 3 mm. Bu tür yetişme ortamı olarak deniz seviyesinden 800 m'ye kadar olan yüksekliklerdeki kayın, kestane ve servi gölgeliklerini, makilik alanları ve kayalık yerleri tercih eder. Çiçeklenme zamanı ise Mart-Mayıs aylarıdır. Akd. El.

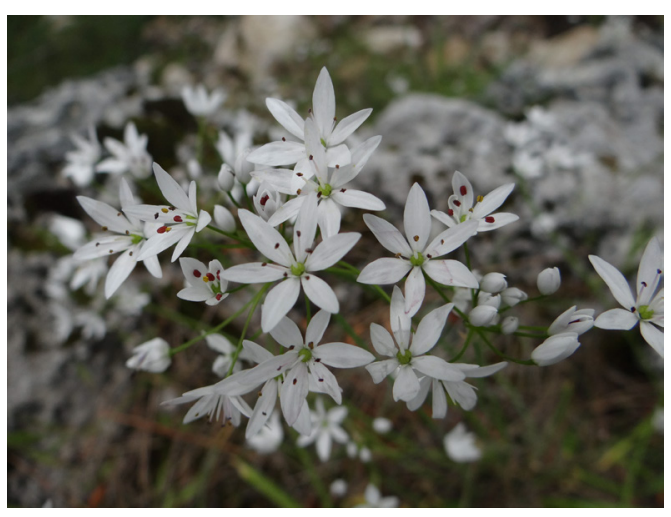

Fig. 75. Allium subhirsutum

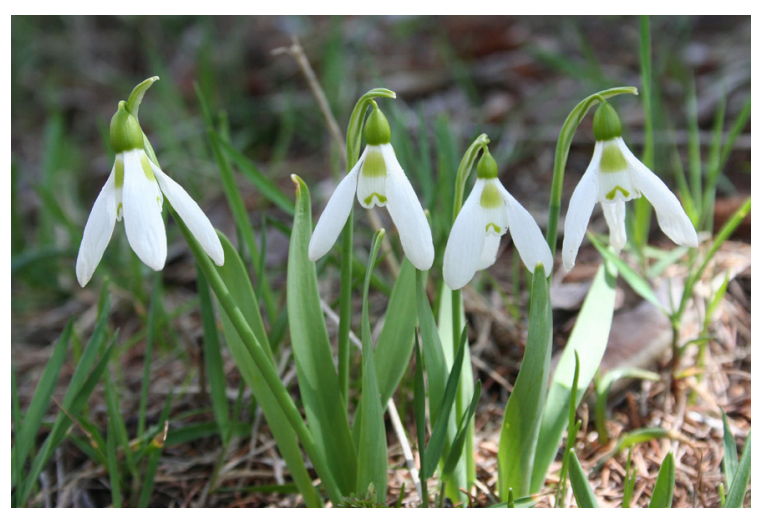

Fig. 76. Galanthus elwesii var. elwesii

Galanthus elwesii Hooker f. var. elwesii (Kardelen) (Fig. 76)

30 cm'ye kadar boylanabilen çok yıllık soğanlı bitkiler. Yapraklar darca ters-mızraksı. Çiçekler beyaz renkli. Meyve geniş̧̧e elipsiodden küresele kadar değişen kapsül. Bu varyete, yetişme ortamı olarak 900-1800 m yükseklikler arasındaki kayalık alanları, çam ve ardıç ormanlarını tercih etmektedir. Ülkemiz dışında Bulgaristan ve Kuzey Yunanistan'da da yayılış göstermektedir. ÇBFCB.

Familya: Araceae (Yılanyastığıgiller)

\section{Dracunculus vulgaris Schott (Yılanbıçă̆ı) (Fig. 77)}

$1.5 \mathrm{~m}$ veya daha fazla boylanabilen tuberli çok yıllık bitkiler. Yapraklar uzun saplı; segmentler mızraksı. Çiçek durumunu çevreleyen spata 20-50 cm boyunda, yeşilimsi, koyu mor veya morumsu kahve renkli. Çiçek durumu $22-40 \mathrm{~cm}$ boyunda ve spata ile hemen hemen aynı boyda. Üzümsü 


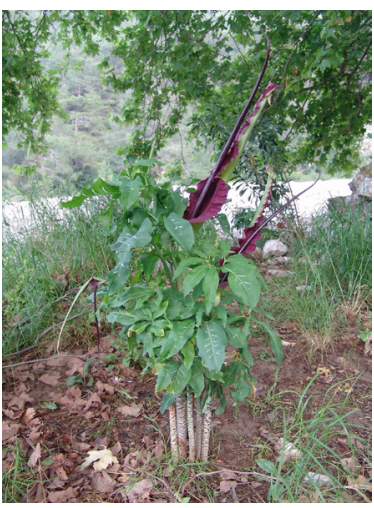

Fig. 77. Dracunculus vulgaris

Üzümsü meyveler portakal-kırmızı renkli. Mayıs ve Haziran aylarında çiçeklenen bu tür, yetişme ortamı olarak 30-475 m’ler arasındaki tarla kenarlarını, ormanlık alanları ve tahrip edilmiş alanları tercih eder. Akd. El.

\section{Familya: Asparagaceae (Kuşkonmazgiller)}

\section{Muscari armeniacum Leichtlin ex Baker (Gavurbaşı)}

Soğanlı çok yıllık bitkiler. Yapraklar 2-7 adet, şeritsi-şeritsi-mızraksı. Periyant segmentleri gök mavisi, mavi renkli. Kapsül meyve genişçe ters yumurtamsı-dairesel. Bu tür yetişme ortamı olarak deniz seviyesinden 2750 m'ye kadar olan yüksekliklerdeki kireçtaşı kayalıklarını, kayalık yerleri, friganayı ve kum tepelerini tercih eder. Çiçeklenme zamanı ise Mart-Temmuz aylarıdır. ÇBFCB.

\section{Muscari muscarimi Medikus (Mis Sümbülü) (Türkiye Endemiği) (Fig. 78)}

2-4 cm çapında soğanlara sahip çok yıllık bitkiler. Yapraklar 3-6 adet, şeritsi-mızraksı. Verimli çiçekler mis kokulu, erken dönemde menekşemsi, daha sonra kirli grimsi-beyaz veya yeşilimsi, kuruyunca kahve renkli. Kapsül meyve geniş. Ülkemize özgü olan bu bitki, Antalya ve Denizli illerinde yayılış gösterir. Mayıs ve Haziran aylarında çiçeklenir ve yetişme ortamı olarak 100-1920 m’ler arasındaki kayalık yerleri, kaya yarıklarını ve step

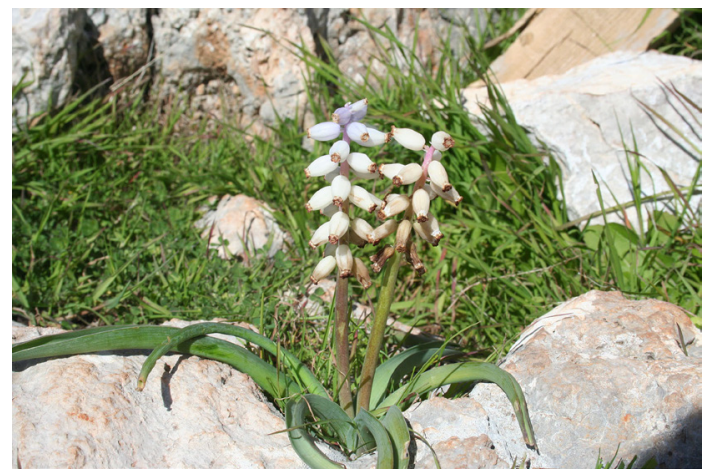

Fig. 78. Muscari muscarimi yamaçları tercih eder. Akd. El.

\section{Ornithogalum montanum Cirillo (Dağ Akyıldızı)}

Çok yıllık soğanlı bitkiler. Çiçek kümesi gövdesi 7-20 cm boyunda. Yapraklar çiçek kümesi gövdesinden kısa. Periyant segmentleri beyaz renkli. Kapsül meyve kanatsız. Mart-Mayıs aylarında çiçeklenen bu tür, yetişme ortamı olarak deniz seviyesinden 1350 m’ye kadar olan yüksekliklerdeki çalııkları, tepelikleri ve çayırlıkları tercih eder. Akd. El.

\section{Ornithogalum umbellatum L. (Sunbala)}

Çok yıllık soğanlı bitkiler. Çiçek kümesi gövdesi dik, 10-30 cm boyunda. Yapraklar şeritsi. Periyant segmentleri beyaz renkli. Kapsül meyve kanatsız. Yetişme ortamı olarak deniz seviyesinden 1500 m’ye kadar olan yüksekliklerdeki tarlaları, nemli çayırlıkları ve çalııkları tercih eder. Çiçeklenme zamanı ise Mart-Mayıs aylarıdır. ÇBFCB.

\section{Scilla bifolia L. (Orman Sümbülü) (Fig. 79)}

Soğanlı çok yıllık bitkiler. Çiçek kümesi gövdesi dik, 5-28(-35) cm boyunda. Yapraklar (1-) 2(-7) adet, genişçe şeritsi. Periyant segmentleri parlak mavi, leylak-mavi veya mavimsi-mor renkli. Kapsül meyve yarı küresel. Ülkemizde oldukça geniş bir yayılış alanına sahip olan bu tür, yetişme ortamı olarak 80-2400 m'ler arasındaki ormanlıkları, kireçtaşı kayalıklarını, erimiş karların kenarlarını tercih eder. Çiçeklenme zamanı ise Şubat-Haziran (Temmuz) aylarıdır. ÇBFCB. 


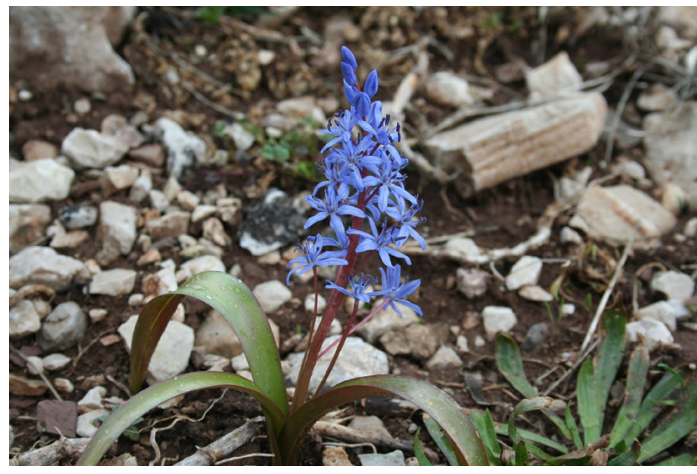

Fig. 79. Scilla bifolia

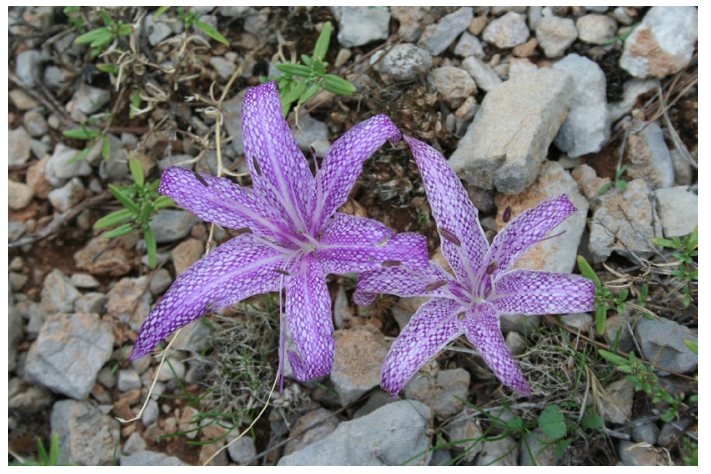

Fig. 80. Colchicum variegatum

Familya: Colchicaceae (Acıçiğdemgiller)

Colchicum variegatum L. (Vargit) (Fig. 80)

Yumurtamsıdan yarı küresele kadar değişen şekillerde korma sahip çok yıllık bitkiler. Yapraklar çiçeklenme zamanında mevcut değil, 3-4 adet, şeritsi-mızraksıdan dilsiye kadar değişen şekillerde. Periyant segmentleri belirgin şekilde damarlı, koyu kırmızı veya menekşe-mor renkli, bazen tabanda soluk veya beyaz renkli. Kapsül meyve dikdörtgenimsi-yumurtamsı. Ülkemiz dışında Yunanistan ve Ege adalarında da yayılış gösteren bu tür, Eylül-Kasım aylarında çiçeklenir. Yetişme ortamı olarak ise 150-1700 m’ler arasındaki kayalık ve taşlık alanları, makilikleri, meşe, funda ve ardıç açıklıklarını çam ve göknar ormanlarını tercih eder. Akd. El.

\section{Familya: Iridaceae (Süsengiller)}

Crocus antalyensis B. Mathew subsp. antalyensis (Antalya Çiğdemi) (Türkiye Endemiği) (Fig. 81)

Çok yıllık kormlu bitkiler. Yapraklar 3-8 adet, çiçeklenme döneminde mevcut. Periyantın boğazı sarı renkli, segmentler leylak-mavi renkli. Stilus 612 parçalı, turuncu-sarı renkli. Kapsül meyve silindirikten elipsoide kadar değişen şekillerde. İlk kez 1991 yılında Antalya'dan toplanarak B. Mathew tarafından bilim dünyasına tanıtılan bu çiğdem, Şubat ve Mart aylarında çiçeklenir. Yetişme ortamı olarak 800-1200 m'ler arasındaki seyrek meşe ormanlarını ve çalııkları tercih eder. Akd. El.

\section{Crocus chrysanthus (Herb.) Herb. (Sarı Çiğdem)} (Fig. 82)

Çok yıllık kormlu bitkiler. Yapraklar 3-5(-6) adet, çiçeklenme döneminde mevcut. Periyantın boğazı sarı renkli, segmentler sarıdan turuncuya kadar değişen renklerde. Stilus 3 parçalı, turuncu ya da sarı renkli. Kapsül meyve silindirikten elipsoide kadar değişen şekillerde. Ülkemiz dışında Balkanlar ve doğu Romanya'da da yetişen bu çiğdem tü-

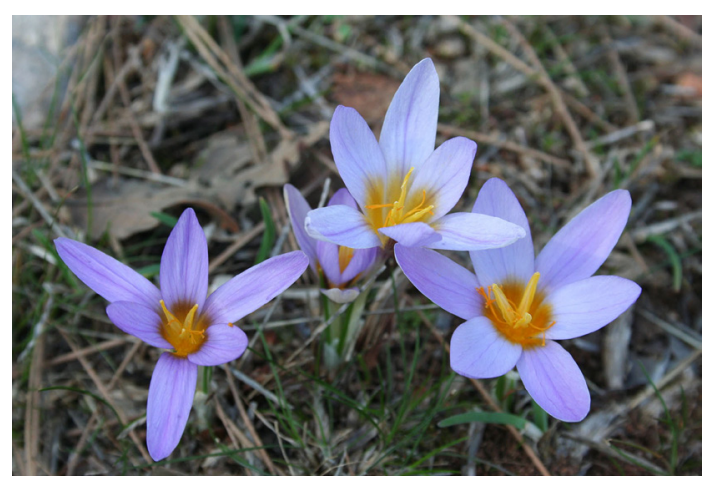

Fig. 81. Crocus antalyensis subsp. antalyensis

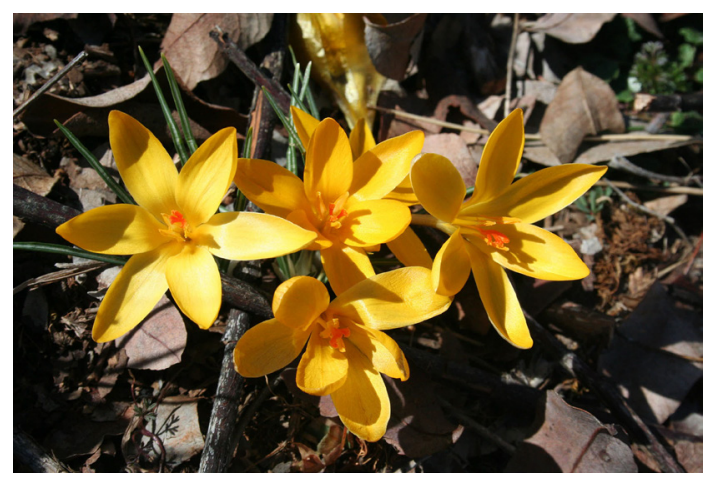

Fig. 82. Crocus chrysanthus 
rü, Şubat-Nisan (Temmuz) aylarında çiçeklenir. Yetişme ortamı olarak ise deniz seviyesinden 2200 m’ye kadar olan yüksekliklerdeki çalııkları, açık tepelikleri ve seyrek konifer ormanlarını tercih eder. ÇBFCB.

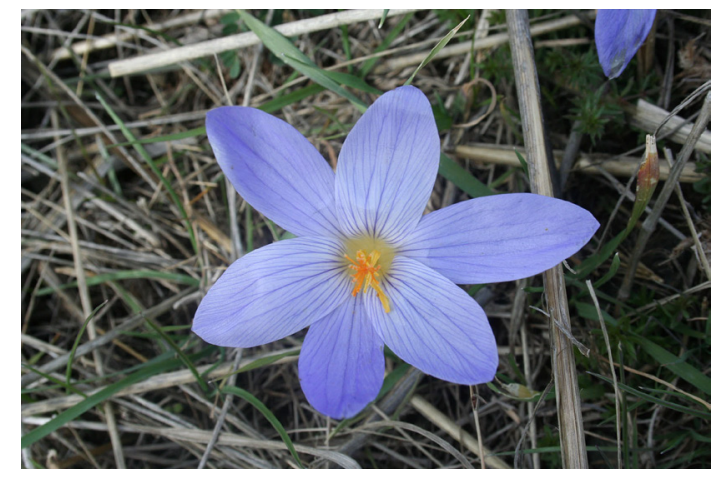

Fig. 83. Crocus speciosus subsp. speciosus

Crocus speciosus M. Bieb. subsp. speciosus (Çayır Çiğdemi) (Fig. 83)

Çok yıllık kormlu bitkiler. Yapraklar 3-4 adet, çiçeklenme döneminde mevcut değil. Periyantın boğazı beyaz renkli, segmentler mavi veya leylakmavi. Stilus çok parçalı, turuncu renkli. Kapsül meyve silindirikten elipsoide kadar değişen şekillerde. Ülkemiz dışında Kırım, Kafkasya ve Kuzey İran'da yetişen bu alt tür, yetişme ortamı olarak 800-2350 m'ler arasındaki ormanlıkları ve çayırlık alanları tercih eder. Çiçeklenme zamanı ise (Eylül)

Ekim-Kasım aylarında çiçeklenir. ÇBFCB.

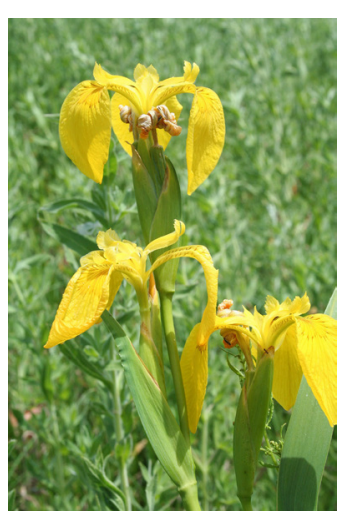

Fig. 84. Iris pseudacorus

\section{Gladiolus italicus Mill. (Kılıçotu)}

Çok yıllık kormlu bitkiler. Gövde 25-70 cm boyunda. Yapraklar (3-)4-5(-6) adet. Periyant soluk pembe morumsu-kırmızı veya kiremit kırmızısı renkli. Anterler 12-16 boyunda. Kapsül meyve ters yumurtamsı. Ülkemizin büyük bir bölümünde yayılış gösteren bu tür, Şubat-Haziran (Temmuz) aylarında çiçeklenir. Yetişme ortamı olarak deniz seviyesinden 1650 m'ye kadar olan yüksekliklerdeki kumul alanlarını, nemli yerleri, kayalık yamaçları ve tahrip edilmiş alanları tercih eder. ÇBFCB.

\section{Iris pseudacorus L. (Bataklık Süseni) (Fig. 84)}

1.5 m’ye kadar boylanabilen sağlam yapılı rizomlu çok yıllık bitkiler. Gövde 1-2 dallı, her dal 1-3 çiçekli. Yapraklar kılıçsı. Çiçekler sarı renkli, kahve renkli işaretli. Kapsül meyve silindirik. Nisan ve Mayıs aylarında çiçeklenen bu bataklık süseni, yetişme ortamı olarak deniz seviyesinden 1200 m'ye kadar olan yüksekliklerdeki bataklıkları, göl kenarlarını ve tatı su kenarlarını tercih eder. ÇBFCB.

\section{Romulea bulbocodium (L.) Sebast. \& Mauri} var. crocea (Boiss. \& Heldr.) Baker (Fig. 85)

Kormlu çok yıllık bitkiler. Yapraklar en fazla 7 adet, 5-15 cm boyunda. Periyant sarı renkli, dış kısmı ise kahve renkli çizgili. Meyve kapsül. Yetişme ortamı olarak deniz seviyesinden 1500 m'ye kadar olan yüksekliklerdeki, orman açıklıklarındaki sabit tepeleri tercih eden bu varyete Şubat-Haziran aylarında çiçeklenir. Bu bitki, ülkemizde sadece Antalya, ülkemiz dışında ise sadece Batı Suriye'de yayılış göstermektedir. Akd. El.

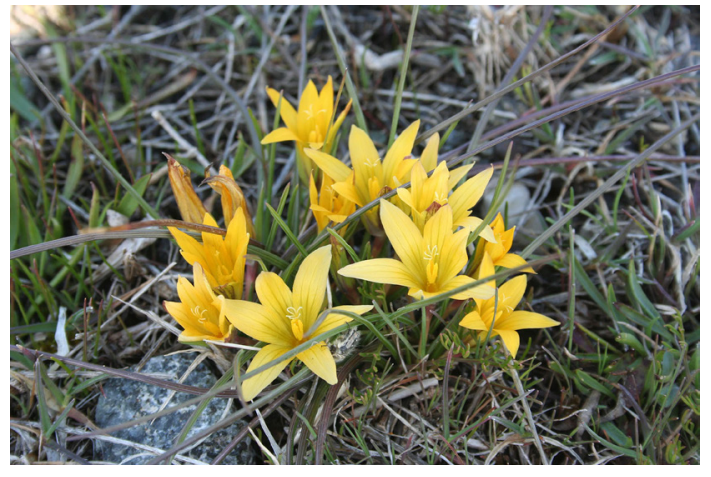

Fig. 85. Romulea bulbocodium var. crocea 


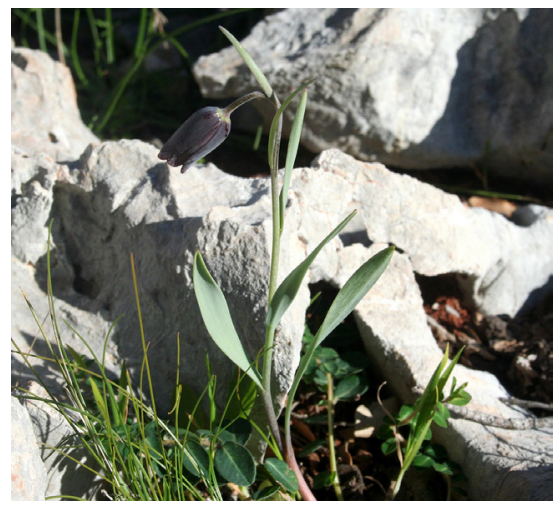

Fig. 86. Fritillaria asumaniae

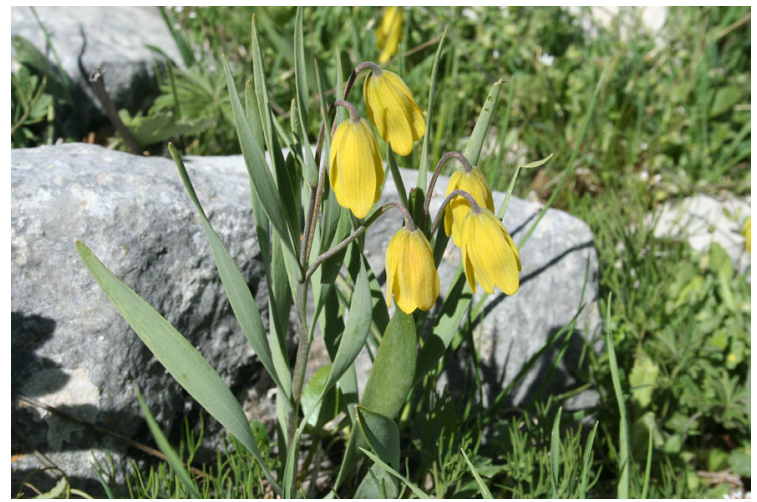

Fig. 87. Fritillaria carica

Familya: Liliaceae (Zambakgiller)

Fritillaria asumaniae R. Wallis, R. B. Wallis \& N. Özhatay (Ters Lale) (Olimpos-Beydağları Milli Parkı Endemiği) (Fig. 86)

Soğanlı çok yıllık bitkiler. Gövde 25-60 cm boyunda. Yapraklar 4-5 (-7) adet, şeritsi- mızraksı. Periyant segmentleri koyu kahverengi-siyah renkli. Kapsül meyve kanatsız. Olimpos-Beydağları Milli Parkına özgü olan bu ters lale, 2015 yılında bilim dünyasına tanıtılmış olup, yetişme ortamı olarak 225-500 m'ler arasındaki kızılçam ormanlarını ve kayalık yerleri yerleri tercih eder. Çiçeklenme zamanı ise Mart-Mayıs aylarıdır. Akd. El.

\section{Fritillaria carica Rix (Bodursarı) (Türkiye Endemiği) (Fig. 87)}

Soğanlı çok yıllık bitkiler. Gövde 3-15 cm boyunda. Yapraklar altta 6-10 adet, darca mızraksı. Periyant segmentleri sarı renkli. Kapsül meyve kanatsız. Ülkemize özgü olan bu ters lale, yetişme ortamı olarak 200-1500 m'ler arasındaki kızıçam ve karaçam ormanlarını, kayalık yerleri özellikle kireçtaşlı kayalık yerleri tercih eder. Çiçeklenme zamanı ise Mart-Mayıs aylarıdır. Akd. El.

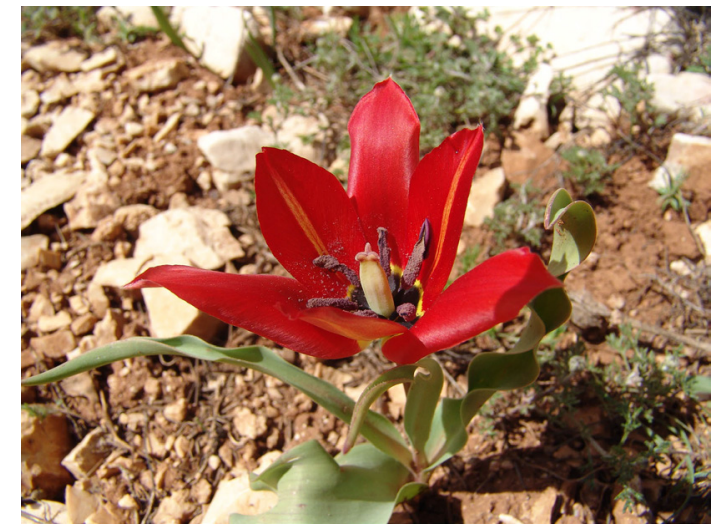

Fig. 88. Tulipa armena var. armena

\section{Tulipa armena Boiss. var. armena (Dağ Lalesi)} (Fig. 88)

Çok yıllık soğanlı bitkiler. Yapraklar 3-4 adet, kenarları genellikle dalgalı ve geriye kıvrık. Çiçekler kırmızı, açık kırmızı, koyu kırmııı, pembe veya sarı ya da hem sarı hem de kırmızı renkli. Kapsül meyve yumurtamsıdan elipsoide kadar değişen şekillerde. Gösterişli çiçeklere sahip olan bu lale Nisan-Haziran aylarında çiçeklenir ve yetişme ortamı olarak 100-2300 m'ler arasındaki kayalık-taşlı yamaçları, nemli çayırlıkları ve orman açıklıklarını tercih eder. Ir.-Tur. El.

Familya: Orchidaceae (Salepgiller)

\section{Anacamptis pyramidalis (L.) Rich. (Sivri Salep) (Fig. 89)}

80 cm'ye kadar boylanabilen yumrulu bitkiler. Yapraklar şeritsi-mızraksı. Başak çiçek durumu çok ve yoğun çiçekli. Brakteler dar mızraksı. Çiçekler koyu veya açık kırmızımsı-pembe, nadiren beyaz renkli. Sepaller yumurtamsı-mızraksı. Labellum 6-9 mm boyunda. Mahmuz ipliksi. Yetişme ortamı olarak deniz seviyesinden 1750 m’ye kadar olan yüksekliklerdeki makiliklerdeki ve frigana 


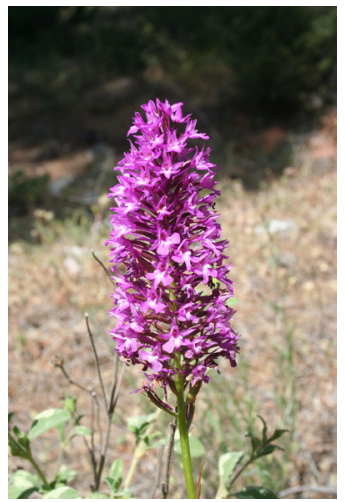

Fig. 89. Anacamptis pyramidalis

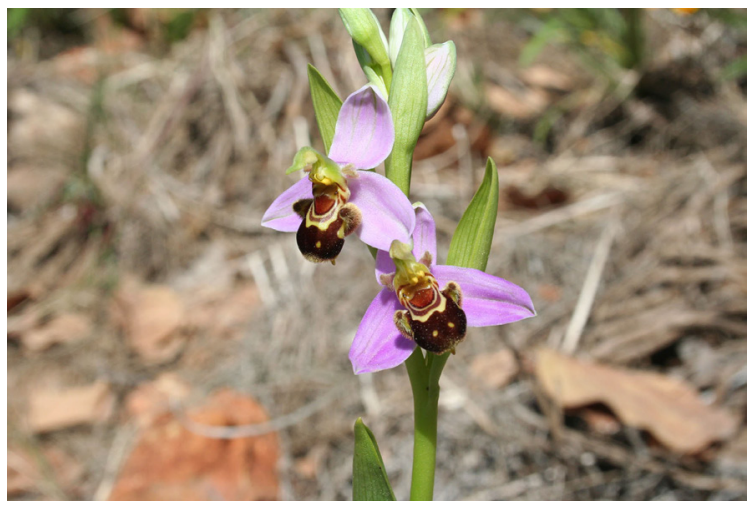

Fig. 90. Ophrys apifera

daki kayalık yamaçları, kalkerli ve şistli toprak alanları, çayırlıkları ve zeytinlikleri tercih eden bu tür, Nisan-Haziran(-Temmuz) aylarında çiçeklenir. ÇBFCB.

Ophrys apifera Huds. (Arı Salebi) (Fig. 90)

20-50(-70) cm boyunda toprakaltı yumrulu çok yıllıklar. Yapraklar genellikle tabanda. Çiçekler 38(-14) adet. Sepaller geniş, dikdörtgenimsi, menekşe-gül veya beyazımsı renkli. Petaller yeşilimsi veya morumsu, kadifemsi. Labellum 3 loplu; lateral loplar koyu kırmızı-kahverenkli, kadifemsi; spekulum kalkancık şeklinde sarımsı kenarlı, taban kısmı kırmızı-kahverengi. Deniz seviyesinden 750 m’ye kadar olan yüksekliklerdeki kireçtaşlı çimenlik tepelikleri, makilikleri, friganayı, çayırları, yol kenarlarını, kozalaklı ve yaprak döken ormanları ve mezarlıklar- yetişme ortamı olarak seçen bu tür, (Nisan) Mayıs-Haziran aylarında çiçeklenir. ÇBFCB.

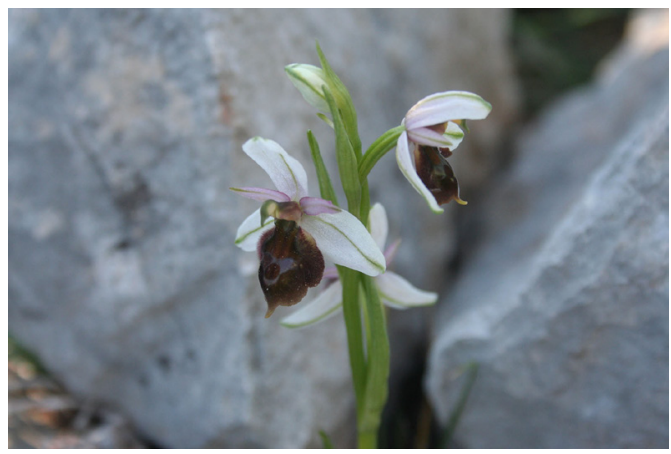

Fig. 91. Ophrys argolica subsp. lucis

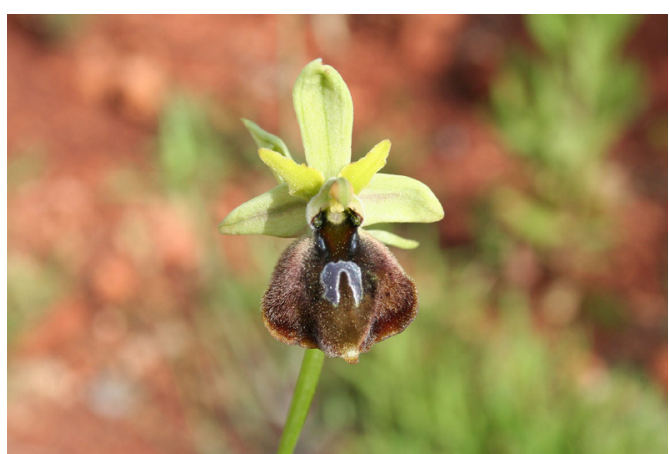

Fig. 92. Ophrys climacis
Ophrys argolica H. Fleischm. subsp. Iucis (Kaltesein \& H. R. Reinhard) H. A. Pedersen \& Faurh. (Rodos Salebi) (Fig. 91)

$30 \mathrm{~cm}$ 'ye kadar boylanabilen, toprakaltı yumrulu çok yıllık bitkiler. Çiçek durumu 2-4 çiçekli. Sepaller mızraksı, beyazımsı, pembe veya açık kırmızımsı. Petaller mızraksıdan yumurtamsı-mızraksıya kadar değişir, kırmızımsı. Labellum 11-13 mm, geniş 3 loplu. Bu alt tür ülkemizde, Antalya ve Mersin illerinde yayılış göstermektedir. Yetişme ortamı olarak deniz seviyesinden 1000 m'ye kadar olan yüksekliklerdeki makilikleri, friganayı, çam, meşe ve servi ormanlarını ve kalkerli toprakları tercih etmekte olan bu alt tür, Mart ve Nisan aylarında çiçeklenir. Akd. El.

\section{Ophrys climacis Heimeier \& Perschke (Antalya} Endemiği) (Fig. 92)

Narin yapılı, $15-40 \mathrm{~cm}$ boyunda, toprakaltı yumrulu çok yıllık bitkiler. Çiçek durumu seyrek 4-6 çiçekli. Sepaller yumurtamsıdan dikdörtgenimsi-yumurtamsıya kadar değişen şekillerde, açık zeytin yeşili-soluk sarımsı renkli. Petaller sarımsı-yeşil 
renkli, yumurtamsı-mızraksıdan dikdörtgenimsi-mızraksıya kadar değişir. Labellum tam kenarlı veya belirsiz 3 loplu. Mart ve Nisan aylarında çiçeklenen bu tür, 1200 m’ye kadar olan çam ve servi orman açıklıklarını, kalkerli toprakları ve çimenlik alanları tercih eder. Akd. El.

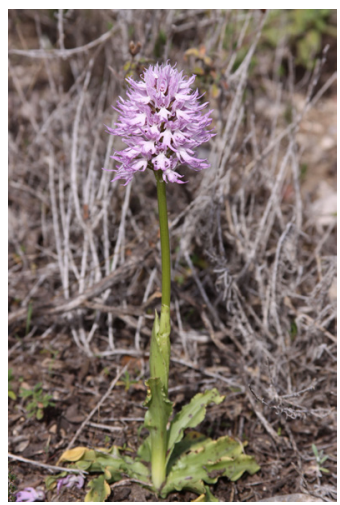

Fig. 93. Orchis italica

\section{Orchis italica Poir. (Teketaşağı) (Fig. 93)}

30 cm'ye kadar boylanabilen yumrulu çok yıllık bitkiler. Yapraklar tabanda 6-10 adet, dikdörtgenimsi-yumurtamsı. Çiçek durumu küreselden konike kadar değişir. Sepal gül renkli, damarlı veya koyu benekli. Labellum 15-20 mm, derin 3 loplu, beyazımsı gül renkli üstte çok sayıda benekli; bütün loplar mızraksı. Mart ve Nisan aylarında çiçeklenen bu orkide türü, 50-700 m’ler arasındaki çimenlik alanlarda ve makiliklerde yetişir. Akd. El.

\section{Familya: Poaceae (Buğdaygiller)}

\section{Briza minor L. (Küçükzembil)}

25 cm'ye kadar boylanabilen bir yıllık otsu bitkiler. Gövde yaprakları seyrek ve 2-4 mm eninde. Çiçek durumu seyrek. Başakçıklar 20-100 tane, genişçe yumurtamsı-üçgensi. Kavuzlar yatay, açılırken dairemsi. Dış kavuz 4-5 adet, tüysüz. Karyopsis meyve genişçe yumurtamsıdan elipsoide kadar değişir. 250 m'ye kadar olan yükseklilerdeki, çayırlıklarda, serpantin alanlarda, çalılıklarda ve meşe ormanı kenarlarında yetişen bu tür, Mayıs ayında çiçeklenir. ÇBFCB.

\section{Cynodon dactylon (L.) Pers. var. dactylon (Köpekdişi)}

Rizomlu, çok yıllık bitkiler. Çiçekli gövde dik veya yayılıcı, yaklaşık $30 \mathrm{~cm}$ boyunda. Yaprak ayası şeritsi-mızraksı. Başak çiçek durumu 2-4 adet. Kavuzlar şeritsi-mızraksı. Dış kavuz yumurtamsı-mızraksı. Nisan-Eylül ayında çiçeklenen bu bitki, 1830 m’ye kadar olan yüksekliklerdeki kuru taşlı tepeliklerde, bataklık ve kumul tepeliklerinde, stepte, nemli yerlerde ve yol kenarlarında yetişir. ÇBFCB.

\section{Lolium rigidum Gaudich var. rigidum (Sert Çim)}

80 cm'ye kadar boylanabilen bir yıllık otsu bitkiler. Yaprak ayası düz ve çıplak. Başak çiçek durumu düz veya kıvrık. Üst kavuz mızraksıdan dikdörtgenimsiye kadar değişen şekillerde. Dış kavuz mızraksı, 3-5 damarlı. Ülkemizde geniş bir yayılış alanına sahip olan bu varyete, Nisan-Temmuz aylarında çiçeklenir ve 1850 m’ye kadar olan yüksekliklerdeki kayalıklarda, stepte, çayırlıklarda, plajlarda ve yol kenarlarında yetişir. ÇBFCB.

\section{Setaria glauca (L.) P.Beauv. (Sıçansaçı)}

20-100 cm boyunda, bir yıllık otsu bitkiler. Yaprak ayası şeritsi. Çiçek durumu dik başak benzeri bileşik salkım. Başakçıklar iki çiçekli. Karyopsis meyve dikdörtgenimsi veya eliptik. 1000 m’ye kadar olan yüksekliklerdeki, nemli yerlerde, tarlalarda ve bahçelerde yetişen bu tür, Temmuz-Ekim aylarında çiçeklenir. ÇBFCB.

\section{Familya: Typhaceae (Sazgiller)}

\section{Typha domingensis Pers. (Şeytan Mumu)}

2 m'ye kadar boylanabilen sağlam yapılı rizomlu bitkiler. Yapraklar uzun şeritsi, 4-14 mm eninde. Çiçekler bir eşeyli, silindirik koçanlarda, üsttekiler erkek alttakiler dişi; dişi koçanlar 6-42 cm boyunda; erkek koçanlar 12-38 cm boyunda. Meyve açılan tipte, iğ biçimli. Yetişme ortamı olarak deniz seviyesinden 1300 m'ye kadar olan yüksekliklerdeki bataklıkları, gölleri, arkları ve nehir yataklarını tercih eden bu tür, Haziran-Kasım aylarında çiçeklenir. ÇBFCB. 


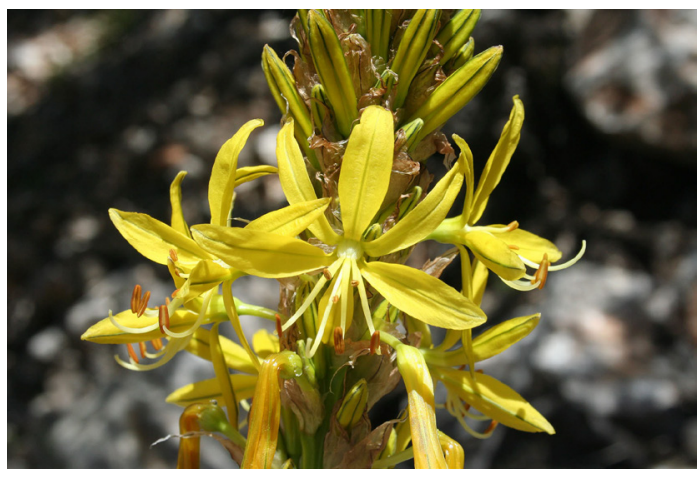

Fig. 94. Asphodeline lutea
Familya: Xanthorrhoeaceae (Çirişgiller)

Asphodeline lutea (L.) Rchb. (Sarı Çiriş) (Fig. 94)

1.5 m'ye kadar boylanabilen çok yıllık otsu bitkiler. Yapraklar çok sayıda, şeritsi. Periyant segmentleri sarı renkli. Kapsül meyve yumurtamsı veya dikdörtgenimsiden küresele kadar değişen şekillerde. Illk kez Sicilya adasından toplanarak bilim dünyasına tanıtılan bu tür, yetişme ortamı olarak deniz seviyesinden 1650 m'ye kadar olan yüksekliklerdeki taşı ve kayalık yamaçları, orman açıkıklarını makilik alanları ve çalılıkları tercih eder. Çiçeklenme zamanı ise Mart-Haziran aylarıdır. Akd. El.

Eremurus spectabilis M. Bieb. (Çiriş) (Fig. 95)

2 m'ye kadar boylanabilen çok yıllık otsu bitkiler. Yapraklar geniş şeritsi, çıplak. Periyant segmentleri beyaz veya yeşilimsi sarı renkli. Kapsül meyve küresel ve buruşuk. Mayıs-Temmuz aylarında çiçeklenen bu tür, yetişme ortamı olarak 1000-2750 m’ler arasındaki stebi, çalı açıklıklarını ve kireç taşı kayalıklarını tercih eder. Ir.-Tur. El.

\section{Sonuç ve Tartışma}

Phaselis Antik Kenti'nde 2012-2016 yılları arasında gerçekleştirilecek proje kapsamında, 2014-2015 yıllarında yapılan arazi çalışması sonucunda 61 familya'ya ait 168 cins ve toplam 203 takson tespit edilmiştir. Son dört yılda (2012-2015) tespit edilen toplam takson sayısı ise 436'dır. Bu 436 taksonun 320 tanesi tür, 77 alt tür ve 39 tanesi ise varyete kategori-

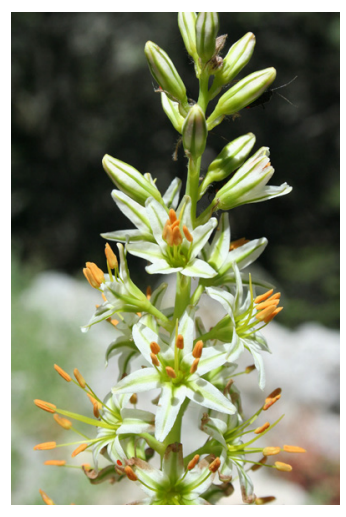

Fig. 95. Eremurus spectabilis sinde yer almaktadır. 2014-2015 yıllarında tespit edilen 203 taksonun 32 (\%15,7) tanesi endemiktir. Bu 32 endemik taksonun 1 tanesi Olimpos-Beydağları Milli Parkı endemiği, 8 tanesi Antalya endemiği ve 23 tanesi de Türkiye endemiğidir. Son dört yılda (2012-2015) tespit edilen toplam endemik takson sayısı ise 62'dir. Bu 62 endemik taksonun 11 tanesi Olimpos-Beydağları Milli Parkı endemiği, 18 tanesi Antalya endemiği ve 33 tanesi ise Türkiye endemiğidir. 203 taksonun 88 tanesi Akdeniz Fitocoğrafik Bölgesi elementi, 10 tanesi İran-Turan Fitocoğrafik Bölgesi elementi, 8 tanesi Avrupa-Sibirya Fitocoğrafik Bölgesi elementi ve 97 tanesi ise Çok Bölgeli veya Fitocoğrafik Bölgesi bilinmeyendir. Son dört yılın sonunda teşhis edilen 436 taksonun 224 tanesi Akdeniz Fitocoğrafik Bölgesi elementi, 12 tanesi İran-Turan Fitocoğrafik Bölgesi elementi, 11 tanesi Avrupa-Sibirya Fitocoğrafik Bölgesi elementi ve 189 tanesi ise Çok Bölgeli veya Fitocoğrafik Bölgesi bilinmeyendir. Dört yıl yapılan çalışma sonucunda Akdeniz Fitocoğrafik Bölgesi elementlerinin 224 tane ile ilk sırada yer aldığı görülmektedir. Bu durumu araştırma alanın tümüyle Akdeniz Fitocoğrafik Bölgesi içinde yer alması ile açıklayabiliriz. Avrupa-Sibirya Fitocoğrafik Bölgesi elementleri ve İran-Turan Fitocoğrafik Bölgesi elementleri ise alanda belirgin şekilde az sayıda yer aldığı görülmektedir. Bunun nedenini ise bu iki fitocoğrafik bölgenin karakterlerini yansıtan habitatların alanda sınırlı olması ile açıklayabiliriz. Bu dönemde çalışma alanında takson sayısı açısından en zengin ilk 5 familya ve takson sayıları şu şekildedir; Lamiaceae 23, Asteraceae 19, Fabaceae 14, Caryophyllaceae 11 ve Plantaginaceae 7. 
Göktürk 2015

Tüner-Önen 2008

\section{BİBLIYOGRAFYA}

R. S. Göktürk, "Phaselis Antik Kenti Florası I". Phaselis I (2015) 81-131.

N. Tüner-Önen, Phaselis Antik Kenti ve Teritoryumu. Yayımlanmamış Doktora Tezi, Akdeniz Üniversitesi. Antalya 2008. 